\title{
THE POLITICAL ECONOMY OF ENTITLEMENT
}

\author{
David A. Super*
}

Debates over "entitlements" have lacked conceptual clarity because the term has at least six analytically distinct meanings. The psychological "entitlements" that many attack are distinct from the legalistic "entitlements" that others champion. Most importantly, however, entitlements are economic concepts. A benefit provided to all claimants meeting stated eligibility requirements can be termed a "responsive entitlement"; its antithesis is a program that arbitrarily caps participation. Similarly, a program whose benefits are defined by the amount required to accomplish some specific purpose is a "functional entitlement"; it may be juxtaposed with one providing only an arbitrary sum. The market through which public sentiments and claimants' needs govern the generosity of benefits and the number of recipients served can be described in terms of familiar supply and demand functions. Responsive entitlements allow that market to clear. Artificially capping participation, by contrast, creates the same inefficiencies economists decry in pricecontrolled markets. Benefits lacking functional entitlements also may distort private markets. Moreover, entitlements are crucial to maintaining political transparency. Without them, programs'scope, benefits, and eligibility requirements must be described in arbitrary terms few voters can comprehend. Voters tend to assume programs are entitlements, overestimating the support available to those programs' target populations. Confusion among types of entitlements, and the complexity inherent in nonentitlements, further impedes meaningful debate. Recognizing this, some liberals have sought to avoid debate about costs by creating nonentitlements that they can slowly expand. Conversely, some opponents of means-tested programs have shifted from attacking programs' funding to dismantling responsive and functional entitlements.

\section{TABLE of Contents}

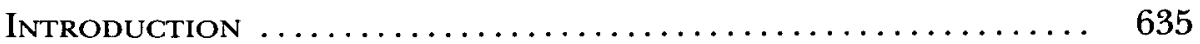

I. A Taxonomy of Entitlements ................... 640

A. Six Types of Entitlement ................. 640

I. Subjective Entitlement $\ldots \ldots \ldots \ldots \ldots \ldots \ldots \ldots, 640$

2. Unconditional Entitlement ............... 644

3. Positive Entitlement ................... 648

* Visiting Professor of Law, Washington \& Lee University. This work benefited from the tireless research of Meri O. Triades and Melanie Coleman. The author is grateful to Helen Hershkoff, David Millon, David Partlett, Dorothy Rosenbaum, and Daniel Tenny for their helpful suggestions on earlier versions of this work. The author also appreciates comments received during presentations of this work before the faculties of the law schools at the American University, Seton Hall University, the University of Maryland, the University of Minnesota, the University of Pennsylvania, the University of Virginia, and Washington \& Lee University. The author is deeply indebted to Stuart Naifeh for his expert editorial guidance. The author also would like to thank the Frances Lewis Law Center of Washington \& Lee University Law School for its generous support of this research. 
4. Budgetary Entitlement ................. 652

5. Responsive Entitlement ................. 654

6. Functional Entitlement .................. 655

B. Some Spurious Definitions of "Entitlement" ....... 658

1I. The Economics of Entrtlements .................. 659

A. Modeling the Market for Means-Tested Benefits ..... 660

1. The Basic Structure of Responsive Entitlements... 661

2. Determining the Generosity and Conditionality of Benefits........................... 668

B. The Relative Efficiency of Entitlement Structures .... 672

1. The Efficiency of Responsive Entitlements ...... 672

a. Waiting Lists and Priority Systems ........ 673

b. Covert Eligibility Restrictions ............ 676

c. Additional lnformation Costs and Administrative Burdens................. 677

d. Common Reasons for Eschewing a Responsive Entitlement .......................... 677

2. The Efficiency of Functional Entitlements ....... 678

3. The Particular Inefficiency of Block Grants ...... 680

4. Types of Programs Rationally Run as

Nonentitlements ...................... 682

a. Instrumental Programs ................. 683

b. Federalism Concerns ................. 684

C. Responsive and Functional Entitlements' Impact on Programs' Policy Goals ........................... 686

1. Incentive Effects ........................ 686

2. Targeting Effects ..................... 689

D. Macreconomic Effects of Responsive Entitlements ... 690

E. Conclusion .............................. 691

Ill. The Politics of Entitlements................... 692

A. Positive Entitlements and Democratic Legitimacy ..... 693

B. The Innate Lack of Transparency of Nonentitlement Programs ................................ 695

1. Responsive Entitlements ................... 696

2. Functional Entitlements .................... 701

3. Unconditional Entitlements ................. 704

4. The Aggregate Political Effect of Nonentitlement Programs .......................... 705

5. The Impact of Combining Responsive and Functional Entitlements ................. 706

C. Political Distortions Resulting from Confusion About Entitlements ............................ 709

1. Manipulation of Varying Definitions of "Entitlement" ............................... 709

2. Obscuring Policy Through Devolution ........ 710 
D. Recent Political Struggles over Entitlements: MeansTested Public Benefit Programs ..................

1. The Traditional Values-Based Model of Public

Benefits Debate .......................... 712

2. Attacks on Entitlement Programs ........... 716

3. Liberals' Quixotic Approach to Entitlement ..... 721

E. Transparency and Legitimacy in Public Benefit

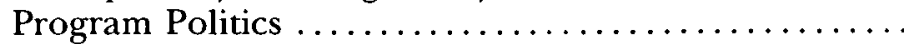

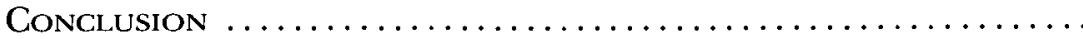

\section{lNTRODUCTION}

Social historian Michael Katz has noted that the term "entitlement" once "signified the solidarity of an expansive welfare state that extended the rights and meaning of citizenship" but by the 1990s had "bec[o]me a term almost as negative as "welfare." Although his characterization is probably a fair generalization about contemporary American debates over entitlements, this topic has provoked a remarkable degree of inconsistency across the political spectrum.

Looking back on the circumstances that led to passage of the 1996 welfare law, ${ }^{2}$ four prominent House Republicans declared that

Because recipients were guaranteed payments regardless of their behavior, entitlement policy permitted or even encouraged dependent behavior such as nonwork and nonmarital births. Moreover, as long as recipients had a legal right to benefits, it would be impossible to create the type of reciprocal welfare system conservatives wanted to establish.

Republicans saw clearly that entitlement blocked all serious steps toward creating a system based on work and individual responsibility. Hence the entitlement to cash welfare had to end. ${ }^{3}$

In a similar vein, the budget the Bush Administration released in February 2004 proposed to replace the individual entitlement to Medicaid with a block grant to states and similarly proposed to block grant some or all of several other important programs for low-income people,

1. Michael B. Katz, The Price of Citizenship 324-25 (2001) [hereinafter Katz, Citizenship]. "Entitlements plus the interest on the debt that our deficits demand are acting like 'pacman:' gobbling up everything in the federal budget, so that soon there will be nothing left to address people's nonentitlement needs," according to Robert Denham of the Bipartisan Commission on Entitlement and Tax Reform. John K. Mahoney, Quick Action on Entitlements Needed to Avert Fiscal Calamity: Gradual Policy Cbanges Now Will Avoid Draconian Cuts in the Future, Nation's Cities Wkly., Dec. 12, 1994, at 14 (quoting Denham) (internal quotation marks omitted).

2. Personal Responsibility and Work Opportunity Reconciliation Act of 1996 (PRWORA), Pub. L. No. 104-193, 110 Stat. 2105.

3. Nancy L. Johnson, Bill Archer, E. Clay Shaw, Jr., \& J. Dennis Hastert, Welfare Reform Has Already Achieved Major Successes: A House Republican Assessment of the Effects of Welfare Reform 8-9 (1999) (on file with the Columbia Law Review). 
including housing assistance, child welfare services, and Head Start. ${ }^{4}$ The Bush budget also proposed broad "superwaiver" authority to override federal standards in numerous programs.

Other conservatives downplay the importance of entitlements. For example, the Heritage Foundation's Robert Rector, a key outside architect of the Personal Responsibility and Work Opportunity Reconciliation Act of 1996 (PRWORA), declared that "eliminating entitlement status alone is not reform, or even a small part of reform. The impact of eliminating the entitlement nature of [Aid for Families with Dependent Children (AFDC)] has been greatly overrated." ${ }^{5}$

Still other conservatives, such as the Hudson Institute's Anna Kondratas, a former senior official in the Reagan and first Bush Administrations, find some value in programs structured as entitlements. Kondratas urged that " $[\mathrm{s}]$ tates might consider whether [not] renouncing the individual entitlement status of Food Stamps[ ] might not better serve their purposes" than a block grant, ${ }^{6}$ and she praised the food stamp program's moderating the effects of recessions. ${ }^{7}$

Yet although many conservatives have criticized and sought to dismantle some entitlements, the rhetoric of entitlement remains attractive to them. Most obviously, President Bush selected a name for his education initiative that mentioned only entitlement-"No Child Left Behind"-without any reference to its subject matter. ${ }^{8}$ And both Republicans and many Democrats have eagerly embraced sweeping business subsidies structured as entitlements within the tax code. ${ }^{9}$

Liberals, too, have taken widely varying approaches to the question of entitlement to means-tested public benefits. ${ }^{10}$ Some see entitlements

4. OMB, Budget of the U.S. Government, Fiscal Year 2005, at 148-49, 154-55, 185 (2004) [hereinafter 2005 Budget]. House Republicans, although not the Bush Administration, also proposed to give five states the option to convert the food stamp program to a block grant. Personal Responsibility, Work, and Family Protection Act of 2003, H.R. 4, 108th Cong. $\$ 602$ (proposing amendment to Food Stamp Act of 1977).

5. Robert Rector, Heritage Found., Backgrounder No. 1075, Yet Another Sham Welfare Reform: Examining the NGA Plan 7 (Mar. 18, 1996), available at http:// www.heritage.org/research/welfare/bg1075.cfm (on file with the Columbia Law Review). The National Governors' Association's 1996 welfare reform proposals, to which Rector refers, served as the basis for PRWORA. See id. at 1 (noting initiation of congressional hearings on NGA proposal).

6. Anna Kondratas, Reflections on National Welfare Policy and State Reform Options 9 (Feb. 1, 1996) (unpublished manuscript on file with the Columbia Law Review).

7. Id. at 6-7.

8. George W. Bush, No Child Left Behind (2001), available at http://www. whitehouse.gov/news/reports/no-child-left-behind.pdf (on file with the Columbia Law Review).

9. See infra note I99.

10. As discussed infra notes 53-54 and accompanying text, the political debate over entitlements has focused with particular intensity on means-tested programs-programs in which eligibility or benefit levels are inversely related to claimants' income and sometimes resources-even though many of the largest entitlement programs are not means-tested (e.g., Social Security and Medicare). 
as representing fundamental moral principles. Senator Daniel Patrick Moynihan declared that PRWORA "terminates the basic Federal commitment of support for dependent children ... putting those children at risk with absolutely no evidence that this radical idea has even the slightest chance of success." 11

Others, however, studiously avoid discussing entitlement in moral terms. Robert Greenstein, director of the Center on Budget and Policy Priorities and a leading opponent of PRWORA, wrote a thirteen-page paper in 1995 criticizing proposals to convert the food stamp program into a block grant without ever mentioning "entitlements." 12

Obviously, the term "entitlement" has become highly emotionally charged. Periodically, we are told that present and future budget deficits can be blamed on the cost of "entitlements." 13 More broadly, we are told that the "culture of entitlement" threatens our very social fabric. ${ }^{14}$ Yet in each of these contexts and many others, it is far from clear that the speakers and their audiences share a common understanding of what an "entitlement" is. ${ }^{15}$

11. 142 Cong. Rec. 20,900 (1996); see also, e.g., Peter Edelman, Searching for America's Heart 140 (2001) (decrying PRWORA for creating a situation in which "no state had any federally defined obligation to help needy children").

12. Ctr. on Budget \& Policy Priorities, Should the Food Stamp Program Be BlockGranted? (June 25, 1995) [hereinafter Food Stamps].

13. "Like a weed run rampant, entitlement programs are taking over the Federal budget, and unless they are brought under control, politicians and economists agree, no hope exists for lowering the deficit in the long run." David E. Rosenbaum, Editorial, Answer: Cut Entitlements. Question: But How?, N.Y. Times, June 8, 1993, at A22.

14. See, e.g., Dave Anderson, Changing a Culture of Entitlement into a Culture of Merit, CPA J., Nov. 2002, at 16, 16 (noting that characteristics of the culture of entitlement include situations in which " $[\mathrm{m}]$ anagers no longer require[ 1 results and corporations stop[ ] demanding performance as a condition for keeping a job or getting a raise"); Marilyn Gardner, Will the "Culture of Entitlement" Give Way to the Age of Humility?, Christian Sci. Monitor, Mar. 6, 2002, at 13 (criticizing the current sense of entitlement, describing the "prevailing credo" as "[d] own with humility and fairness, up with privilege and power").

15. Consider, for example, Professor Law's suggestion that the elimination of the entitlement to cash assistance has contributed to low-income women entering the sex trade. Sylvia A. Law, Commercial Sex: Beyond Decriminalization, 73 S. Cal. L. Rev. 523, 607-08 (2000). Because several things happened at once to cash assistance programs in 1995-1996, it is unclear to which of them she is referring. She may be saying that lowincome women no longer feel secure in the availability of cash assistance and hence feel great pressure to find an alternative source of income for their families, even one they would prefer to avoid. This is certainly plausible because of the supercharged antiwelfare rhetoric of this period. But if this is the problem, the solution need not be legislative. Alternatively, she may be referring to the new conditions being imposed upon the receipt of cash assistance, such as time limits and work requirements. If so, a possible response would be to modify those rules, leaving the basic structure of the program unchanged. Then again, she could mean the elimination of a legal right to benefits. For this to have affected significant numbers of women's behavior, however, those women must have a way of learning that their legal rights have changed. Finally, she could mean that the women are unable to receive benefits or that the amount of those benefits has shrunk to the point 
To a lawyer, an entitlement is a legally enforceable right. ${ }^{16}$ An entitlement program, then, would be a program that creates legally enforceable rights. ${ }^{17}$ That usage, however, although sensible enough, is generally not what participants in legislative debates have in mind when they attack or defend "entitlements." 18 Since legislative intent is a central element in determining whether a statute creates enforceable rights, ${ }^{19}$ lawyers need to understand what "entitlement" means in public policy debates even if that usage is not their own.

Moreover, defining a public benefit program as an "entitlement" simply because it creates some legally enforceable rights is so broad as to be practically useless. Claimants for benefits in programs funded under Temporary Assistance to Needy Families (TANF) clearly have some statutory rights: For example, recipients cannot be sanctioned for failing to comply with work requirements if they lack child care for preschoolers ${ }^{20}$ and have a right to receive assistance from secular providers when the state elects to contract with religious organizations. ${ }^{21}$ Yet calling TANF an entitlement merely because of these paltry rights, and the few others that may exist, would be plainly absurd. The scope of individual rights that TANF offers is manifestly different from those in Social Security, food stamps, farm price supports, and other programs commonly regarded as entitlements. Thus, even leaving aside legislative and policy debates, some means of distinguishing among types of legal rights is clearly necessary for the concept of entitlement to have any objective value in analyzing public policy problems.

This Article seeks to disentangle these several types of entitlement, considering their consequences separately as well as the relationships

that they no longer suffice to support their families. Here also, more details are needed to clarify the argument.

16. See, e.g., lan Ayres \& Eric Talley, Solomonic Bargaining: Dividing a Legal Entitlement to Facilitate Coasean Trade, 104 Yale L.J. 1027, 1036-39 (1995) (emphasizing the legal enforceability of rights); Darryl K. Brown, Criminal Procedure Entitlements, Professionalism, and Lawyering Norms, 61 Ohio St. L.J. 801, 803 (2000) (identifying requisites of criminal procedure, such as discovery rights, expert witnesses, and jury trials, as entitlements); Matthew Diller, Entitlement and Exclusion: The Role of Disability in the Social Welfare System, 44 UCLA L. Rev. 361, 366 (1996) (emphasizing the importance of legally enforceahle benefits).

17. See, e.g., Cleveland Bd. of Educ. v. Loudermill, 470 U.S. 532, 538 (1985) (finding that where terms of puhlic employment create an "entitlement," employee has a legally enforceable right to job that can be overcome only in accordance with the Due Process Clause).

18. See infra Part I.A.

19. See, e.g., Alexander v. Sandoval, 532 U.S. 275, 286 (2001) ("The judicial task [in determining whether a statute creates a private right of action] is ... to determine whether [the statute] displays an intent to create not just a private right but also a private remedy."); Pennhurst State Sch. \& Hosp. v. Halderman, 451 U.S. 1, 15 (1981) ("The initial question before us, then, is one of statutory construction: Did Congress intend in [the statute] to create enforceable rights and obligations?").

20. 42 U.S.C. $\$ 607(\mathrm{e})(2)(2000)$.

21. ld. $\$ 604 a(e)(1)$. 
among them. Part I begins by distilling six analytically distinct definitions of "entitlement" - as well as a few spurious ones-from the overheated rhetoric that envelopes these issues. It then attempts to identify some consistent relationships among these types of entitlement.

Part II analyzes the economics of entitlements. It begins by presenting an economic model of how benefit programs' rules and participation are determined. It then compares the impacts of entitlement and nonentitlement structures on the administration of those programs, on claimants' incentives, and on the macroeconomy. It finds that many public functions are almost inevitably administered through structures that meet several basic characteristics of an entitlement. It then seeks to develop general principles for determining when entitlement structures are and are not appropriate. It concludes that while some aspects of entitlement are essential for the effective management of many types of public functions and the reliable implementation of political choices, entitlement structures do not necessarily imply liberal, generous, or unconditional benefits. Thus, a central assumption of both liberal and conservative thinking in this area is fundamentally flawed. Indeed, some prescriptions for welfare programs offered by leading conservative critics are indisputably entitlements in some important senses of the word.

Part III explores the political dimensions of entitlement structures. It finds that entitlements are essential to political transparency because they allow programs to be described in terms intelligible to nonexperts. Indeed, it finds that even in the absence of a legal entitlement, political and legal arguments tend to assume one because of the difficulty in describing nonentitlement programs coherently. It finds that both liberals and conservatives have taken advantage of the relative unintelligibility of nonentitlement programs to pursue covert agendas to expand or eliminate programs.

The Article concludes that advocates of means-tested public benefit programs, despite their sometimes intense rhetoric in support of entitlements, have in fact underestimated the political and practical importance of entitlements. Those concerned about low-income people, however much or little they are prepared to spend, should show more caution about allocating those scarce resources to nonentitlement programs.

Although this Article illustrates its arguments primarily with reference to subsidies for low-income people, its analysis is applicable across a wide range of spending programs and tax expenditures. Thus, while critics of some entitlement programs in recent times may have been disproportionately conservative and Republican, other programs-and even the same programs in different eras-have had different constellations of opponents and supporters. The prescriptions here seek to advance a goal that people of good will across the political spectrum should broadly share: to make the most efficient and transparent application of whatever resources society allocates to a given purpose. 


\section{A Taxonomy of Entitlements}

Policy debates about "entitlement" tend to produce more heat than light, in significant part because they start from two fundamentally flawed assumptions. First, scholars and advocates assume that the term "entitlement" has one, clearly defined meaning well known to all parties. Second, both their supporters and their critics tend to assume that entitlements are aberrations largely unique to the world of public benefit programs.

This section demonstrates that the term "entitlement" has several, quite different, meanings. Many programs are entitlements in some senses of the word while not in others. ${ }^{22}$ This section also shows that some of the most important types of entitlement operate in ways familiar from other areas of law and everyday life.

\section{A. Six Types of Entitlement}

At least six definitions of "entitlement" are pertinent to social welfare programs such as those that were central to the 1996 welfare law. ${ }^{23}$ These same categories have close analogues in other spheres of economic and political life. This section labels and describes these types while Part I.B addresses a few additional meanings speakers apparently have in mind when they discuss "entitlements." Because these latter definitions tend to be either general epithets or amalgams of two or more of the primary types discussed here, they are more impediments than aids to cogent analysis.

I. Subjective Entitlement. - One aspect of an entitlement is a subjective feeling of security or self-assurance. From its earliest days, a primary goal of the common law has been to induce a subjective sense of security. ${ }^{24}$ People believing they have rights feel and act differently than those believing their well-being is at the sufferance of others. ${ }^{25}$

On the other hand, subjective entitlement can have a repellant side. When we consider someone arrogant, we may say that "he acts like he is

22. A table accompanying this Article seeks to categorize many major federal programs in this regard. See infra table.

23. Personal Responsibility and Work Opportunity Reconciliation Act of 1996 (PRWORA), Pub. L. No. 104-193, 110 Stat. 2105.

24. See J.H. Baker, An Introduction to English Legal History 13-15, 413 (2d ed. 1979) (describing early common law judges as extending the King's peace into previously lawless countryside).

25. This is important in many contexts far removed from public benefits. Property owners have advantages over renters that go far beyond the explicit terms of their fees. It is not enough that our court system defends the financial interests represented in contracts: We clearly recognize the importance of encouraging people to rely upon the sanctity of contracts. When insurance companies or political leaders ask us to put our faith in their hands, they are seeking to foster a sense of subjective entitlement to fair treatment going well beyond any explicit promises they may be making. 
entitled."26 Subjective entitlement can lead to ingratitude: When someone takes advantage of our generosity without ever giving thanks, we may complain that she is treating us like an entitlement. Parents that foster too strong a sense of subjective entitlement in their children may be said to be spoiling them. More broadly, complaints about perceived subjective entitlements have figured prominently in criticisms of Generation X and in some of the backlash against affirmative action. ${ }^{27}$

Whether or not a given program is a subjective entitlement is a matter of individual perception. ${ }^{28}$ As such, it cannot be directly controlled by legislation, and individuals' perceptions may differ. Nonetheless, legislative and administrative choices, as well as public rhetoric, can contribute to or undermine subjective entitlements. Individual legal rights ("positive entitlements"29) can contribute to subjective entitlements, as can a set of straightforward and relatively non-discretionary program rules. ${ }^{30}$ Perhaps the greatest determinant of whether a benefit becomes

26. See, e.g., Bob Woodward, The Agenda 338 (1994) (describing Democratic Senator Bob Kerrey's condemnation of entitlement programs as reflecting a "corrosive give-to-me, help-me attitude" in which individuals sought to be "protected from the consequences of their own actions").

27. See, e.g., Maryanne George, Affirmative-Action Challenge Has Put U-M on Racial Edge, Det. Free Press, Apr. 15, 1998, at 1A (quoting a Native American student who attributes opposition to affirmative action to "privileged white students [who] have a sense of entitlement to attend a prestigious university"); Harold T. Shapiro, Affirmative Action: A Continuing Discussion-A Continuing Commitment (Oct. 16, 1995), at http:// www.princeton.edu/pr/hts/speeches/9510-affirnative.html (on file with the Columbia Law Review) (describing opponents of affirmative action as opposed to "encourage[ing] inappropriate feelings of group entitlement").

28. The table, infra, therefore does not seek to categorize any program as being or not being a subjective entitlement: In each case, some claimants probably feel an entitlement while others do not. One may reasonably speculate that a much higher percentage of claimants regards Social Security as an entitlement than ever felt that way about Aid to Families with Dependent Children, but proving that would require public opinion surveys beyond the scope of this Article.

29. See infra Part I.A.3.

30. The latter is probably the more important of the two because claimants experience program rules directly. Few public benefits claimants likely are aware of much public benefits litigation. Thus, the mere fact that litigation may be under way cannot by itself contribute to any subjective sense of entitlement. Although claimants have more opportunity to receive an administrative fair hearing over disputed reductions or terminations of benefits than they do to take claims to court, see Goldberg v. Kelly, 397 U.S. 254, 269-71 (1970) (requiring such hearings); 7 C.F.R. $\$ 273.15$ (2003) (describing procedures for such hearings in the food stamp program), even fair hearings play little role in most claimants' lives. For example, only about one in three hundred food stamp households requests a fair hearing each year, and only about one in four of those prevails even in part. See Jerry L. Mashaw, The Management Side of Due Process: Some Theoretical and Litigation Notes on the Assurance of Accuracy, Fairness and Timeliness in the Adjudication of Social Welfare Claims, 59 Cornell L. Rev. 772, 811-15 (1974) (arguing that Goldberg had relatively little impact on AFDC's operation); Robert E. Scott, The Reality of Procedural Due Process-A Study of the Implementation of Fair Hearing Requirements by the Welfare Caseworker, 13 Wm. \& Mary L. Rev. 725, 760 (1972) (same); William H. Simon, The Rule of Law and the Two Realms of Welfare Administration, 56 Brook. L. Rev. 
widely held as a subjective entitlement is the behavior of those dispensing the benefit. Although this behavior can be influenced through numerous forms of public policy, it can be difficult to measure, particularly for those not receiving the benefit. Thus, legislators, senior executive officials, and even the public at large may assume that a benefit is a subjective entitlement for those who are eligible while the intended beneficiaries, who must deal with surly, indifferent office staffs, feel nothing of the kind. ${ }^{31}$ One set of claimants, perhaps those in an area where a program is well administered or those of a favored race or gender, may feel an entitlement to a benefit that feels like a grudgingly dispensed gratuity to others less fortunate. ${ }^{32}$

The desirability of having potential claimants for a government benefit perceive a subjective entitlement to that benefit depends on what kinds of behavior and attitudes one seeks to promote. If one believes a high participation rate serves a broader public purpose, a subjective entitlement can help. ${ }^{33}$ On the other hand, if one views participation in the public program as an unfortunate departure from principles of personal independence, undermining the subjective entitlement can help ensure that most people claim the public benefit only as a last resort. ${ }^{34}$

$777,782-88$ (1990) (finding that fair hearings and other results of procedural due process adjudication did not suffice to empower systematically subordinated claimants); Lucie E. White, Subordination, Rhetorical Survival Skills, and Sunday Shoes: Notes on the Hearing of Mrs. G, 38 Buff. L. Rev. 1, 52-58 (1990) (same); David A. Super, Entitlement, CounterEntitlement, and Disentitlement: The Substantive Consequences of Programmatic Structure (unpublished manuscript on file with the Columbia Law Review) (arguing that fair hearing requirement does little to restrain the power of eligibility workers). To the extent litigation may have contributed directly to the maintenance of a subjective entitlement at all, it likely was primarily through cases requiring agencies to give claimants notices clearly explaining their actions. See, e.g., Buckhanon v. Percy, 708 F.2d 1209, 1211-12 (7th Cir. 1983) (finding that state must provide notices clearly explaining its reasons prior to reducing or terminating AFDC benefits); Eder v. Beal, 609 F.2d 695, 701 (3d Cir. 1979) (requiring state to give beneficiaries advance notice allowing them to plan their affairs before terminating eyeglass coverage in Medicaid). But see Gardebring v. Jenkins, 485 U.S. 415, 425 (1988) (finding that AFDC regulations did not give recipients a right to prior notice of changes in the program rules affecting them); Atkins v. Parker, 472 U.S. 115, 130 (1985) (finding no right to notice of broad changes in food stamp eligibility rules even when those changes require individualized calculations to be put into effect).

31. Frances Fox Piven \& Richard A. Cloward, Regulating the Poor 150-51, 163 (1971).

32. See Susan Tinsley Gooden, All Things Not Being Equal: Differences in Caseworker Support Towards Black and White Welfare Clients, 4 Harv. J. Afr. Am. Pub. Pol'y 23, 23-24, 31 (1998) (finding large disparities in the supportive services eligibility workers provide to white and African-American cash assistance recipients).

33. For example, without a sense of subjective entitlement, residents might dither over whether to "bother" the fire department until a small fire grew to threaten their neighborhood. A strong sense of subjective entitlement to public health services may be crucial to averting epidemics when someone is exposed to dangerous infectious agents such as bubonic plague.

34. Thus, for example, someone who calls the fire department several times a month to get his or her cat out of a tree may be feeling too much subjective entitlement. 
People experiencing a subjective entitlement are more likely to be more assertive when a program operates badly; depending on one's perspective, that may be a good or a bad thing. Voters may reward politicians who give them, or preserve for them, a sense of entitlement in a public service or benefit that they value. Most of the time, however, the subjective entitlement is likely to cause voters to take the benefit for granted, with little inclination to reward anyone for its continued availability. ${ }^{35}$ On the other hand, the lack of a subjective entitlement allows politicians to seek public gratitude when a benefit appears. ${ }^{36}$

Prior to the 1960s, AFDC's administration was so highly discretionary that it likely conveyed no sense of subjective entitlement even to most of those who did receive payments. ${ }^{37}$ Some states distributed AFDC checks in state legislators' offices, presumably to help those legislators win recipients' gratitude and support. Building up a sense of subjective entitlement was an essential precondition to the rise of the welfare rights movement. ${ }^{38}$ This was at least as much a focus of its organizing as any particular material or policy improvements. ${ }^{39}$ On the other hand, to get low-income people to accept the sharp, moralizing messages they wished to convey through the welfare system, social conservatives in the 1990 s argued they had to break down this sense of subjective entitlement. ${ }^{40}$

With benefit programs serving broad segments of the politically powerful middle class, the politics of subjective entitlement are quite different. Those advocating change in a program may seek to undermine the sense of subjective entitlement in that program's benefits to enhance the public's willingness to change the structure of that benefit (presumably to take a more reassuring form). For example, proponents of replacing part of the Social Security defined benefit system with defined contribution individual accounts repeatedly emphasize the existing system's long-term

Sometimes we desire some but not all of the attributes of a subjective entitlement. For example, we want people to feel entitled to call the police whenever they are threatened with or victimized by a crime. Part of the job of the police is to make people feel secure in their homes and walking the streets. On the other hand, we should not feel so entitled that we fail to express appreciation to individual police officers who risk their lives for us. And we should be sufficiently cognizant of the limits of what the police can do that we do not take unnecessary risks, such as loitering after dark under shadowy freeway overpasses.

35. Few mayors, for example, get reelected for continuing to maintain sound fire departments, although some likely are defeated for letting fire protection deteriorate.

36. If people felt an entitlement to a continuous supply of new post offices, courthouses, highway projects, etc., they might consider politicians presumptuous to keep showing up for ribbon cuttings.

37. See, e.g., Dorothy K. Newman et al., Protest, Politics, and Prosperity: Black Americans and White Institutions, 1940-75, at 254-61 (1978).

38. See Piven \& Cloward, supra note 31, at 196-98, 330-38 (attributing the explosive increase in public benefits applications in the 1960 s to changing attitudes among lowincome people).

39. ld.

40. See, e.g., Johnson et al., supra note 3 , at $8-9$. 
actuarial imbalance. ${ }^{41}$ Yet when trying to avoid political damage from having proposed changes in a popular broad-based program, politicians may try to reassure the public that nothing that is being discussed should in any way call into question the subjective entitlement to that program's benefits. Thus, the same congressional Republicans who frequently remind the public of the Social Security system's long-term actuarial imbalance complain bitterly about Democrats' "Medi-scare" tactics in opposition to their proposals to modify Medicare-often neglecting to mention that Medicare faces far worse fiscal difficulties than Social Security. ${ }^{42}$ Bolstering the public's subjective entitlement helps take a program serving the middle class off the political agenda.

2. Unconditional Entitlement. - The term "entitlement" is sometimes used to suggest a benefit that one need not earn or a benefit that is not subject to conditions or reciprocal obligations. ${ }^{43}$ Presumably having an entitlement in the unconditional sense may contribute to the subjective sense of entitlement. ${ }^{44}$

This usage is more rhetorical than technical. In reality, designing an entitlement without at least some reciprocal obligations is all but inconceivable. To begin with, programs generally want to require claimants to cooperate in the eligibility determination process by providing information and possibly appearing for interviews or submitting verification. ${ }^{45}$ Programs also typically want to disqualify those who engage in various kinds of misconduct, creating an implicit condition of good behavior on eligibility for these programs' benefits. ${ }^{46}$

41. See Peter A. Diamond \& Peter R. Orszag, Reducing Benefits and Subsidizing Individual Accounts: An Analysis of the PIans Proposed by the President's Commission to Strengthen Social Security passim (2002), available at http://www.cbpp.org/6-1802socsec.pdf (on file with the Columbia Law Review) (criticizing assertions that privatization plans will "restor[el long-term [fiscal] balance to Social Security").

42. See, e.g., U.S. Senate Republican Policy Comm., Democrats Resurrect "Mediscare" Tactics (1999), at http://www.senate.gov/ rpc/releases/1999/mc030399.htm (on file with the Columbia Law Review).

43. See, e.g., Linda Gordon, Pitied But Not Entitled 288 (1994) (“'Entitlements' has become a code word for undeserved benefits."). See generally Jayne Zanglein, Getting Sometbing for Nothing: Are Employee Benefits an Entitlement or a Gratuity?, 30 Tex. Tech L. Rev. 627, 627-56 (1999) (examining Fifth Circuit cases concerning whether employee benefits are entitlements or are provided at the will of the employer).

44. See Lawrence M. Mead, Beyond Entitlement 1, 46-64 (1986) (criticizing the "permissiveness" of means-tested programs).

45. This may not strictly be true for all public services. Yet even the national parks are available only to those who appear at an entrance during the hours they are open. Fire departments wait for us to call-or neighbors to call on our behalf-and notify them of the existence and location of a fire. More to the point, major means-tested and social insurance benefits all have substantial eligibility determination systems.

46. Some of these disqualifications are explicit; others are not. Even municipal fire protection services are likely to be conditioned on our not having savage dogs patrolling the yard around the burning building and our not having stored large amounts of explosive or poisonous chemicals in that building. 
On the other hand, the extent and nature of the reciprocal obligations that programs impose vary dramatically. Some appear to consider programs with "few" conditions to be entitlements and other programs to be something else. ${ }^{47}$ The subjectivity of this approach obviously contributes to the emotionalism and frequent irrationality of debates about entitlements. It also suggests that programs under attack as inappropriate entitlements may be able to defend themselves simply by publicizing the conditions they already impose on benefits rather than by adding new ones.

Some discussions of entitlement distinguish between the types of conditions imposed on access to a public benefit. ${ }^{48}$ For example, a program that imposes only those conditions that are necessary for the administration of the program might be seen as an entitlement, while programs that require additional behavior to serve some broader social or governmental purpose escape that designation. By this definition, local fire protection services, public elementary and secondary education, public parks, and a number of other basic services would be considered entitlements, although they are seldom described in those terms. Similarly, some federal programs providing in-kind assistance, such as school meals, do not condition eligibility on claimants having taken actions beyond those necessary to operate the programs. ${ }^{49}$ These programs, too, are not commonly described as entitlements, presumably because they have few active opponents.

47. See, e.g., Robert E. Rector, "Work" Bill with Crippling Potential, Wash. Times, Oct. 2, 2002, at A15 (criticizing pending legislation as "reject[ing] the very concept that welfare recipients should be required to earn benefits through constructive behavior" and arguing that "[i]nstead, it would move us back to the old entitlement or 'one-way handout' way of thinking."); Jason Turner \& Robert E. Rector, Heritage Found., Backgrounder No. 1669, Under Senate Bill, Welfare Recipients Who Refuse to Work Would Still Get Cash Benefits (July 18, 2003), available at http://www.heritage.org/research/welfare/ bgl669.cfm (on file with the Columbia Law Review) (describing PRWORA as replacing AFDC's "cash entitlements" with TANF's focus on "reciprocal obligation," in which "aid would no longer be unconditional but would be linked to constructive behaviors").

48. The legal and normative merits of the conditions that the government may impose on public benefits are beyond the scope of this Article. See Kathleen M. Sullivan, Unconstitutional Conditions, 102 Harv. L. Rev. 1415, 1424-25, 1503-05 (1989) (suggesting broad flexibility for the government to impose many types of conditions on eligibility for public benefits).

49. Even here, the story is not perfectly clear. The National School Lunch Act and the Child Nutrition Act do not impose behavioral conditions on individual recipients tbat are not fairly directly related to the operation of these programs. See 42 U.S.C. $\$ \S 1751-1791$ (2000), On the other hand, local administrators in practice have considerable ability to control what goes on in their schools and may use that authority to impose behavioral requirements not authorized by the federal statute. See Heimberger v. Sch. Dist. of Saginaw, 881 F.2d 242, 246 (6th Cir. 1989) (finding that children denied school lunches for alleged misbehavior lack standing to challenge apparent violations of the National School Lunch Act). Also, to the extent they are seen as benefits for providers as well as children, they do impose some behavioral requirements. See, e.g., 42 U.S.C. $\$ 1766$ (a) (5) (requiring child care providers to comply with licensing requirements in order to qualify for meal subsidies). 
The largest and more controversial means-tested programs-food stamps, Medicaid, Supplemental Security Income (SSI), and the former AFDC program-all include significant reciprocal obligations on claimants that go far beyond anything plausibly required to administer the programs. ${ }^{50}$ Social insurance programs such as Old Age, Survivors' and Disability Insurance (OASDI, commonly referred to as "Social Security"), Medicare, veterans' compensation, and unemployment compensation impose at least an obligation of contribution on the claimant (or one of her or his close relatives) ${ }^{51}$ and often other eligibility conditions as well.

In practice, when critics assail "entitlements" for their failure to impose reciprocal obligations on claimants, they typically are referring to the major means-tested programs, ${ }^{52}$ not social insurance programs, even though both impose extensive conditions. ${ }^{53}$ These critics implicitly either ignore means-tested programs' requirements of current work-related activity-paid work, job search, participation in job-related training activities, or unpaid workfare ${ }^{54}$-or value them far less than the requirements

Other programs do not impose reciprocal obligations on the federal level but allow states to do so. See, e.g., id. $\$ \$ 8621-8628$ a (giving states broad flexibility to determine eligibility for Low-lncome Home Energy Assistance Program (L1HEAP) benefits).

50. See, e.g., 7 U.S.C. $\$ 2015$ (d), (i), (1), (m), (n) (2000) (disqualifying individuals or households from food stamps for failure to comply with work, child support enforcement, or other behavioral requirements); 42 U.S.C. $\$ \$ 1396 \mathrm{u}-1$ (b) (3), 1396k(a) (1) (authorizing states to disqualify adults from Medicaid for failure to comply with cash assistance programs' work requirements or to cooperate with child support enforcement); id. $\$ 1382 \mathrm{c}(\mathrm{a})(3)(\mathrm{J})$ (disqualifying blind and disabled persons from SSI if substance abuse is a significant contributing factor to their disabilities); id. $\$ 602(a)(19),(26),(44)$ (1994) (repealed 1996) (disqualifying individuals from AFDC for failure to comply with work requirements or cooperate with child support enforcement).

51. See, e.g., 42 U.S.C. $\S \S 402(a)(1)$, (b) (1), (c) (1), (d) (1), (e)(1), (f)(1), (g) (1), (h) (1), (i), 414, 423(a) (1) (A), (c) (1) (establishing contribution requirements for OASDI).

52. See, e.g., Amy L. Wax, A Reciprocal Welfare Program, 8 Va. J. Soc. Pol'y \& L. 477, 485-86 (2001).

53. Alone among the largest means-tested benefit programs, the Earned Income Tax Credit (EITC) generally avoids condemnation as an entitlement in the "unconditional" sense of the word. Presumably this is because it is, by definition, limited to those with earnings. Yet apart from that restriction, it is largely free of the behavioral requirements that constrain claimants for other means-tested benefits. But see 26 U.S.C. $\S 32$ (c) (3) (B) (iii) (Il) (2000) (requiring claimants to "care[ ] for [a foster child] as the taxpayer's own child" in order to treat an otherwise claimable foster child as a "qualifying child" for purposes of calculating the EITC).

54. Contrary to modern rhetoric portraying it as a "hammock" for lazy recipients, see, e.g., Turner \& Rector, supra note 47, at 1, AFDC was one of the most heavily conditioned federal benefit programs. Long before the $1990 \mathrm{~s}$, claimants for AFDC could be disqualified for failing to comply with a host of behavioral requirements, including compliance with job search, workfare, or other work requirements; failure to cooperate with efforts to establish paternity and enforce child support obligations; failure to live with persons of a specified familial relationship; striking; and more prosaic forms of presumed misconduct. 42 U.S.C. $\$ \S 602(a)(19),(21),(26),(43),(44), 606(a), 607$ (1994) (repealed 1996); Johnston v. Iowa Dep't of Human Servs., 932 F.2d 1247, 1249-50 (8th Cir. 1991) (upholding sanction for failure to register for work against a family whom the state never asked to do so). Under waivers the Bush and Clinton Administrations granted in the early 
of past work in the social insurance programs. Imputing non-reciprocity into the term "entitlement," however, has allowed critics of means-tested programs to distinguish between those programs, on the one hand, and those for which eligibility depends on the work history of the claimant or a close relative of the claimant. Thus, even though SSI and OASDI operate similarly in most respects-indeed, both involve significant redistributions of income-polemics attacking "entitlements" for their supposed lack of conditionality or mutuality typically ignore OASDI.

Moreover, the more nearly unconditional programs-smaller public benefit programs and an array of public services-also oddly often escape condemnation as entitlements. This suggests that applying the term entitlement to mean "unconditional" benefit is multiply misleading: Not only is unconditionality a relative rather than an absolute state, but it also implies a benefit whose worth exceeds some fairly significant threshold and a rather subjective grading of what conditions are meaningful. Indeed, even the process of assigning a worth to a benefit is rather subjective. ${ }^{55}$

It would be tempting to dismiss the concept of an "unconditional entitlement" as a thinly disguised epithet with no real substantive meaning. Yet although it often is applied capriciously or inaccurately, it does clearly convey something of genuine significance. The notion of an exchange of obligations is essential to our basic economic and political theories. It is hardly surprising that many voters are more comfortable giving benefits in trade for work or other behavior ${ }^{56}$ - even if they regard the trade as an unequal one-than they would be giving what they regard as quite valuable benefits for nothing at all. ${ }^{57}$

1990 s, AFDC claimants also could be disqualified for failing to ensure that their children attended school, for failing to get their children immunized, or simply for being a child conceived by a woman receiving AFDC. Katz, Citizenship, supra note 1, at 90-100. The fact that particular AFDC claimants were not required to take more specific actions as conditions to receiving aid was far more the result of states' diffidence about operating work and child support enforcement programs than of any rights claimants had under the program's structure.

55. Among other things, the cost of interventions to address acute crises seems less likely to receive scrutiny than responses to chronic problems. For example, the public cost of extinguishing one small domestic fire, to say nothing of rescuing one beleaguered climber from a mountain in a national park, likely far exceeds the typical monthly food stamp, SSl, or cash assistance benefit. The cost of "emergency" agricultural subsidies could fund the expansion of Medicaid to many uninsured low-income parents, yet the cost of the two interventions are rarely compared even when Congress enacts farm "emergencies" several years in a row.

56. See, e.g., Editorial, Reforming the Reforms, N.Y. Newsday, May 17, 2002, at A36 ("The simple genius of welfare reform was the insistence that people work in exchange for government checks.").

57. The fact that critics of programs may apply the term inappropriately suggests that those programs' defenders have several possible strategies available to them: Add conditions to a benefit, reduce the value of the benefit to the point that the public becomes more comfortable providing it unconditionally, better publicize the conditions already attached to the benefit, or better publicize how meager the benefit actually is. The 
The government has two major alternatives to a (relatively) unconditional entitlement. First, it could bind itself to provide aid on the condition that claimants take specified actions. The model here would be a bilateral contract. This contractual model is common in the imagery of conservative critics of means-tested programs. ${ }^{58}$ Alternatively, the government could refuse to make any commitment to provide aid but insist that if it does so, it will only be to claimants meeting certain conditions. PRWORA adopted this barter model. ${ }^{59}$ Whether the contractual or barter model is preferable depends on one's primary complaint against a program providing relatively unconditional benefits. If the concern is to get claimants to take the specified actions-perhaps look for work or perform unpaid labor-a system of mutual obligations will produce the most results. 1f, on the other hand, the concern is that the program is dispensing too much aid, then the barter model is a logical response: lt reduces the number of people receiving aid while leaving the door open to further reductions, even at the expense of people willing to meet the specified conditions. ${ }^{60}$

3. Positive Entitlement. - An "entitlement" also can be a legally enforceable individual right. ${ }^{61}$ This is the meaning of the term, denoted a "positive entitlement," that is probably most familiar to attorneys. ${ }^{62} \mathrm{lt}$

relative strengths and weaknesses of these strategies are discussed below. See infra notes 292-298 and accompanying text.

58. See generally Mead, supra note 44 .

59. Compare 42 U.S.C. $\$ 607$ (e)(1) (2000) (denying benefits to persons who refuse to work), with id. $\$ 601$ (b) (disavowing any commitment to provide benefits even to individuals who are willing to work).

60. As explained infra Part II, this barter approach-at least if it involves capping participation in the program-is nonetheless likely to be quite inefficient.

61. Entitlements also can vest rights in other entities, such as states or businesses. Indeed, some operate only with the joint actions of individuals and some larger corporate entity. For example, Medicaid benefits are only payable if both a state elects to participate and an eligible individual applies for benefits. This article will limit its discussion of positive entitlements to those that accrue to individuals in jurisdictions that have made whatever election is required to make that program available.

62. The current legal academic literature also focuses heavily on positive entitlements. See, e.g., Timothy S. Jost, Disentitlement 23 (2003) (arguing that legal rights in Medicare, Medicaid, and health-related tax provisions are fundamental to the provision of health care); Todd G. Cosenza, Preserving Procedural Due Process for Legal Immigrants Receiving Food Stamps in Light of the Personal Responsibility Act of 1996, 65 Fordham L. Rev. 2065, 2070-72 (1997) (discussing impact of PRWORA on Goldberg $v$. Kelly entitlement analysis); Cynthia R. Farina, On Misusing "Revolution" and "Reform": Procedural Due Process and the New Welfare Act, 50 Admin. L. Rev. 591, 618-23 (1998) (asserting that PRWORA's disclaimer of an entitlement to cash assistance was intended to eliminate private rights of action, not to disclaim the existence of a property interest sufficient to trigger due process scrutiny); Rebecca E. Zietlow, Two Wrongs Don't Add Up to Rights: The lmportance of Preserving Due Process in Light of Recent Welfare Reform Measures, $45 \mathrm{Am}$. U. L. Rev. 1111, 1121-24 (1996) (explaining how welfare rights came to be understood as positive entitlements). Although much of this literature surrounds the 1996 welfare law, it also extends to other benefit programs the government provides. See, e.g., Eleanor D. Kinney, Procedural Protections for Patients in Capitated Health Plans, 22 Am. 
also may be the definition people most commonly have in mind when making moral arguments about society's duties to its less fortunate members. ${ }^{63}$

Under a series of cases in the late 1960s and early 1970s, a program's being a positive entitlement has two specific implications. First, an individual denied benefits for reasons that an entitlement statute does not authorize can sue to require that those benefits be provided. ${ }^{64}$ Second, the rights an entitlement creates are sufficiently choate to constitute a property interest for purposes of the Due Process Clause. ${ }^{65}$ The lion's share of litigation over means-tested public benefits programs has involved efforts to enforce positive entitlements in one of these two ways. ${ }^{66}$

J.L. \& Med. 301, 304 (1996) ("Courts have long recognized that beneficiaries of the Medicare and Medicaid programs have a protected property interest in these programs."). See generally Richard J. Pierce, Jr., The Due Process Counterrevolution of the 1990s?, 96 Colum. L. Rev. 1973 (1996).

63. See, e.g., Gordon, supra note 43 , at 56-60 (describing the debates that led to the creation of AFDC's predecessors).

64. See, e.g., Rosado v. Wyman, 397 U.S. 397, 407-20 (1970) (finding a private right of action for claimants to enforce the state plan requirements in the AFDC statute); King v. Smith, 392 U.S. 309, 333-34 (1968) (holding that statutory provision assuring prompt payment of aid to eligible claimants prohibits states from denying benefits on the basis of criteria not authorized under federal law).

65. Goldberg v. Kelly, 397 U.S. 254, 261-62 \& n.8 (1970) (noting that recipients' interest in continued AFDC benefits was a property right triggering the protections of the Due Process Clause). But see Glen O. Robinson, American Bureaucracy: Public Choice and Public Law 119 (1991) (seeing the derivation of legal entitlements from statutes as a complex process of interpretation rather than a simple deduction); Richard B. Stewart \& Cass R. Sunstein, Public Programs and Private Rights, 95 Harv. L. Rev. 1195, 1257-58 (1982) (suggesting that a plausible version of due process law could be constructed without a formalistically defined concept of legal entitlement).

66. Other meanings are theoretically possible. A positive entitlement could be property protected by the Takings Clause as well as the Due Process Clause. U.S. Const. amend. V. The Court has given no support to this theory. See Bowen v. Gilliard, 483 U.S. 587, 606-09 (1987) (finding no taking in rules denying AFDC to a family based on child support payments legally limited to the benefit of one child notwithstanding argument that this effectively compelled caretaker relative to divert those support payments to the benefit of other family members); Flemming v. Nestor, 363 U.S. 603, 610-12 (1960) (finding no taking in termination of employment benefits). But see id. at 622-23 (Black, J., dissenting) (disputing that conclusion). Similarly, the commitment to provide benefits to identifiable people meeting specific requirements could be, but has not been, seen as a contract protected from abridgement by the Contracts Clause. U.S. Const. art. I, $\S 10$, cl. 1. One could also see the granting of benefits to one person as creating a property interest in all other similarly-situated persons under the Equal Protection Clause. U.S. Const. amend. XIV, $\$ 1$. The Court has rejected any broad application of this principle. See, e.g., Schweiker v. Wilson, 450 U.S. 221, 238-39 (1981) (holding Congress's refusal to grant SSI benefits to individuals in public mental institutions not funded through Medicaid does not violate constitutional guarantee of equal protection); Califano v. Jobst, 434 U.S. 47, 56-58 (1977) (holding that preserving disability benefits for two eligible persons upon marriage while terminating benefits if only one spouse is eligible does not violate equal protection). It remains true, however, that members of a protected class are likely to gain a positive entitlement to a benefit to which they had no other claim once it is provided to similarlysituated persons outside that class. See, e.g., Frontiero v. Richardson, 411 U.S. 677, 690-91 
The legal opposite of a positive entitlement is an entirely discretionary government action ${ }^{67}$ about which an individual has nothing more than a unilateral expectation. ${ }^{68}$

A positive entitlement need not, however, be unconditional or devoid of reciprocal obligations. Before 1996, the right to benefits under AFDC was legally enforceable and recognized as a property right. Even so, AFDC was also subject to numerous categorical, financial, and behavioral conditions. ${ }^{69}$

A positive entitlement's value thus depends on the nature of the underlying program it is protecting. How important is it really that the Spe-

(1973) (finding violation of Equal Protection Clause where military benefits granted unequally on the basis of sex); Graham v. Richardson, 403 U.S. 365, 376 (1971) (finding Equal Protection violation where welfare benefits were discriminatorily denied to aliens). Most broadly, Professor Farina suggests that entitlements could trigger the full panoply of rights Charles Reich envisioned as "the new property." See Farina, supra note 62, at 613-15 (discussing this possible meaning of a positive entitlement along with private rights of action and property rights triggering due process protection); Charles Reich, The New Property, 73 Yale L.J. 733, 783-85 (1964) (arguing that a broader conception of property is essential to the preservation of civil liberties).

67. See, e.g., Heckler v. Chaney, 470 U.S. 821, 835 (1985) (finding FDA had complete discretion whether to take action against production and distribution of dangerous drugs).

68. See Perry v. Sindermann, 408 U.S. 593, 602-03 (1972) (finding that a claimant must have more than a mere subjective expectation of continuation of a governmental benefit in order to have a property interest). This rigid view that the Due Process Clause only applies to deprivations of entitlements is hardly inevitable. See Cynthia R. Farina, Conceiving Due Process, 3 Yale J.L. \& Feminism 189, 265-66 (1991) (advocating a contextualist approach to due process that varies the degree of due process protections to reflect the extent of inequalities in power); Jerry L. Mashaw, Administrative Due Process: The Quest for a Dignitary Theory, 61 B.U. L. Rev. 885, 888-95 (1981) (arguing that due process law ought to vindicate the individual's right to participate in decisions affecting her in important ways without regard to the presence of a positive entitlement); Richard $B$. Saphire, Specifying Due Process Values: Toward a More Responsive Approach to Procedural Protecuion, 127 U. Pa. L. Rev. 111, 139-43 (1978) (arguing Court's premising recognition of due process upon positive guarantee "effectively drains due process of ... its substance as an independent constitutional restraint"); Robert S. Summers, Evaluating and Improving Legal Processes-A Plea for "Process Values," 60 Cornell L. Rev. 1 (1974) (same); see also Frank I. Michelman, Formal and Associational Aims in Procedural Due Process, in Due Process: Nomos XVIIl 126, 132-34 (J. Roland Pennock \& John W. Chapman eds., 1977) (suggesting that positivist definition of rights currently employed by Court implies a "minimalist interpretation of due process"); Henry Paul Monaghan, of "Liberty" and "Property," 62 Cornell L. Rev. 405, 440-41 (1977) (arguing that practice and common social arrangements, as well as state law, plays a part in defining legal entitlements sufficient to receive due process protection); William Van Alstyne, Cracks in the "New Property": Adjudicative Due Process in the Administrative State, 62 Cornell L. Rev. 445, 483-84 (1977) (asserting general right to be free of arbitrary governmental behavior without regard to whether the interests affected can be characterized as entitlements).

69. See supra note 54; see also Jerry L. Mashaw, Due Process in the Administrative State 33-34 (1985) (finding that Goldberg's requirement of administrative fair hearings skewed the organization of public benefit programs in ways disadvantageous to claimants); Simon, supra note 30 , at 787 (same). Similarly, a positive entitlement need not give rise to a subjective one. See supra notes $28-32$ and accompanying text. 
cial Milk Program ${ }^{70}$-providing half-pints to a few hundred thousand children not receiving full school lunches-is a positive entitlement? The value of a positive entitlement also depends considerably on the ease with which claimants can enforce it and the extent of relief available. Rights that a positive entitlement nominally protects can be lost because of rules requiring exhaustion of cumbersome administrative remedies, ${ }^{71}$ rules preventing courts from correcting denials of rights that have taken place before the claimant manages to get to court, ${ }^{72}$ or allowing officials to deny those rights in a substantial number of cases. ${ }^{73}$ Some of the constraints on positive entitlements are program-specific; others cut across all of public benefits law. ${ }^{74}$ Thus, the value of positive entitlements as a group likely has eroded over the past three decades.

On the other hand, the complete absence of a positive entitlement does not necessarily reduce the value of a benefit much if other political or administrative factors will drive the government to continue to provide it. A $\$ 400$ check buys just as much whether the state was legally obliged to write it or simply chose to do so. State and local governments routinely take out and repay loans bound only by their "moral obligation" to do so. ${ }^{75}$ If bondholders can recognize the value in money that a state is likely to pay, and is under great political pressure to pay, so too can claimants for public benefits.

In sum, although a positive entitlement indisputably has value to claimants, it is neither necessary nor sufficient to assure that they will receive meaningful benefits. This may explain why neither supporters nor opponents of PRWORA had much to say about positive entitlements

70. 42 U.S.C. $\$ 1772(2000)$.

71. See, e.g., id. $\$ 405(\mathrm{~g})$, (h) (precluding judicial review of most decisions of the Social Security Administration that have not been rendered final through a multistep administrative process); Bowen v. Mich. Acad. of Family Physicians, 476 U.S. 667, 674-75 (1986) (analyzing limitations on claimants' access to judicial review of adverse decisions in Medicare); cf. 5 U.S.C. $\$ 704$ (2000) (limiting judicial review of federal agencies' actions to final orders).

72. See, e.g., Edelman v. Jordan, 415 U.S. 651, 677-78 (1974) (holding that Eleventh Amendment bars federal courts from ordering restoration of welfare benefits improperly denied in prior periods).

73. See, e.g., Shands v. Tull, 602 F.2d 1156, 1160-61 (3d Cir. 1979) (finding only "substantial compliance" with federal timeliness standards required of state agencies).

74. See, e.g., Green v. Mansour, 474 U.S. 64, 73-74 (1985) (prohibiting even notice relief in federal court where claimants have been unlawfully denied benefits but no violation is ongoing).

75. E.g., Steup v. Ind. Hous. Fin. Auth., 402 N.E.2d 1215, 1218-19 (Ind. 1980) (discussing state appropriations to pay bonds of state authority which the state had no legal obligation to honor); Mass. Hous. Fin. Agency v. New Eng. Merchs. Nat'l Bank, 249 N.E.2d 599, 608-10 (Mass. 1969) (same); Utah Hous. Fin. Agency v. Smart, 561 P.2d 1052, 1056 (Utah 1977) (same); State ex rel. Warren v. Nusbaum, 208 N.W.2d 780, 801-02 (Wis. 1973) (same); Witzenburger v. State ex rel. Wyo. Comm. Dev. Auth., 575 P.2d 1100, 1117-18 (Wyo. 1978) (same). 
in the 1995-1996 debate. ${ }^{76}$ A far subtler analysis of entitlement than some lawyers have customarily offered is needed.

4. Budgetary Entitlement. - An "entitlement" under federal budget process law is a program whose funding level is not ordinarily determined through the annual competitive appropriations process. ${ }^{77}$ Budget process law refers to entitlements more formally as "mandatory" or "direct spending" programs. A formula of some kind written into permanent law typically controls the amount committed to each budgetary entitlement. In some cases, this formula may be as simple as a specified funding level for each year with instructions about how those funds are to be allocated among eligible claimants (e.g., states) ${ }^{78}$ More commonly, however, a budgetary entitlement has eligibility requirements and a formula for determining the amount of benefits written into law or set administratively under criteria specified by law. ${ }^{79}$

Budgetary entitlements are considered "mandatory" spending because they are not conditioned on the enactment of appropriations legislation. ${ }^{80}$ The budgetary opposite of an entitlement or mandatory program is a discretionary program. The laws creating, or authorizing, these programs may contain detailed eligibility requirements and specifications

76. Indeed, while repeatedly disavowing any "entitlement" to benefits funded under the block grant, the TANF statute also suggests (albeit without requiring) that states honor another hallmark of the positive entitlement, the administrative appeal. 42 U.S.C. $\S 602$ (a)(1)(B) (iii).

77. See 2 U.S.C. $\$ \$ 622(9), 65 I(b), 900$ (c) (8), (17) (2000).

78. For example, 42 U.S.C. $\$ 1397$ a gives states a budgetary entitlement to Social Services Block Grants under Title XX of the Social Security Act, with 42 U.S.C. $\$ 1397 \mathrm{~b}$ defining the share each was to receive of the $\$ 2.8$ billion per year Congress designated for the program in the early and mid-1990s.

79. See, e.g., 7 U.S.C. $\$ \S 2012$, 2014, 2015, 2017, 2020, 2025 (2000) (setting out major eligibility, benefit calculation, and administrative reimbursement requirements of the food stamp program).

80. A law creating a budgetary entitlement establishes sufficiently clear legal rights that unsuccessful claimants could successfully sue for benefits in the Court of Claims. For example, should eligible claimants be denied Medicaid assistance due them, they presumably could prevail under the requirement "that such assistance shall be furnished with reasonable promptness to all eligible individuals." 42 U.S.C. $\$ 1396 a(a)(8)$. If no funds appropriated for that program were available, those benefits would be paid from the permanent unlimited appropriation for judgments against the United States. 28 U.S.C. $\$ \S 2414,2517(2000)$. Thus, the law creating those enforceable rights to benefits is an exercise in "direct spending," i.e., no further action is required for the funds to be made available.

This does not, however, mean that positive entitlements and budgetary entitlements are synonymous. Although some positive entitlement generally is required for a program to be a budgetary entitlement, those rights may be held solely by states as is the case in the TANF, SCHIP, and Social Services Block Grants. In these cases, no individual positive entitlement exists. Even where individuals do have positive entitlements, if the program's operation depends in the first instance upon state or local units of government opting to participate-as in the case of Medicaid, food stamps, and the child nutrition programsthen any individual positive entitlement is conditional on those units exercising their options. 
for benefit levels, but they lack any legally enforceable right to benefits. Thus, if appropriations run short, the program must reduce benefits, establish waiting lists, or shut down altogether.

The distinction between mandatory and discretionary programs is important for several reasons. First and most obviously, mandatory programs are generally immune from shortfalls in appropriations resulting from delays in the appropriations process or political impasses. Mandatory programs' advocates thus are less vulnerable to annual political rent-seeking ${ }^{81}$ behavior from legislators, and their inability to meet demands for rents is less likely to result in immediate damage to these programs.

Second, budget process law does not charge spending for mandatory programs against the annual caps imposed on appropriations. This largely eliminates any incentive for appropriators to limit funding for these programs. ${ }^{82}$ Recent presidents and congresses of both parties have found tightening the caps on annual appropriations one of the least painful and contentious ways of reducing spending. ${ }^{83}$ Thus, exemption from these caps can be an important advantage.

Finally, the Budget Enforcement Act of $1990^{84}$ groups mandatory programs together with taxes for purposes of its "pay as you go" requirement. ${ }^{85}$ Thus, an increase in mandatory spending may be offset with a decrease in mandatory spending or an increase in revenues. ${ }^{86}$ Similarly, reductions in entitlements can pay for tax cuts. When Congress is following "pay-go" rules, mandatory programs come under scrutiny when members seek to cut taxes, ratify revenue-reducing trade agreements, or increase spending on other entitlement programs. ${ }^{87}$

While important procedurally, budgetary entitlements are exceedingly difficult to describe in a meaningful way to those not steeped in congressional procedure. ${ }^{88}$

81. See infra text accompanying note 245 .

82. Indeed, some statutes creating mandatory programs contain their own ongoing appropriations, eliminating any occasion to go through the appropriations process. See, e.g., 42 U.S.C. § 603(a)(1)(E) (establishing ongoing appropriation for TANF block grants during the life of their original authorization).

83. E.g., Pub. L. No. 104-19, § 2003, 109 Stat. 194, 247 (1995); Pub. L. No. 103-66, $\S 14002$ (a), 107 Stat. 312, 683 (1993); Pub. L. No. 101-508, § 13111, 104 Stat. 1388, 1388602 (1990).

84. Pub. L. No. 101-508, $\$ \S 13001-13401,104$ Stat. $1388-573,1388-573$ to -628 (codified as amended in scattered sections of 2, 15, 31 \& 42 U.S.C.).

85. 2 U.S.C. $\S 902(2000)$.

86. See, e.g., 2 U.S.C. $\$ 644(\mathrm{~b})(1)(\mathrm{A})-(\mathrm{B}), \quad$ (E) (allowing various budgetary requirements to be met by offsetting changes in revenues and budgetary entitlements).

87. See generally infra Part III.B.

88. See, e.g., 142 Cong. Rec. 18,485 (1996) (statement of Sen. Bradley) (describing a mandatory block grant as "transferring pots of money from one group of politicians to another group of politicians without regard to need, rules or accountability"); id. at 18,488 (statement of Sen. Daschle) ("We are talking for the most part about discretionary programs here that are in large measure underfunded today. ... [I]f they do not have the 
5. Responsive Entitlement. - Many "entitlements" are funded based on the number of eligible people seeking benefits and the amount for which they are eligible. ${ }^{89}$ Funding for these programs therefore rises and falls based on need without any further legislative action. These responsive entitlements promise to meet the needs of all eligible claimants. Thus, a promise to "leave no child behind" 90 is a promise of a responsive entitlement.

The alternative is to cap program expenditures at a fixed amount. ${ }^{91}$ If demand appears likely to exceed available funds, the program's options include reducing benefit levels, establishing waiting lists or other systems for prioritizing claimants, or simply operating the program until it exhausts its funds and then shutting it down.

By definition, programs funded with discretionary appropriations cannot assure claimants of a responsive entitlement. ${ }^{92}$ On the other hand, if appropriations are fully adequate to meet all valid claims in a year, a discretionary program may operate as a responsive entitlement in that year. The Special Supplemental Nutrition Program for Women, Infants, and Children (WIC) is discretionary ${ }^{93}$ but had sufficient funds to serve all eligible claimants for several years prior to the recession of $2001 .{ }^{94}$ To much the same effect, if political reality makes passage of any necessary supplemental appropriation a virtual certainty, a discretionary program effectively becomes a responsive entitlement. ${ }^{95}$

resources, if we do not have the safety net, if they do not have the opportunities to access those programs, then ... they are meaningless.").

89. See, e.g., Rebecca M. Blank, It Takes a Nation: A New Agenda for Fighting Poverty 99 (1997) (describing AFDC as it existed before PRWORA); Joel Handler, The Poverty of Welfare Reform 135 (1995) (comparing AFDC with capped programs that ran out of funds during the Great Depression); Tom Joe \& Cheryl Rogers, By the Few for the Few 17-18 (1985) (discussing New Deal "entitlement" programs).

90. See supra note 8 .

91. In practice, because the number of participants is easier to track and control in most programs than the amount spent on those participants, agencies commonly cap participation at a level that will allow no more than the desired level of expenditures based on projected average costs per recipient.

92. See supra Part 1.A.4. Medicaid funds are subject to appropriations in state legislatures. Although those appropriations sometimes prove inadequate, the alternative to a supplemental appropriation-shutting down the Medicaid program for the remainder of a state's fiscal year-is clearly unthinkable and probably contrary to federal law. See Coalition for Basic Human Needs v. King, 654 F.2d 838, 841 (1st Cir. 1981) (requiring State to pay AFDC benefits even in face of fiscal difficulties); Knoll v. White, 595 A.2d 665, 668-69 (Pa. Commw. Ct. 1991) (finding state obligation to continue paying federally funded public benefits even in absence of state legislative appropriation).

93. See 42 U.S.C. $\$ 1786$ (a) (2000) (limiting WIC spending to the amounts appropriated by Congress).

94. See, e.g., OMB, Budget of the U.S. Government, Fiscal Year 2002, at 110 (2001) (proposing appropriation of $\$ 4.1$ billion to serve 7.25 million people monthly in 2002); $\mathrm{OMB}$, Budget of the U.S. Government, Fiscal Year 2001, at 256 (2000) (proposing appropriation of $\$ 4.1$ billion to fulfill President's goal of "full participation in WIC").

95. For example, food, fuel, ammunition, combat pay, and other necessities for fighting a war are all subject to appropriations, but the Pentagon quite sensibly treats them 
Conversely, some mandatory programs are capped and thus are not responsive entitlements. AFDC's statute included a cap for a few years in the 1960 s when participation was growing explosively. ${ }^{96}$ Since 1977 , the Food Stamp Act has included various types of caps, none of which has ever compelled a reduction in benefits. ${ }^{97}$

Laypeople have enormous difficulty comprehending programs with no responsive entitlement. When told that meeting certain eligibility criteria is a necessary condition to receiving a particular benefit, the public assumes that meeting that criteria is also a sufficient condition. Unfounded assumptions of responsive entitlements permeate legal and policy debates about public benefit programs. ${ }^{98}$ Indeed, even courts adjudicating cases involving discretionary programs strike down state rules rationing benefits on the grounds that some of those found less needy are needy nonetheless. ${ }^{99}$ However noble these sentiments might be, in the absence of a responsive entitlement they largely involve shifting resources from one set of needy claimants to another, possibly less needy one.

6. Functional Entitlement. - Another understanding of entitlement is that it is a guarantee that the program will meet some qualitatively definable need of its beneficiaries. These "functional entitlements" are perhaps more often described as "standards" than as "entitlements." 100 For example, courts, policymakers, and analysts often assume that AFDC benefits provided the minimum amount necessary to sustain a family. ${ }^{101}$ Food stamps are assumed to provide enough to purchase a minimally adequate

as responsive entitlements since it has no doubt it can win passage of any supplemental appropriations it needs.

96. Edelman, supra note 11 , at 72, 79-81.

97. See, e.g., Food Stamp Act of 1977, Pub. L. No. 95-113, § 18(a)-(c), 91 Stat. 958 , 979 (codified as amended at 7 U.S.C. $\$ 2027$ (a) (2000)).

98. See infra Part III.B.1.

99. E.g., Clifford v. Janklow, 733 F.2d 534, 540-41 (8th Cir. 1984) (rejecting state's efforts to reduce benefits in low-income home energy assistance program to claimants receiving federal housing subsidies); Crawford v. Janklow, 710 F.2d 1321, 1327 (8th Cir. 1983) (similarly rejecting efforts to completely exclude claimants receiving federal housing subsidies).

100. See, e.g., 142 Cong. Rec. 18,483 (1996) (statement of Sen. Kerry) (equating denial of food stamps to children with denying them "a minimally nutritious diet"); 141 Cong. Rec. 8501 (1995) (statement of Rep. Kennelly) (opposing proposed child nutrition and child welfare block grants by insisting that in "the School Lunch Program, the elimination of standards put at risk the whole point of the program-providing nutritional meals" and worrying that "the elimination of minimal standards in child welfare programs . . could mean increased numbers of abused children").

101. See, e.g., 142 Cong. Rec. 18,479 (1996) (statement of Sen. Lautenberg) (describing AFDC as a "guarantee that poor children in this country would not starve"); id. at 18,482 (statement of Sen. Mikulski) (similarly assuming that vouchers replacing AFDC benefits would be enough to "ensure that the basic subsistence needs of children are met"). 
diet. ${ }^{102}$ Medicaid is assumed to assure access to necessary health care services. ${ }^{103}$

In fact, none of these assumptions is valid. The AFDC statute vaguely suggested that states should determine how much a family would require to meet its basic needs ${ }^{104}$ but never required states to pay that amount. By the early 1970s, the Supreme Court had made clear that it would not impose such a functional entitlement. ${ }^{105}$ The Food Stamp Act of 1964 did indeed purport to assure households of a minimally adequate diet. When the D.C. Circuit took some tentative steps towards enforcing that requirement, ${ }^{106}$ however, Congress stripped that language from the statute. ${ }^{107}$ In 1985, the Supreme Court disavowed any functional entitlement in Medicaid, holding that states are largely free to deny indisputably necessary services. ${ }^{108}$ Thus, the opposite of a functional entitlement is a

102. See, e.g., John Caniglia, Agents Focus on Store in Huge Food Stamp Fraud Case, Cleveland Plain Dealer, Jan. 14, 2003, at B1 ("The food stamp program is meant to ensure that low-income families and children have a healthy diet."); Howie Carr, Cardinal's Welfare Views Conflict with His Flock, Boston Herald, Oct. 15, 1995, at 10 (arguing that the continued availability of food stamps ensures that children will not be "starving" when cash assistance is terminated).

103. See, e.g., Frank R. Jose et al., Editorial, Health Commitment Must Be Preserved, Seattle Times, Aug. 30, 1995, at B5 (describing Medicaid as having been "established to ensure that all Americans receive necessary health care").

104. 42 U.S.C. $\$ 602$ (a) (23) (1994) (repealed 1996).

105. See Rosado v. Wyman, 397 U.S. 397, 413-15 (1970) (declining to interpret statutory provision requiring states to update AFDC standards of need as compelling them to make those standards adequate).

106. Rodway v. U.S. Dep't of Agric., 514 F.2d 809, 818 (D.C. Cir. 1975) (requiring food stamp program to ensure recipients can obtain "a nutritionally adequate diet"). The Food Stamp Act continues to set benefit levels in a way designed to allow claimants to purchase a particular amount of food, but that diet is adequate only under several quite unrealistic assumptions. See Mary Ellen Natale \& David A. Super, The Case Against the Thrifty Food Plan as the Basis for the Food Component of the AFDC Standard of Need, 25 Clearinghouse Rev. 86, 88-91 (1991) (arguing that the "thrifty food plan" developed by the USDA is nutritionally deficient and is based on faulty assumptions regarding lowincome households' ability to obtain and prepare food). Thus, it remains in part a functional entitlement, but a somewhat defective one.

107. H.R. Rep. No. 95-464, at 246 (1977), reprinted in 1977 U.S.C.C.A.N. 1978, 2191 ("The food stamp program is still a significant nutritional benefit, but is no longer, if it ever was, in and of itself sufficient to provide all the nutrition a participating household should have in order to remain healthy."). Although no longer guaranteed, a functional entitlement to an adequate diet remains the benchmark against which many judge the program. "Even without any of the cutbacks the Reagan Administration plans to make in the Food Stamp Program, the current allotments do not entitle the vast majority of recipients to a nutritionally adequate diet." Marian Burros, Cutting the Food Stamp Program Could Mean Even Poorer Diets for Some, Wash. Post, Feb. 12, 1981, at E1; see also Group Says Food Stamps Don't Assure Good Diet, L.A. Times, Oct. 19, 1985, at 10 (quoting Food Research and Action Center research finding that in major metropolitan areas, a minimally nutritious diet cost $26 \%$ to $54 \%$ more than food stamp allotments provided).

108. Alexander v. Choate, 469 U.S. 287, 303 (1985) ("[T] he benefit provided through Medicaid is a particular package of health care services, . . . not 'adequate health care." ). But see, e.g., Weaver v. Reagan, 886 F.2d 194 (8th Cir. 1989) (requiring state Medicaid 
benefit whose level is set arbitrarily, without regard to the cost of achieving any particular mission or function.

Although relatively rare in public benefits law, ${ }^{109}$ the equivalent of functional entitlements is the norm in numerous other settings. An automobile assembly plant is not simply given a fixed sum with which to purchase wheels (the equivalent of a positive entitlement); it has a functional entitlement to four wheels plus a spare for each car it is building. To be sure, it likely has a budget with which it is expected to obtain the necessary wheels. Whatever the consequences of exhausting that budget may be, however, they do not include sending cars to showrooms without wheels. To the same effect, fire departments offer a functional entitlement to extinguish fully any dangerous fire: No one would suggest that firefighters leave with a house still ablaze at the end of an arbitrary period of time.

A functional entitlement is a definition of what beneficiaries will receive from a program. If that definition is legally enforceable, the program then is also a positive entitlement. If the function the benefit performs is an important one, it may give recipients some sense of subjective entitlement. A functional entitlement need not be a responsive entitlement or a budgetary entitlement; indeed, most probably are not.

A functional entitlement is comprehensible to the layperson without a great deal of programmatic or economic knowledge. Understanding

program to cover AZT for AIDS patients because it is medically necessary); White v. Beal, 555 F.2d 1146, 1151 (3d Cir. 1977) (recognizing broad discretion in distribution of medical services under Medicaid but holding that manner of distribution must bear a rational relationship to the underlying federal purpose of providing services to those in greatest need). Medicaid does provide a functional entitlement for children through its early and periodic screening, diagnosis, and treatment (EPSDT) component. See 42 U.S.C. $\S 1396 \mathrm{~d}(\mathrm{a})(4)$ (B), (r) (2000); see also, e.g., Mitchell v. Johnston, 701 F.2d 337, 349-51 (5th Cir. 1983) (allowing state to deny dental services to children only upon a showing that those services are unnecessary).

109. Designing programs often involves a trade-off between functional and responsive entitlements. With the budget likely to be available to a new program, corners often must be cut either as to how much of a benefit is provided or as to how many people can receive the benefit. Housing assistance programs were designed as functional entitlements-with clear standards about housing quality and affordability. When the supply of unsubsidized low-cost housing shrank dramatically during the last quarter century, these programs lost ground in their effort to assure safe and affordable housing to low-income people. AFDC, on the other hand, operated as a responsive entitlement but handled budget problems by allowing the real value of benefits to shrivel. The result in most states was a responsive entitlement to an arbitrary, grossly inadequate sum of money.

Numerous discretionary programs-those that lack budgetary entitlements-offer functional entitlements. E.g., 42 U.S.C. $\$ \S 1437 \mathrm{a}(\mathrm{a})(1), 1437 \mathrm{~d}(\mathrm{f})$ (capping assisted housing rents at thirty percent of households' income and imposing quality standards). Few, however, purport to provide responsive entitlements. E.g., id. $\$ 1437$ (a) (2) (expressly disavowing any federal conmitment to assure housing for all or even most of those in need). This pattern reflects the fact that it is quicker and easier to reduce the number of people served in response to an appropriations deficiency than it is to scale back the value of the benefit provided. 
the functional significance of an arbitrarily defined positive entitlement, on the other hand, is exceedingly difficult. ${ }^{110}$ This is especially true for persons with little appreciation for the financial and other stresses lowincome people face-including most judges, legislators, and other senior policymakers. ${ }^{111}$ And commentators trying to construct rational arguments about public benefits issues are loath to begin their analyses with the admission that the amount of the benefits whose allocation they are addressing is fundamentally irrational. ${ }^{112}$ It thus is far easier to assume that each program offers a functional entitlement that seems consistent with that program's general area of concern. This understandable but flawed assumption has contributed mightily to misunderstandings about means-tested public benefit programs.

\section{B. Some Spurious Definitions of "Entitlement"}

Some discussions of these programs employ the term "entitlement" informally with a few other meanings. Some critics apply it to meanstested programs generally. ${ }^{13}$ This seems unhelpful with other, more precise terms available for the same purpose. Moreover, as is developed at more length below, ${ }^{114}$ many means-tested programs are entitlements in only a few respects-or none at all. Conversely, the federal government spends far more on non-means-tested programs that are entitlements in most senses of the word than it does on all means-tested programs. ${ }^{115}$

110. Although we comprehend and discuss many positive entitlements-the right to a trial by jury, the right to counsel, etc.-upon close examination the best-understood of these generally are functional entitlements, too. If litigants' legal rights included only a fixed number of hours of jurors' or lawyers' time, only those with some expertise in the conduct of trials could determine what those rights were likely to accomplish.

111. When a court is asked, for example, to overturn a practice that relies on an unlawful attribution of income to reduce families' AFDC benefits, it naturally wants to be able to assert that it has done something more than increase the family's income from one arbitrary, grossly inadequate sum to another. Similarly, when granting food stamp households a more substantial deduction for high shelter costs, members of Congress want to be able to claim they are eliminating, rather than just ameliorating, the conflict between heating and eating. See, e.g., H.R. Rep. No. 97-106, at 257 (1981) (recounting member taking a position "to avoid forcing elderly people to choose between heating or eating"); $\mathrm{S}$. Rep. No. 96-236, at 17 (1979), reprinted in 1979 U.S.C.C.A.N. 939, 955 (suggesting that Senate proposal would prevent elderly people from having to choose between an adequate diet and paying their shelter and medical costs).

112. See, e.g., Andy Sher, Bush Proposes Flexibility for States on Medicaid, Chattanooga Times Free Press, Feb. 1, 2003, at A1 (quoting aide to Senate Majority Leader Frist as saying that Medicaid will "ensure continued access to quality health care").

113. See, e.g., 141 Cong. Rec. 38,110 (1995) (remarks of Rep. Meyers) (vaguely characterizing a variety of means-tested programs as an "entitlement system").

114. See infra table.

115. The Congressional Budget Office projects that the two biggest non-means-tested mandatory programs-Social Security and Medicare-will together spend $\$ 11.5$ trillion of a total of $\$ 18.4$ trillion that the federal government will devote to budgetary entitlements during fiscal years 2005 through 2014. Overall, non-means-tested budgetary entitlements will spend more than three times as much as their means-tested counterparts over this period. See Cong. Budget Office, The Budget and Economic Outlook: Fiscal Years 2005 
Another unhelpful usage of the term "entitlement" is to designate all government benefits whatsoever. When conservative critics of government argue that taxation to fund "entitlements" is improper redistribution of income, they likely have no particular type of program in mind. ${ }^{116}$ Since their concept can readily be captured by generic terms like "public benefits," little analytical purpose is served by applying the term "entitlement" to all such payments in the budget.

Finally, some seem to define entitlements as programs that are not block grants. This meaning certainly can be gleaned from the welfare debates of 1995-1996 and subsequent commentary. Block grants, however, vary considerably, with some (including TANF) qualifying as entitlements under some definitions. Block grants also involve federalism and financial management issues that are quite independent of the question of entitlement or disentitlement. ${ }^{117}$ In recent years, the purpose of block grant proposals often appears to be eliminating either a responsive entitlement ${ }^{118}$ or a functional entitlement. ${ }^{119}$ Thus, it often will be more useful analytically to juxtapose a block grant with the particular type of entitlement it would negate.

\section{The Economics of Entitlements}

Understanding the practical consequences of entitlement and nonentitlement structures can help policymakers improve the efficiency of benefit programs in allocating the scarce funds society makes available to them. Particularly important to this inquiry are the three definitions of "entitlement" advanced in the last section-unconditional, responsive,

to 2014 , at 57 (2004), available at http://www.cbo.gov (on file with the Columbia Law Review).

116. See, e.g., Larry P. Arnn, Claremont lnst., The Meaning of American Citizenship (1997), at http://www.claremont.org/writings/970515arnn.html (on file with the Columbia Law Review) (criticizing other conservatives because "[f] ew oppose entitlements root and branch" as illicit redistributions of wealth). For a more analytical approach to this argument, see Richard A. Epstein, Takings 306-07 (1985).

117. See infra notes $179-186$ and accompanying text.

118. The successful proposal to convert AFDC to a block grant in 1996 and the unsuccessful proposals in 1995-1996 to block grant Medicaid, food stamps, child nutrition, part of SSI, and child welfare services all essentially were efforts to end those programs' responsive entitlements. By transferring substantial authority over the programs to the states at the same time they capped funding, these proposals were less obvious, and less vulnerable to political attack, than simple caps. President Bush's current proposal to give states the option to replace Medicaid with a block grant is similarly in significant part an effort to end Medicaid's responsive entitlement. See OMB, Budget of the U.S. Government, Fiscal Year 2004, at 126-27 (2003) [hereinafter 2004 Budget] (describing President Bush's Medicaid block grant proposal).

119. The failed efforts to block grant child welfare services, child nutrition, and WIC in 1995 would have eliminated functional entitlements in those programs. President Bush's current proposals to create mandatory or state-option block grants in place of Medicaid, Head Start, child welfare services, and Section 8 housing vouchers similarly would eliminate most or all of those programs' functional entitlements. See id. at 126-27, 130-31, 165-66. 
and functional entitlements-that are fundamentally economic concepts. Together, the conditions on, amount of, and availability of a benefit largely determine its economic impact. ${ }^{120}$ This section offers an economic analysis of the impact of designing programs with these three types of entitlement features. ${ }^{121}$ It begins by offering a rigorous economic model for analyzing the way that public preferences and potential claimants' needs dictate the rules and participation in public benefit programs. lt finds that these two functions operate in a manner closely akin to that in which producers' supply curves and consumers' demand curves determine equilibrium prices and quantities in private markets. It then demonstrates how responsive entitlements, and often functional entitlements, foster greater economic efficiency in the same way that free markets most efficiently set the prices of goods and services in the private sector.

From this foundation, this section explores other economic effects of relying upon entitlement structures for public benefit programs. Finally, it considers the circumstances under which nonentitlement structures are more appropriate for public endeavors.

\section{A. Modeling the Market for Means-Tested Benefits}

Many members of Congress who typically espouse market-oriented approaches to public policy issues have become staunchly opposed to programs that operate as open-ended, or responsive, entitlements. ${ }^{122}$

120. The liberality of a program's benefit structure is a function of how much it provides-i.e., whether it is a functional entitlement at all and, if so, how ambitious the functional commitment is-and what one must do to obtain the benefit. In a perfectly commoditized world, one could attach a cost to complying with behavioral conditions and compare that cost to the benefits the program provides. See infra Part III.B.2. From the government's point of view, the cost of a program depends both on how many potential claimants the program screens out with its eligibility conditions and the value of the benefits that it provides to those who do qualify.

121. The two legal types of entitlement described in Part II.A-the lawyer's positive entitlement and the legislator's budgetary entitlement-are important as means of implementing one or another of the economic forms of entitlement. Positive entitlements promote efficiency by ensuring that agreed-upon rules are followed and thus by limiting and focusing policy debates. Budgetary entitlements, in turn, promote efficiency as well as political transparency by limiting opportunities for political rent-seeking. Each, however, has little inherent substantive structure that can be studied.

Psychology certainly plays a role in claimants' and program administrators' behavior; subjective entitlements therefore would be appropriate elements of this analysis. As noted supra Part I.A.l, however, determining which program designs will induce how many claimants to perceive a subjective entitlement is an inexact science at best and requires knowing a great deal about the ground-level administration of a program as well as the public rhetoric surrounding it. A detailed discussion of the role of subjective entitlements is beyond the scope of this article. See David A. Super, Offering an Invisible Hand: The Rise of the Personal Choice Model for Rationing Public Benefits, 113 Yale L.J. 815, 825-32, 836-44 (2004) [hereinafter Super, Offering an lnvisible Hand] (discussing ways of reducing participation in means-tested programs in part by undermining subjective entitlements).

122. E.g., 148 Cong. Rec. H3657 (daily ed. June 18, 2002) (remarks of Rep. Fletcher) (discussing proposals for market-based Medicare prescription drug coverage); 141 Cong. 
Criticism of responsive entitlements led to a cap on food stamp expenditures in the 1995 House welfare bill. ${ }^{123}$ Similarly, it has fed support for converting responsive entitlements to block grants and to designing new initiatives, such as the State Children's Health Insurance Program (SCHIP), ${ }^{124}$ established in 1997, as capped programs.

This strong preference for capped programs is paradoxical. When a program's primary purpose is to serve its recipients, responsive entitlements distribute benefits far more efficiently. This advantage holds without regard to how generous or restrained society wants to be in providing a given benefit. Members who would reflexively oppose price controls in other contexts are supporting very much the same thing when they reject or dismantle uncapped responsive entitlements. In each case, the market's failure to clear leads to serious inefficiencies. ${ }^{125}$

1. The Basic Structure of Responsive Entitlements. - Society's willingness to supply a public benefit and a potential claimant's inclination to seek that benefit can both be reflected as simple functions of the liberality of that benefit. The more people a program serves, the less willing society will be to make that benefit available on liberal terms. Thus, for example, some social service programs that provide counseling or other relatively inexpensive services often have relatively relaxed means tests. A few errors here or there do not arouse great concern. If, however, a program is going to provide more valuable benefits, society is more likely to insist on tougher eligibility conditions. Conversely, the more liberal a benefit isboth in its eligibility conditions and in the benefits provided to those meeting those conditions-the greater potential claimants' demand for those benefits will be.

Figure 1 represents this interaction as a simple pair of supply and demand curves: The vertical axis is the liberality of the benefit and the horizontal axis is participation in the program. Thus, the supply curve descends from top left to lower right and the demand curve climbs from lower left to upper right. The slopes of these curves are reversed from those in more familiar supply and demand diagrams because the "product" here-a public benefit-has a cost to the supplier and a benefit to the consumer. ${ }^{126}$ A responsive entitlement may be defined as a program

Rec. 33,748 (1995) (remarks of Rep. Castle) (defending proposed spending bill for "ending the open-ended entitlement nature of Medicaid").

123. H.R. Conf. Rep. No. 104-430, at 631-32 (1995).

124. 42 U.S.C. $\$ \S 1397 \mathrm{aa}-1397 \mathrm{jj}(2000)$.

125. In traditional economic terms, a market for a good is said to "clear" when the price at which it sells is such that the number of people willing to sell at that price exactly equals the number of people willing to buy at that price.

126. The slopes of the supply and demand curves in this diagram could be returned to their traditional alignments by making the vertical axis "illiberality." To the extent that society makes benefits less liberal by requiring claimants to comply with costly eligibility conditions, it could be seen as raising the price of those benefits much as suppliers do in other markets. Super, Offering an Invisible Hand, supra note 121, at 828-35. But since illiberality, unlike price, has no logical lower bound-a benefit may be made as generous 
Figure 1:

\section{Supply and Demand for Public Benefits}

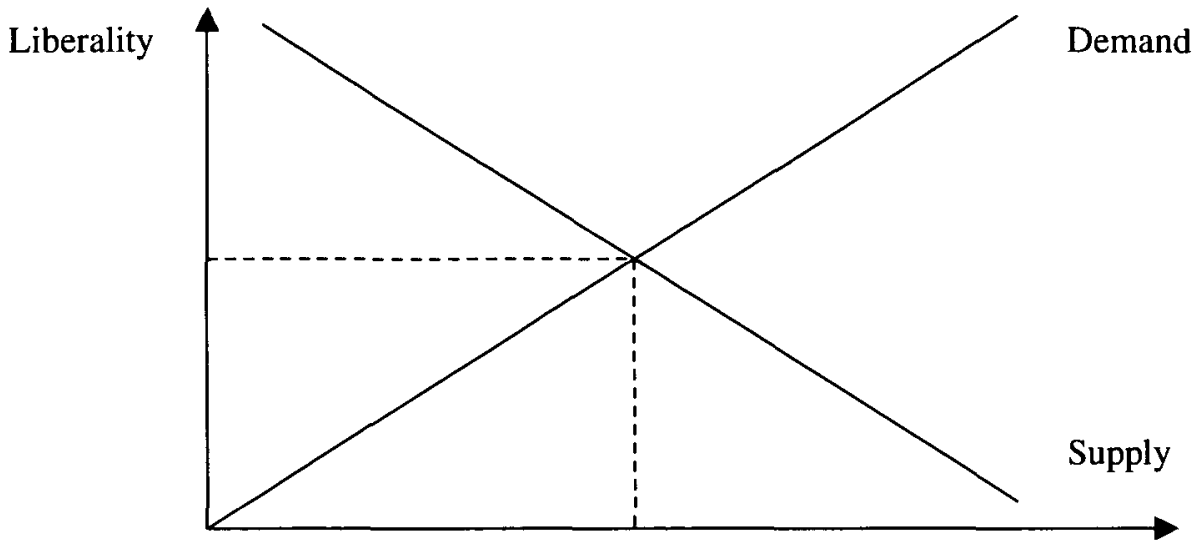

Participation

in which participation is determined by the intersection of these two curves. The "market" for a given benefit clears when the terms of that benefit are made just liberal enough that the number of people claiming the benefit equals the number whom society is willing to serve. ${ }^{127}$

Figure 2 shows the impact of program rules that are not set at the equilibrium level $\left(\mathrm{L}^{*}\right)$ but rather on some more liberal terms $\left(\mathrm{L}^{* *}\right)$. The number of people seeking to participate in the program will move from the equilibrium point $\left(\mathrm{P}^{*}\right)$ to some higher level $\left(\mathrm{P}_{\mathrm{D}}\right)$. The number of people society is willing to serve in this more liberal program, however, will decline because the benefit seems more generous or less conditional $\left(\mathrm{P}_{\mathrm{S}}\right)$. The difference between the number of people seeking to partici-

as society chooses-inverting that axis seems unhelpful. Alternately, the diagram could be recast as presenting the "supply of eligible claimants" and the "demand for giving." These concepts are sufficiently counter-intuitive that the unusual alignment of the curves in the actual diagrams seem less confusing.

127. Arguably a more complete representation of these choices would involve three dimensions. On the X-axis would be the quantity of recipients of the benefit. On the Yaxis would be the size (or adequacy) of the benefit. On the Z-axis is the liberality (or conditionality) of eligibility for the benefit. The supply function would be represented by a curved surface approaching each axis some distance out from its origin. The demand function would be another surface with one corner near the origin. Their intersection would be a line, representing several possible equilibrium points that differ from one another in that they provide different combinations of liberality of eligibility conditions and generosity of benefits. The selection among these equilibrium points, which likely would provide for differing levels of participation, would depend on political and administrative choices in the design of the program. Given, however, the difficulty of thinking-and drawing-in three dimensions, this model is presented in more conventional two-dimensional form, with liberality of eligibility and generosity of benefits aggregated into a single index of liberality. These two quite different factors are then disaggregated below. See infra Part II.A.2. 
FIGURE 2:

EfFect of Overly Liberal Benefit Rules

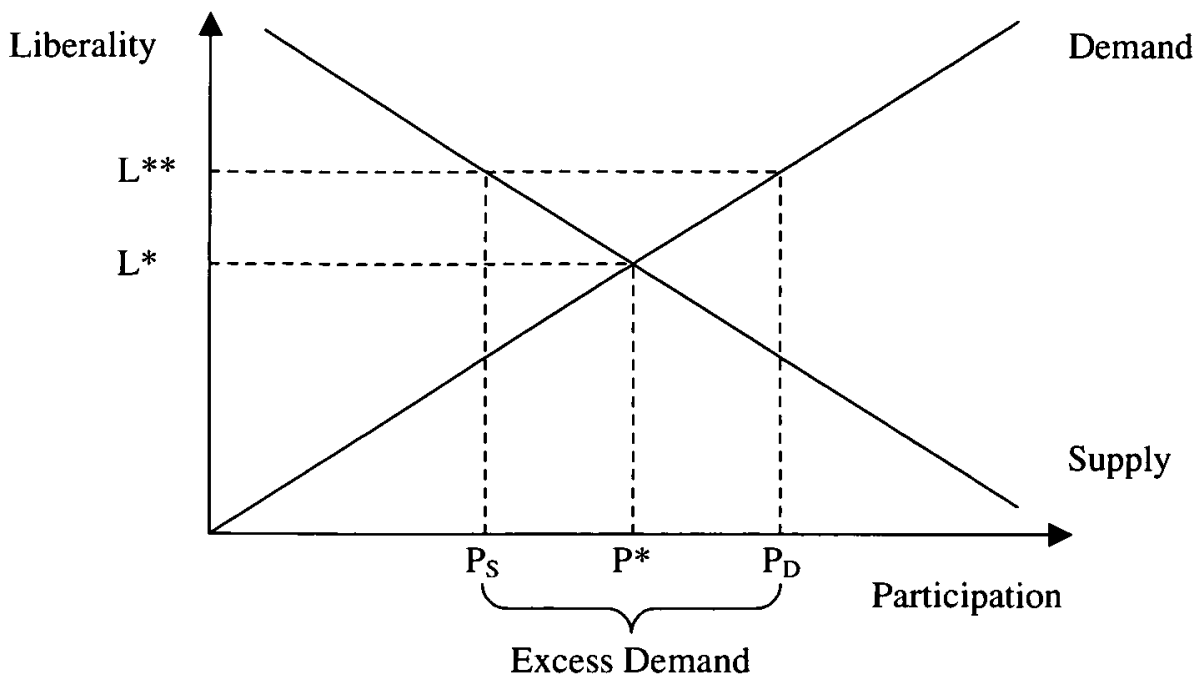

pate and the number society is willing to serve constitutes excess demand. If the program remains a responsive entitlement-if the full numher of people seeking benefits receives them-political pressure will mount to cut back the program.

FIGURE 3:

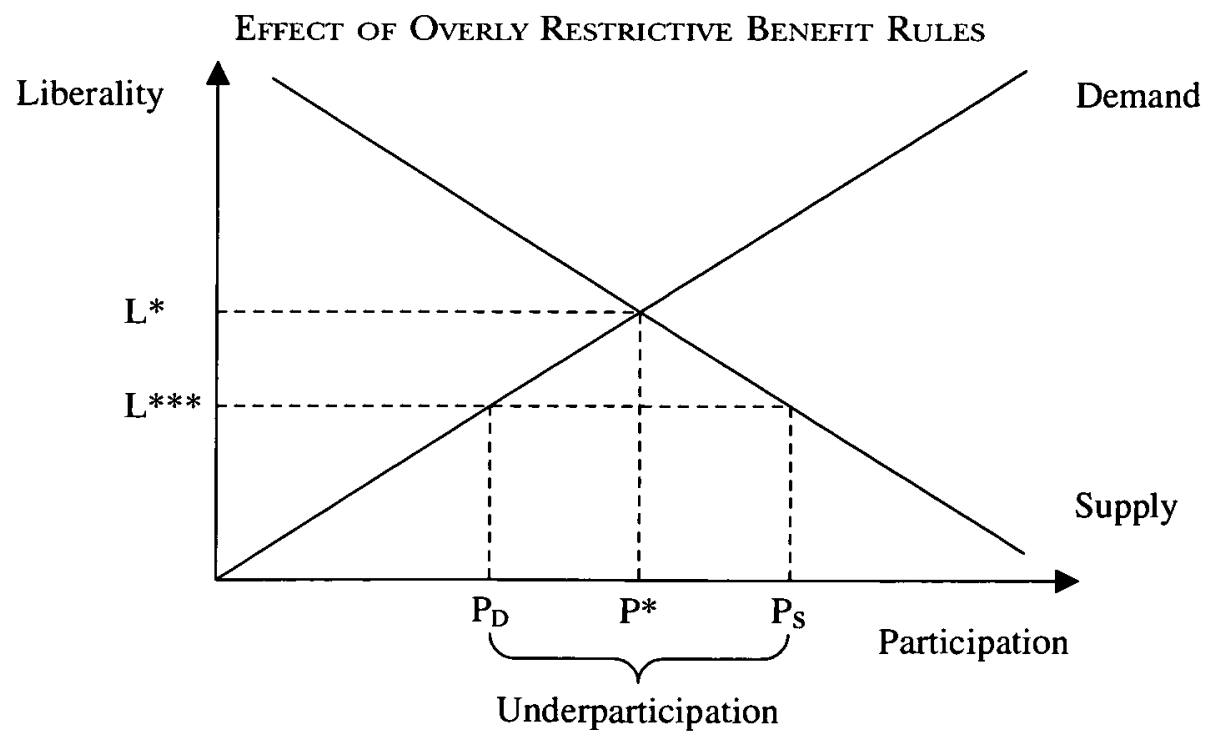

Figure 3 shows the opposite situation: eligibility rules $\left(\mathrm{L}^{* * *}\right)$ more restrictive than the equilibrium level $\left(\mathrm{L}^{*}\right)$. Under these rigorous condi- 
tions, the number of people the public is willing to aid $\left(\mathrm{P}_{\mathrm{S}}\right)$ will exceed the number of eligible claimants interested in the benefit $\left(P_{D}\right)$. The difference is underparticipation. In the near term, it may lead to outreach campaigns. Eventually, advocates for the benefit are likely to succeed in making its benefits more generous or less conditional so that its liberality approaches equilibrium. The path to equilibrium may not be a direct one. If the program's liberality is raised to the equilibrium level, participation is likely to rise slowly at first as word of expanded eligibility or improved benefits spreads. In the interim, the continued low participation may spur another set of liberalizations, resulting in a program whose liberality exceeds the stable equilibrium level. When actual participation catches up with these overly liberal rules, political pressure will build in favor of tightening up the rules. This could well lead to excessive cuts and another period of underparticipation. ${ }^{128}$

Should society become more generous, the supply curve will shift to the right. Society will be willing to serve more people at any given level of liberality. Assuming the demand curve does not move, the shift in the supply curve will result in a shift in the equilibrium point to the left, with society liberalizing the terms of the benefit and thus inducing more people to claim it (either because they have become newly eligible or because the benefit level has become more attractive). Conversely, tighter budgets or impatience with means-tested public benefits may result in society's shifting the supply curve to the left. (Figure 4.) To bring the program back into equilibrium, eligibility conditions will have to be tightened or benefit levels cut so that the overall level of liberality shrinks (from $L_{1}$ to $\mathrm{L}_{2}$ ) and participation drops (from $\mathrm{P}_{1}$ to $\mathrm{P}_{2}$ ).

The demand curve, too, can shift. A recession can cause a shift to the right, causing more people to participate at any given level of generosity in program rules. Economic expansions, an intensification of stigma, or alternative sources of support can cause the demand curve to shift to the left and reduce participation without any change in program rules.

Some events can cause simultaneous shifts in the supply and demand curves. For example, widely recognized economic downturns can both increase demand for means-tested benefits and increase society's willing-

128. Moves to tighten program rules are likely to have much more immediate results. Agencies can quickly terminate recipients that have become ineligible; word of expansions of eligibility will take time to reach potential claimants, who in turn may take some time to apply. Similarly, reductions in benefit level generally can be implemented immediately and may cause the rapid departures of recipients that no longer find the benefits worth the bother of receiving. Increases in benefit levels affect current beneficiaries immediately but may take some time to attract new participants who would not have bothered to apply at the lower benefit level. The impact of both increases and reductions in benefit levels may be slowed somewhat where, as is commonly the case, a program has more formidable barriers to entry than it does to continued receipt. Current recipients will stay on after benefits are reduced below the level that would have caused them to apply initially, but new entrants may continue to come slowly even after benefits have risen. 
Figure 4:

Shift in Supply Curve as Society Becomes Less Generous

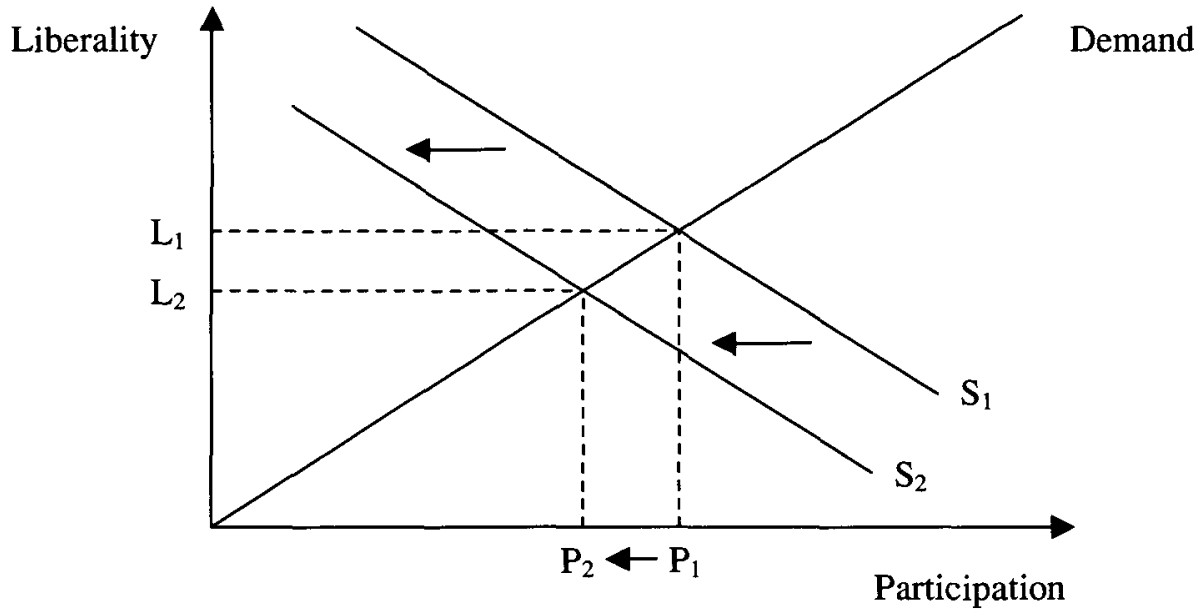

ness to provide them. (Figure 5.) Thus, both the supply and demand curves shift to the right at about the same time. ${ }^{129}$ This allows participation to rise without changing eligibility rules or taking the program out of equilibrium. Indeed, sometimes the increased public sympathy for claimants in recessions outstrips the increase in demand for benefits, allowing liberalizations in programs' rules. ${ }^{130}$

On the other hand, economic expansions often both reduce demand for means-tested benefits and create a societal expectation that participation will fall. If the supply and demand curves shift to the left at a relatively similar pace, eligibility rules can be maintained without throwing the program out of equilibrium. If, however, middle-income people believe that the economy has turned around, they may regard continued high participation in means-tested programs as a sign that claimants are unjustifiably idling and may demand cutbacks. The continued high participation in AFDC and food stamps after the formal end of the recession

129. In practice, downturns often begin to affect the lowest-skill, lowest-income members of society well before major economic indicators and most of the middle-income electorate recognizes the onset of a recession. Also, low-skill workers and other low-income people often tend to be among the last to benefit from an economic expansion. For example, food stamp participation began to rise a year and a half before the recession of 1990-1991 and continued to rise for two-and-a-half years after the formal end of the recession. Author's tabulations of Database Monitoring Branch, U.S. Dep't of Agric., Program Information Reports (1980-2004) (data on file with the Columbia Law Review) [hereinafter Tabulated Keydata Reports] (author's compilation and statistical analysis of twenty-five years of USDA Keydata Reports).

130. A frequent example of this phenomenon is the establishment of emergency unemployment compensation (UC) programs during recessions. 
Figure 5:

Society Accepts an Increase in Need Resulting from a Recession Liberality

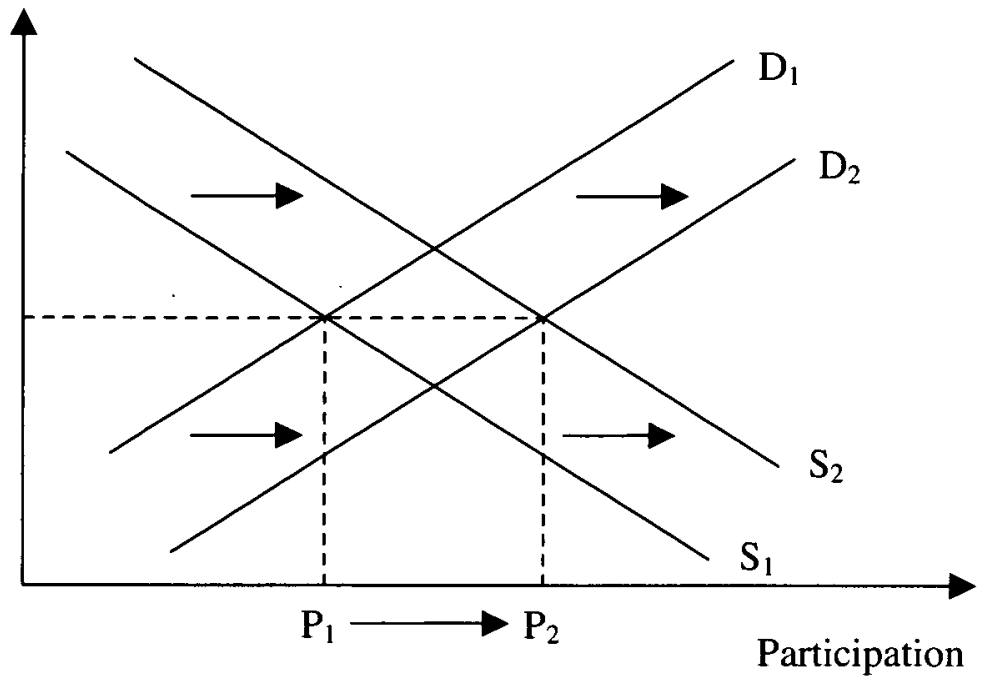

of the early 1990s seems likely to have contributed to public support for the reductions in benefits enacted as part of the 1996 welfare law. ${ }^{131}$

As noted, when, for whatever reason, society becomes less willing to supply benefits or the demand for those benefits increases in ways that society does not embrace, the program must shrink. Figure 6 depicts the two principle alternatives for how that shrinkage may be accomplished. First, eligibility rules can be tightened or benefits reduced, cutting the program's liberality from $L_{1}$ to $L_{2}$ and shrinking participation from $P_{1}$ to $P_{2}$. With these new rules, the program returns to equilibrium. Alternatively, the program can retain its current eligibility rules and benefit structure $\left(L_{1}\right)$ but abandon the responsive entitlement structure. With these still liberal eligibility rules, the number of people seeking benefits remains unchanged at $P_{1}$. Society's willingness to supply benefits at these rules is even lower than it would have been had the rules been tightened. Thus, accommodating the new, more conservative mood will require capping participation at a level $\left(\mathrm{P}_{3}\right)$ well below the equilibrium $\left(\mathrm{P}_{2}\right)$ that could be achieved with stricter program rules.

As Figure 7 shows, an increase in demand for benefits that society does not regard as legitimate creates essentially the same two choices. The program's rules can be toughened (from $\mathrm{L}_{1}$ to $\mathrm{L}_{2}$ ), dampening (though not eliminating) the increase in participation. This allows participation to rise (from $P_{1}$ ) to the program's new equilibrium $\left(P_{2}\right)$. Alternatively, if the program's rules remain unchanged, the number of eligible

131. Personal Responsibility and Work Opportunity Reconciliation Act of 1996 (PRWORA), Pub. L. No. 104-193, 110 Stat. 2105; see supra note 129; see also Newman et al., supra note 37 , at 254, 266 (describing early expectations that growth of the economy and social insurance programs would steadily shrink AFDC roles). 
FIGURE 6:

Two Possible Responses to Society Becoming More Conservative

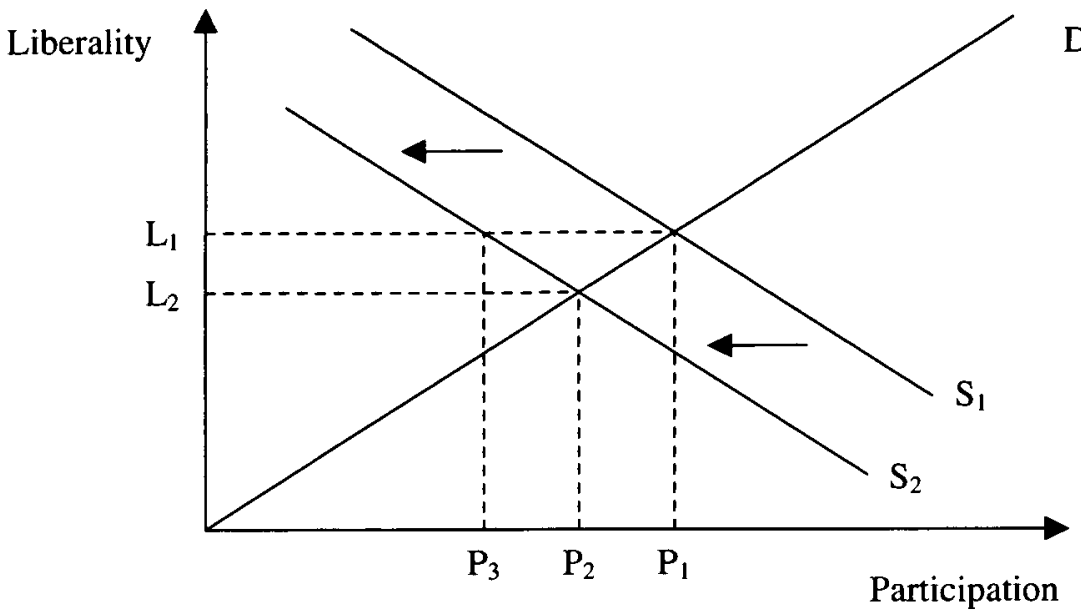

applicants will rise unchecked (to $\mathrm{P}_{3}$ ) while the political system remains unwilling to tolerate any increase above the previous level and imposes a cap. ${ }^{132}$

\section{FIGURE 7:}

Two Possible Responses to an Increase in Need Society Does NOT ACCEPT

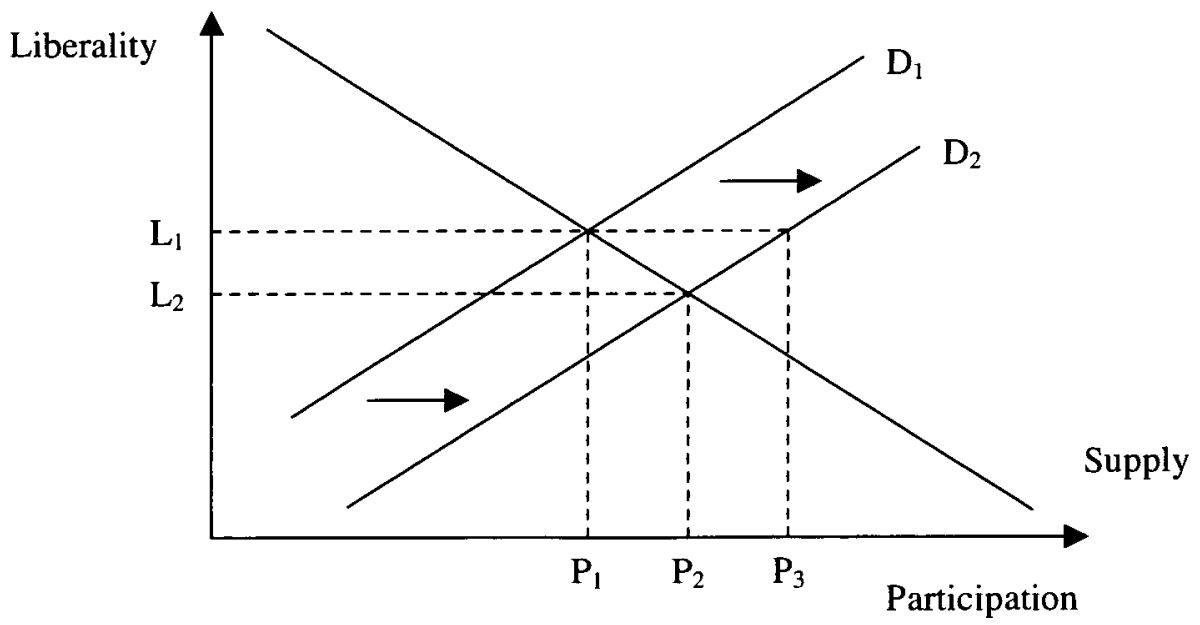

Participation caps-the rejection of responsive entitlement-also can result from political maneuvering. A program's advocates may succeed in increasing the liberality of a program's rules above the equilib-

132. As discussed supra note 91 , many programs are likely to cap funding rather than participation, but the practical effect will be the same either way. 
rium point without building political acceptance for the level of participation such an increase will generate. This may happen when the program's advocates slip a liberalization into broader legislation unnoticed or as part of an "inside" deal. It also may result from misestimates of the impacts of changes in a program's rules. Or it may happen when a program's structure is established without commitments of full funding. Conversely, when conservatives become ascendant they may prefer to cap participation or funding rather than to become embroiled in a debate over specific changes to eligibility rules or benefit levels.

2. Determining the Generosity and Conditionality of Benefits. - The foregoing discussion treats liberality as a single variable. In fact, of course, it is a composite of two quite different sets of variables: benefit level (functionality) and eligibility restrictions (conditionality). Some programs may be quite liberal in one of these respects but restrictive in the other. The school lunch and breakfast programs, for example, have very liberal eligibility rules but quite modest benefits. ${ }^{133}$ Medicaid for nursing home residents or transplant patients, on the other hand, provides extremely costly benefits ${ }^{134}$ but only under very demanding eligibility rules. ${ }^{135}$

133. In the 2003-2004 school year, federal reimbursements to schools for lunches they served ranged from $\$ 0.21$ for children from families with incomes over $185 \%$ of the poverty line to $\$ 2.36$ for children from families below $130 \%$ of the poverty line. National School Lunch, Special Milk, and School Breakfast Programs; National Average Payments/ Maximum Reimbursement Rates, 68 Fed. Reg. 40,623, 40,625 (July 8, 2003).

134. Payments to nursing homes alone-not including payments for doctors' services, hospitalization, and medication for nursing home residents-cost almost $\$ 32$ billion in fiscal year 1998, almost half again the cost of the entire food stamp program. House Comm. on Ways \& Means, 106th Cong., 2000 Green Book 924, 870 (Comm. Print 2000) [hereinafter 2000 Green Book].

135. See, e.g., 42 U.S.C. $\$ 1396 r(e)(7)$ (2000) (establishing procedures to ensure that Medicaid does not reimburse nursing home care that is not medically necessary); id. $\$ \S 1396 \mathrm{a}(\mathrm{f}), 1396 \mathrm{p}$ (allowing states to impose stringent financial requirements and requiring states to attach the assets of Medicaid beneficiaries receiving nursing home care). But see id. $\$ 1396 \mathrm{r}-5$ (relaxing some asset tests applied to married couples).

A host of practical examples demonstrate these tradeoffs. PRWORA imposed severe new conditions on immigrants' participation in programs providing relatively costly benefits-SSI, food stamps, Medicaid, and TANF-funded benefits, for example-while imposing more modest restrictions or none at all on less generous programs such as school meals and WIC vouchers. Compare 8 U.S.C. $\$ \S 1612(a)(1),(b)(1), 1613(a), 1631(a)$ (2000) (restricting many legal immigrants' eligibility for "[f]ederal means-tested public benefit"), with id. $\$ 1613$ (c)(2) (exempting school meals, WIC, short-term disaster assistance, some in-kind services, and some other limited programs from these restrictions). Federal law has never provided cash assistance, medical coverage, or housing subsidies to non-elderly, able-bodied, childless adults based solely on need, but those individuals qualify for at least some food stamps, presumably a less generous benefit. But see Personal Responsibility and Work Opportunity Reconciliation Act of 1996 (PRWORA) $\S 824,7$ U.S.C. $\$ 2015(\mathrm{o})$ (2000) (restricting many such individuals to three months of food stamps in any three-year period unless they are working at least half time). Conversely, although historically high caseloads in AFDC and food stamps were cited as cause for alarm in the welfare debate of the mid-1990s, receipt of more generous but highly conditional unemployment compensation benefits does not arouse anything like the same kind of ire. 
If our model is to merge these dissimilar factors into a single variable for program liberality, we must understand how the political process tends to compare these different factors. In essence, this requires us to construct indifference curves, representing the tradeoffs the political process recognizes between generosity of benefits and relative unconditionality of eligibility. ${ }^{136}$

As Figure 8 suggests, however, not all political systems will evaluate these trade-offs in the same way. The generosity of benefits is likely to be seen primarily in financial terms: The more one is spending, the more care one is inclined to devote to ensuring that it is being spent appropriately. Eligibility conditions, by contrast, have both financial and normative components. For example, programs deny benefits to claimants with resources exceeding specified levels both because doing so saves money and because many people believe that those with greater resources ought to spend those resources rather than turning to the government for help. Similarly, work conditions both save money by denying aid to those that do not meet them and make the public feel that those receiving benefits are more worthy of aid. ${ }^{137}$

136. Decomposing the liberality variable exposes another shortcoming of our model: Raw participation does not fully capture the extent of a program. Consider a program providing $\$ 100$ to 500 claimants. Assume the jurisdiction providing that benefit is considering whether to impose a particular eligibility condition-a resource limit, a work requirement, or perhaps some other behavioral rule-that would cause 100 recipients to leave the program-or to cut everyone's benefits by $\$ 25$. The eligibility condition will reduce participation $20 \%$, which one surmises is likely to be more than the number of people that will lose interest in the program because of the benefit cut. From a financial point of view, however, the benefit cut is more severe: It would reduce total benefit payments to $\$ 37,500$ (even without considering discouraged claimants), compared with $\$ 40,000$ if the eligibility condition is imposed.

Yet neither of these facts tells us how either the political system or potential claimants will regard the tradeoff. If the eligibility condition involves a matter of little normative interest to the general public-perhaps we were thinking of disqualifying people with life insurance policies or those that failed to appear to watch a video on housekeeping skillsthey may not feel that meeting this condition makes someone worthy of an additional $\$ 25$ in benefits. On the other hand, if the eligibility condition is of great public interest-say a work requirement-the public may think it is far more important than a $\$ 25$ benefit reduction and may remain almost as adamant that the condition be met at the $\$ 75$ benefit level as it was at the $\$ 100$ level. A prospective claimant, in turn, will react to these alternatives based on how each impacts her or him. If watching the video requires a claimant to miss a day from work-or if it seems demeaning-she or he may well prefer the benefit cut. Conversely, if the work requirement asks nothing more than the claimant submit some simple documentation of work she or he is already doing, it may seem preferable to a benefit cut.

In fact, if expressed with perfect precision, our model would have two dependent variables: participation and the value conveyed. Since most policies-eligibility conditions and benefit levels-simultaneously affect each of those variables in the same direction (positively or negatively), albeit to differing degrees, in the interest of simplicity this discussion will treat participation as the sole outcome of public benefit programs' rules.

137. The difference between the impact of benefit levels and eligibility conditions is likely to be less pronounced from the point of view of prospective claimants. To be sure, eligibility conditions will take some people completely out of the market; low maximum 


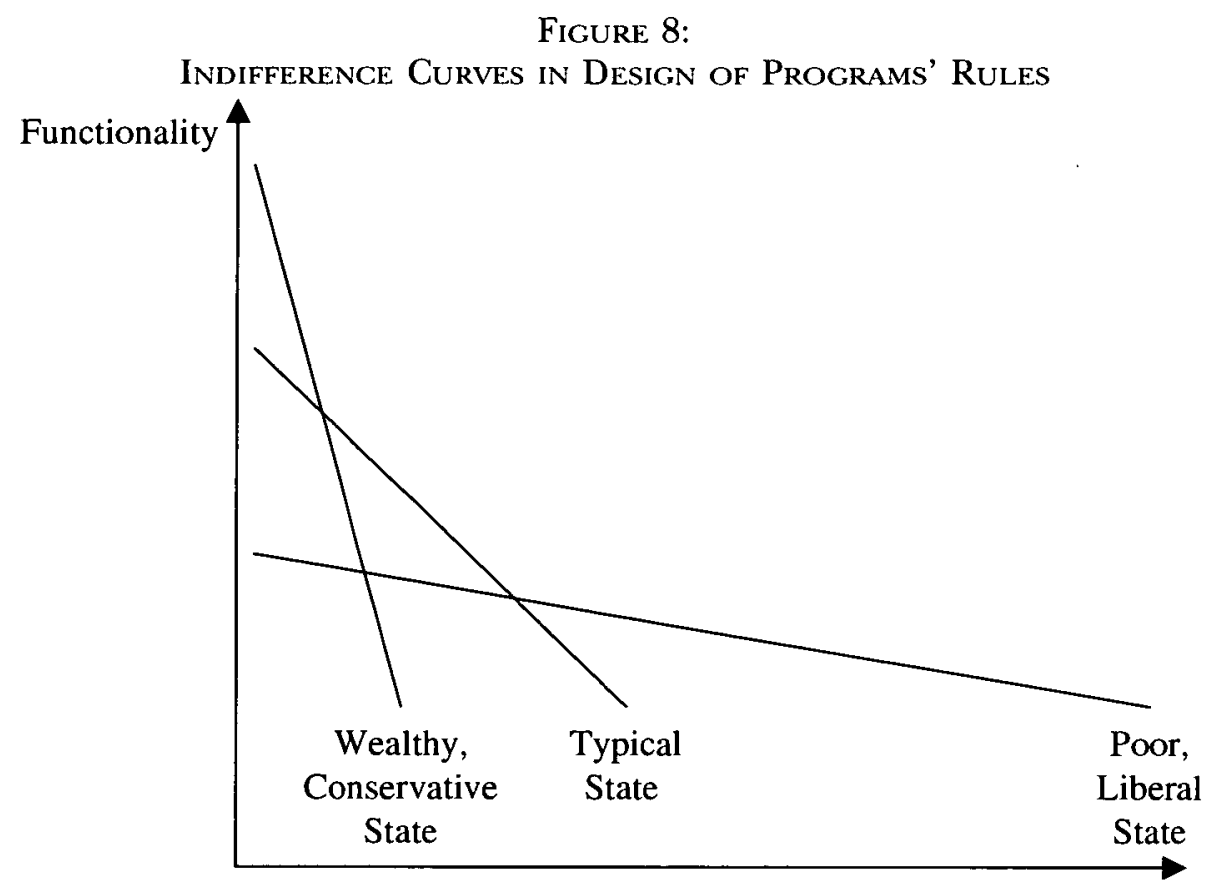

\section{Unconditionality}

Thus, we might imagine that a typical state, with both financial and normative interests in the design of its benefit programs, may give substantial weight to both of these factors. To be sure, a program nearer the upper left end of the indifference curve is likely to cost more than a less conditional one, but we can imagine that the state is willing to bear these additional costs because it is more confident that the people it is helping are those it feels deserve that aid. Some states, however, may have much tighter budgets. Such a state may be able to afford increasing benefit levels relatively little even when it imposes stringent eligibility rules. In other words, benefit levels in this state will be relatively inelastic. If this state has a relatively liberal attitude towards means-tested programs-perhaps because so many voters are themselves in perilous economic posi-

benefit levels do this only if the program phases out the amount of benefits based on income. (Thus, for example, if a program provides $\$ \mathrm{X}$ to someone with no income and then reduces benefits by an amount equal to $20 \%$ of a claimant's income, reducing the maximum benefit amount, $\$ \mathrm{X}$, will reduce the income level at which the benefit has phased out to nothing.) Both benefit levels and eligibility conditions, however, affect the desirability of receiving a benefit. Low benefit levels discourage participation in obvious ways; eligibility conditions make those that remain eligible less likely to receive a benefit because of misunderstandings about eligibility, administrative errors determining eligibility, and the cost of establishing compliance (producing verification and complying with conduct requirements). Thus, it seems less problematic to treat demand for benefits as a function of the liberality of a program's rules, as measured by a rough composite of benefit levels and eligibility conditions. 
tions-it may tend to operate only moderately conditional programs but at fairly meager benefit levels.

Other states may have plenty of funds but view these programs in intensely moral terms. Former Wisconsin Governor Tommy Thompson consistently portrayed his state in these terms. ${ }^{138}$ Wisconsin is generally unwilling to reduce the conditions of participation in its cash assistance program even with substantially reduced benefit levels. ${ }^{139}$ Thus, in Wisconsin benefit levels are relatively elastic with respect to the conditionality of eligibility: Normative factors govern program rules far more than financial considerations.

A financial crisis in a state may both shift the supply curve to the left and rotate its indifference curve counterclockwise, making money a more central determinant of benefits policy. Media stories suggesting that a benefit is being abused also may shift the supply curve to the left but will tend to rotate the indifference curve clockwise, towards placing a higher premium on conditionality. Conversely, economic expansions or improved political fortunes for the program's supporters can both shift the supply curve to the right and change the shape of the state's indifference curve between benefit levels and stringency of eligibility conditions.

Where a state settles on its indifference curve will depend on several political factors. In a state where conditionality is relatively inelastic, claimants' advocates may work to increase benefit levels as much as possible, even at the expense of getting a slightly more conditional program: They may regard this as a good deal for claimants. Similarly, in political systems where program funding is relatively fixed, claimants' advocates may focus their efforts on reducing the conditionality of benefits to keep claimants' cost of qualifying to a minimum (and perhaps to reduce the share of program funds going to administration as opposed to benefits). In almost any jurisdiction, program administrators are likely to seek to move policy towards unconditionality because benefit reductions tend to be easier to administer than eligibility conditions. Service providers, on

138. See, e.g., Jack Tweedie, From D.C. to Des Moines-The Progress of Welfare Reform, State Legislatures, Apr. 2001, at 22, 22 ("I have always said-as loudly and publicly as 1 can-that for welfare reform to be successful you have to make an investment up front. It can't be done on the cheap") (quoting Governor Thompson). But see Frances Fox Piven, Thompson's Easy Ride, The Nation, Feb. 26, 2001, at 4, 4-5 (arguing that Governor Thompson's actions failed to match his rhetoric).

139. Thus, for example, while some other states are willing to excuse families from TANF work requirements at least for some time if they accept sharply reduced benefit levels in the form of a sanction eliminating the parent's share of a grant, State Policy Documentation Project, Sanctions for Noncompliance with Work Requirements, available at http://www.spdp.org/tanf/sanctions/sanctions_findings.htm (last visited Jan. 29, 2004) (on file with the Columbia Law Review), Wisconsin demands work before it will provide any cash assistance to a family. Johannes Bos et al., Manpower Demonstration Research Corp., New Hope for People with Low Incomes: Two-Year Results of a Program to Reduce Poverty and Reform Welfare (Apr. 1999), available at http://www.mdrc.org/publications/ 60/execsum.html (on file with the Columbia Law Review) (citing Wisconsin's work-based system of public assistance, Wisconsin Works, or W-2). 
the other hand, may prefer higher benefit levels even if tighter eligibility conditions mean that those benefits' net value to claimants is reduced. ${ }^{140}$ More generally, the political process tends to be sticky, with changes taking place generally only when the system is delivering results that deviate far enough from current preferences to generate the political attention and drive to force a change. A conditionality-generosity trade-off established at one time in response to the indifference curves then in place is likely to persist for some time even though that curve has taken on a substantially different slope and one or another interest group would gladly move up or down the curve.

\section{B. The Relative Efficiency of Entitlement Structures}

Economists routinely analyze the relative efficiency of various possible ways of organizing private markets. Once the economic nature of entitlement and nonentitlement structures is understood, applying the same kind of analysis to public benefit programs becomes possible. This section begins by considering the circumstances under which responsive and functional entitlements may improve a program's efficiency. ${ }^{141}$ It then considers the circumstances under which it may be desirable to design a program without an entitlement.

1. The Efficiency of Responsive Entitlements. - The two alternatives for resolving mismatches between demand and political supply of benefitschanges in program rules or caps on participation or funding-are more fundamentally different than they might at first appear. A simplistic appraisal of the benefits delivered may not yield any clear preference between the two: Reasonable people may disagree about whether it is better to provide more limited or conditional benefits to a larger number of people or to offer relatively generous and unencumbered benefits to a smaller number. A closer examination of the economics of capped programs, however, exposes serious flaws.

140. If the providers expect that they will have to serve all claimants whether or not they receive a subsidy-as in the case with hospitals concerned about emergency room costs-or have large fixed costs-such as landlords on the low end of a slack housing market-they may prefer to maximize the number of people receiving benefits even if those benefits are relatively meager.

141. This Part does not address unconditional entitlements. As discussed supra Part I.A.2, no program can operate in tbe real world as a true unconditional entitlement. Thus, any discussion of the issue would have to compare the efficiency of having more or fewer conditions on a benefit. Since each additional condition requires some marginal increase in administrative resources, minimizing conditions generally improves efficiency. The difficulty of enforcing possible conditions, however, varies considerably. A detailed analysis of the relative burdens imposed by various kinds of eligibility conditions is well beyond the scope of this article and has been addressed copiously elsewhere. See, e.g., Am. Pub. Human Servs. Ass'n, Crossroads: New Directions in Social Policy 11-24 (2001), available at http://www.aphsa.org/reauthor/crossroads.pdf (on file with the Columbia Law Review); Welfare Simplification \& Coordination Advisory Comm., Time for a Change: Remaking the Nation's Welfare System 49-62 (1993). 
In essence, a capped or nonentitlement program-a discretionary program like housing assistance or a "capped entitlement" such as SCHIP-operates very much like a market that does not clear. ${ }^{142}$ In a market with price controls, demand will exceed supply, the market cannot clear on its own, and some non-market rationing mechanism must be introduced to distribute the limited supply among the overabundant would-be consumers. The most obvious rationing mechanism is to distribute the limited supply of goods on a first-come, first served basis. This will result in goods being allocated to many who value them less than others who, when the seller runs out, receive none. Similarly, too high a minimum wage can be expected to cause the labor supply to exceed the number of available jobs and require non-market mechanisms-queuing, favoritism, side payments, etc.- to allocate the available jobs.

These sorts of non-market allocation systems are commonly criticized on efficiency and other grounds. ${ }^{143}$ The mechanisms by which agencies ration public benefits to stay within a cap are similarly inefficient and likely to frustrate the program's goals as established through the political process. More generally, a responsive entitlement is likely to be easier and cheaper to administer than a capped program. The number of people served is controlled by the terms of the program. Administrators need only judge applicants against the program's eligibility rules and award benefits in the specified amounts to those that meet all applicable conditions. A participation cap inserts an extra step to the administrative process between finding a claimant eligible and calculating her or his benefit level: administering the cap. Moreover, an examination of the specific options available for meeting the demands of a cap shows that each has serious inefficiencies.

a. Waiting Lists and Priority Systems. - An agency can ration benefits with waiting lists. This is the primary mechanism for rationing federal housing subsidies and appears relatively common in capped child care subsidy programs. These lists, however, are likely to deny benefits to people in far greater need than some of those getting benefits.

Frustration with the randomness and irrationality of waiting listsparticularly their failure to recognize sometimes sharp variations in

142. This discussion assumes, of course, that the participation cap is set low enough that it actually constrains participation (presumably as a substitute for stricter eligibility rules). Just as price caps set above the equilibrium price or output controls that exceed demand at equilibrium have little impact on the operation of markets, so too participation caps that are widely recognized as being higher than the likely number of eligible claimants are unlikely to affect programs much. An over-adequate cap that is not recognized as such may inhibit efforts to disseminate information about the availability of the program's benefits and may cause administrators to begin rationing the benefits prematurely. 2003).

143. E.g., Richard A. Posner, Economic Analysis of Law 335-38, 476-81 (6th ed. 
need-can induce agencies to establish priority systems. ${ }^{144}$ Priority systems are likely to require agencies to expend additional administrative efforts to acquire and process more information from claimants. 1mplementing them also may require making arbitrary, often questionable distinctions between very similar claimants. ${ }^{145}$ The targeting of benefits on those most in need may be more appearance than reality. ${ }^{146}$

More fundamentally, the philosophy of priority systems is deeply inconsistent with that of waiting lists. The more people that are pulled out of the queue to receive immediate service, the slower the queue moves for those left to stand in it. This then increases demands to identify other priority categories to be pulled out of the line. ${ }^{147}$ This process is likely to become circular and self-defeating: The more people are pulled from the queue, the longer the wait will be for those that remain and the

144. That is, certain claimants deemed in particularly severe need may be designated for immediate service. For example, homeless families have been given priority for housing subsidies.

145. To be sure, achieving the same savings through increasing the conditionality of a responsive entitlement might well involve making debatable distinctions between similarlysituated claimants. The distinctions required to administer a priority system, however, often will be more arbitrary. An eligibility condition set through the legislative or administrative rulemaking process explicitly disclaims assisting people over a fixed line. The lines drawn in a priority system are likely to be more fluid-since the fraction of claimants that the system must screen out varies depending on demand for the benefit and the program's current budgetary state. Thus, administrators may be forced to differentiate between very similar claimants in order to achieve the required level of savings. Budgetary factors obviously drive the imposition of explicit eligibility conditions, too, but policymakers' longer time horizons may allow them to draw somewhat more rational, coherent lines. Also, administrators adjusting participation with priority systems must rely upon criteria they can quickly adjust if savings prove inadequate; implementation time may not be as severe a limiting factor when setting a permanent eligibility condition.

146. Strong advocates of the privatization of human services, of course, might argue that participation caps create countervailing efficiencies hy forcing claimants from public to private programs. Even if one believes that privatization is more efficient, as opposed to more appealing for other normative reasons, and even if one assumes that private charities actually have the resources to meet this need (i.e., that the claimants turned away from the public program will in fact receive alternative services rather than simply being abandoned), this argument speaks only to the proper size of the public program, not to its method of allocating benefits. Skeptics of public programs presumably would seek to push society's supply curve to the left, allowing it to serve fewer people at any given level of benefit generosity, but they bave no reason to want whatever benefits the government does provide distributed through inefficient rationing mechanisms.

147. Consider a housing subsidy program that gives priority to homeless families. E.g., 24 C.F.R. $\$ \S 882.808$ (a) (3), 960.206(b) (5), 982.207(d)(5) (2003). Media stories about families becoming homeless while enduring long waits for housing subsidies may lead to calls to extend priority to families at risk of homelessness so that they may be saved from the trauma of living on the streets or in shelters and the likely loss of their personal possessions that comes with eviction. Administering such a category requires developing and applying standards for identifying families expected to become homeless before they will receive a subsidy through the regular waiting list. 
greater difficulty they will have enduring until they receive the benefit. ${ }^{148}$ All of this, of course, assumes that the cap is high enough to serve the needs of the subpopulation to whom we are giving priority. If it is not, then the priority category, too, will need a waiting list. ${ }^{149}$ The priority list's failure to deliver benefits, in turn, will spur calls for establishing a super-priority list within the priority group. Further political and bureaucratic resources will be required to define and administer this super-priority list. If enough program resources are siphoned off for super-priority claimants, the "regular" priority list may become as meaningless as the main waiting list.

In the end, we may end up with several tiers of nested programs that seek to approximate a test of claimants' need. Even if we do our job exceedingly well, the cost of administering our priority system will far exceed that of running a simple means test. We also will have carried the program's design far away from that set out in statute; control will have shifted from legislators with at least theoretical political accountability to technicians with virtually none. The complexity of our system will largely preclude thoughtful media scrutiny; at most, a reporter may seize upon one or another anomaly to lambast it as "another example of bureaucracy run amok." In addition, to keep our priority system from crashing, we may develop principles for excluding claimants from one or another priority list that rely upon unrealistic fictions. ${ }^{150}$

Allocating benefits through priority systems also is likely to create a host of perverse behavioral incentives. If families that have had major utilities terminated are deemed at greater risk of homelessness, we effectively reduce the relative benefit of paying these bills. Some families that choose to buy food and allow their gas service to be shut off for this rea-

148. For example, if we start with a queue that requires an average of six months' wait to receive a subsidy and pull out all those families likely to become homeless within six months, the average wait may rise to a year. If we then give priority to those we expect can fend off homelessness for six months but not a full year, the average wait may rise to a year and a half. Eventually, the waiting list may consist only of people who we expect will never become homeless-but they also will never receive subsidies. In essence, we have just converted what purports to be a generally available housing subsidy program into a homelessness prevention program-and done so in a strikingly covert and inefficient way. The program's rules will still nominally grant eligihility to a much broader range of claimants, hut those not adjudged at risk of homelessness under our priority system will have no chance of ever actually receiving benefits. To preserve the illusion that those rules still matter, perhaps we will reserve a few subsidies to be distrihuted without regard to the priority system, as if helping a handful of similarly-situated families somehow henefits the vast number of families mired on a largely futile waiting list.

149. The delays in providing housing subsidies to our priority groups will cause some homeless families to languish in shelters or on the street and will see other families that were at the brink of homelessness tumble over the abyss.

150. For example, we may decide that any family with a close relative living within one hundred miles is per se not at risk of becoming homeless, even if the relative is estranged, lives in a dwelling too small to accommodate the family, or is prohibited by her or his lease from taking the family in. We will then profess amazement when, despite our program for preventing homelessness, families still end up on the street. 
son may become sick from the effects of the cold; others may burn in fires caused by electric or kerosene space heaters. If only families with incomes below a particular arbitrary level are allowed on the priority list, a low-wage worker will have a strong incentive to decline overtime that could put her or him over that line. To be sure, perverse incentives exist in any means-testing system. Priority systems for distributing capped benefits, however, may produce some of the worst incentive packages because they tend to measure more aspects of claimants' lives and because they are more likely to rely upon arbitrary "cliffs" beyond which earning a single additional dollar may effectively bar a claimant from receiving a benefit of considerable value. ${ }^{151}$

b. Covert Eligibility Restrictions. - Even where legislators make a political decision not to operate a responsive entitlement, the difficulties of controlling individual eligibility workers' decisions through any other means are so great that managers may effectively recreate a responsive entitlement as a matter of administrative convenience. ${ }^{152}$ In the absence of a political commitment to a responsive entitlement, managers must regulate spending and participation with repeated adjustments to the generosity and conditionality of the program. Managers compelled to save a fixed amount of money over the remaining months of a fiscal year may feel compelled to take whichever route can be implemented most easily, or whichever one is estimated to produce savings closest to the shortfall they must address, rather than the one that makes the most policy sense. ${ }^{153}$

Agencies can try to reduce participation in a program to the levels the caps allow by restricting the availability of information about that program. This may explain why many programs with capped resources decline to publicize their existence even though doing so could bring them more recognition and funding. This method, too, is likely to deny aid to some of the needier claimants while granting it to more persistent but less destitute ones. ${ }^{154} 1 \mathrm{t}$ also is highly vulnerable to favoritism and tends to privilege people with connections to the public welfare system-not always a group whom the political process would want to reward.

151. See, e.g., 24 C.F.R. $\$ 960.202($ b)(1) (2003) (giving limited priority in public housing admissions to families with incomes below $30 \%$ of the area median).

152. Thus, despite explicit language in PRWORA and a Colorado statute disclaiming any entitlement to cash assistance benefits, program administrators found it necessary to write such specific eligibility rules that the Colorado Court of Appeals found a property interest sufficient to create a positive entitlement enforceable through the Due Process Clause. Weston v. Cassata, 37 P.3d 469, 474-77 (Colo. Ct. App. 2001).

153. Thus, for example, if managers have information on the duration of many claimants' receipt of benefits, they can reliably estimate the savings a time limit would produce. This may make that time limit administratively preferable to requiring their staff to conduct more nuanced examinations of claimants' need for continued aid, a process with less predictable results.

154. See Super, Offering an Invisible Hand, supra note 121, at 827-28 (discussing information-restricting strategy for rationing benefits). 
In a similar vein, agencies can add covert eligibility requirements or simply try to wear out many claimants with procedural denials. Many of the things the program will do to ration benefits among the over-large set of claimants are likely to be inefficient in other ways as well. For example, extensive procedural requirements force claimants to spend much of the value of the benefit gathering and completing paperwork. The net benefit delivered is thus much less than what the government is paying for it. Here again, the distributional effects may be troubling: Low-wage workers, claimants caring for small children or infirm relatives, and others whose time is most valuable are most likely to be discouraged from participating. Moreover, all of these systems are vulnerable to favoritism, covert racial or other discrimination, and side payments, particularly because their complexity renders them largely immune to public oversight. ${ }^{155}$

c. Additional Information Costs and Administrative Burdens. - Whether the agency maintains a waiting list, administers a priority system, or rations benefits in other ways, it almost certainly will require setting up some system for the various eligibility workers and offices taking applications to coordinate their activities on an ongoing basis so that they can avoid exceeding the cap. Gathering and analyzing this information is likely to be quite costly in itself. Even more significantly, responding to indications of over- or underparticipation is likely to require repeated changes in the program's design. These changes must be taught to eligibility workers, programmed into computers, and ultimately explained to claimants, all at no small cost. The frequent, seemingly irrational changes in program rules may breed cynicism among eligibility workers, who may be tempted to ignore or work around changes they dislike, perceiving no great principle to be at stake. Claimants also may become confused and cynical. More ineligible claimants will waste their and the agency's time with futile applications, and more claimants that are eligible will mistakenly believe that they are not. ${ }^{156}$

d. Common Reasons for Eschewing a Responsive Entitlement. - Operating a program as a responsive entitlement requires reducing the liberality of the program's rules whenever society's supply curve shifts to the left or claimants' demand curve shifts to the right (assuming in each case that the other curve does not match this shift). In some circumstances, making these changes can be quite problematic. First, if the number of eligible claimants for a benefit exceeds the number the political system is willing to supply under current rules by $\mathrm{X}$, the tendency will be to tighten the rules enough to drive down participation by $X$. But once the rules are tightened, society is likely to be willing to serve more people than it was in the more generous program (except in the unlikely event that supply is completely inelastic to changes in program liberality). Thus, the changes in eligibility rules that are likely to reduce participation by $\mathrm{X}$ will overcut

155. See infra Part III.B.1.

156. See Super, Offering an Invisible Hand, supra note 121, at 830 . 
and leave a condition of underparticipation. This common error may help explain why many programs go through cycles of cuts and expansions that cannot be fully explained by economic or macro-political changes.

Second, federalism can complicate the process of making cuts. 1n AFDC, for example, the federal government had very limited options to reduce the generosity of benefit levels, which were largely set by states. ${ }^{157}$ If the political coalition controlling the federal government has little control over benefit levels and lacks sufficient politically acceptable means of tightening a program's eligibility, capping participation-or at least federal contributions-may appear to be the most desirable option. This appears to have been a factor in Congress's imposition of an AFDC participation cap in the $1960 \mathrm{~s}^{158}$ and again in the block granting of AFDC in 1996. The TANF block grant capped federal contributions ${ }^{159}$ and gave states the choice of imposing participation caps or making the program's rules less liberal through means that were unavailable to federal policymakers under AFDC's structure. AFDC might well have been eliminated anyway, but the paucity of policy levers at the federal government to tighten the program's rules at least prevented its defenders from offering a leaner, more stringent AFDC program as a credible alternative to block granting.

2. The Efficiency of Functional Entitlements. - Up to this point, we have been treating the level of generosity of benefits as essentially arbitrary. 1n other words, we have assumed that the programs at issue were not functional entitlements. Yet operating a program without tying benefit levels to a functional entitlement will often be inefficient as well.

In particular, programs providing benefits insufficient to purchase a plausible quantity of a good or service in existing markets may severely distort those markets. ${ }^{160}$ In this regard, it is important to differentiate

157. But see 42 U.S.C. $\$ 602$ (a) (10)(B) (1994) (repealed 1996) (requiring benefits be pro-rated for month of application). This provision was added in the Omnibus Budget Reconciliation Act of 1981, Pub. L. No. 97-35, 95 Stat. 357, 843-74, to reduce federal spending.

158. Social Security Amendments of 1967, Pub. L. No. 90-248, $\$ 208,81$ Stat. 821, 894 (1968); see H.R. Rep. No. 90-544, at 110 (1967) (declaring that federal funding for AFDC should be kept "within reasonable bounds" and suggesting that states needed incentives to implement federal policies seeking to reduce AFDC participation).

159. 42 U.S.C. $\$ 603(\mathrm{a})(1)(\mathrm{A})$ (2000) (setting formula for determining amount of basic TANF block grants); see id. $\$ 601$ (b) (disavowing any right to assistance on behalf of any claimant); id. $\$ 603(\mathrm{~b})(2)$ (capping amount federal government will provide to supplement these block grants through contingency fund in times of severe need); id. $\$ 606(\mathrm{e})$ (similarly capping amount federal government would loan states in times of severe need).

160. The converse also is theoretically true: A program that provides benefits sufficient to purchase more of a commodity than its recipients wish to consume could distort markets in different ways. Whether recipients accept the constraint or sell their unwanted benefits at a discount, value is likely to be lost. These concerns are central to arguments for cashing out in-kind benefits. See, e.g., Martha B. Coven, The Freedom to 
between benefits that recipients can readily supplement and those that they cannot. The Low-Income Home Energy Assistance Program (LIHEAP), ${ }^{161}$ for example, does not provide a functional entitlement to utility service. LIHEAP recipients, however, are free to supplement government aid with their own payments to utility companies. ${ }^{162}$

Medicaid, on the other hand, prohibits providers from accepting payments from beneficiaries or their responsible relatives. ${ }^{163}$ When Medicaid sets its fee schedule below market levels, ${ }^{164}$ therefore, that limits what providers may receive for their services. Figure 9 illustrates the difficulties this can cause. If the state set its fee for a particular Medicaid service at the level $\left(\mathrm{P}^{*}\right)$ that would attract enough providers to serve the number of beneficiaries it can afford to cover at that price $\left(Q^{*}\right)$, the market will clear. ${ }^{165}$ If, however, the state seeks to save money by capping reimbursements at a lower level $\left(\mathrm{P}^{* *}\right)$, it will be able to afford to cover more beneficiaries $\left(Q_{D}\right)$. Many of the better providers, however, will drop away, leaving the available supply of medical care at a level ( $Q_{s}$ ) below that needed by these beneficiaries. This imbalance may be resolved in several inefficient and undesirable ways: illegal side payments to providers, ${ }^{166}$ queuing for medical care that sbould not be postponed, tolerance by licensing officials of incompetent providers, etc.

An intermediate case may be a program that technically allows recipients to supplement its payments but that pays for a service that, in practice, is so expensive that many cannot afford to do so. Some housing and

Spend: The Case for Cash-Based Public Assistance, 86 Minn. L. Rev. 847, 849-51 (2002) (arguing that, apart from political considerations, means-tested benefits should be provided in cash). In practice, however, public programs rarely provide hyperadequate benefits: If they did, they would have difficulty fending off attempts to harvest their surplus funds for purposes generating higher rents. And constraining benefits' use can improve the political legitimacy of a program as well as the accuracy of its targeting. Super, Offering an Invisible Hand, supra note 121, at 829.

16I. 42 U.S.C. $\$ 8621$.

162. Id.

I63. Id. § 1396a(a) (25) (C).

164. See, e.g., Clark v. Kizer, 758 F. Supp. 572, 577 (E.D. Cal. 1990) (finding tbat California's Medicaid reimbursement rates for dentists were lower than the customary rates of more than ninety-nine percent of the state's dentists), vacated in part sub nom. Clark v. Coye, No. 92-15131, 1992 U.S. App. LEXIS I5044, at*2, *8-*11 (9th Cir 1992) (affirming the substance of the district court's decision but finding its remedial order was no longer needed); Morgan v. Cohen, 665 F. Supp. 1164, 1167-68 (E.D. Pa. 1987) (noting that Pennsylvania's Medicaid program reimbursed outpatient psychiatric treatment at $\$ 5.50$ per bour).

165. Here, of course, we are back to discussing a conventional private sector market for a service-medical care-and our supply and demand curves are in their familiar positions.

166. See, e.g., Cliff House Nursing Home v. Dep't of Pub. Health, 463 N.E.2d 578, 580 (Mass. App. Ct. 1984) (disqualifying nursing home from favorable rate treatment where nursing home administrator accepted payments from Medicaid beneficiaries' families); Glengariff Corp. v. Snook, 471 N.Y.S.2d 973, 976, 978 (Sup. Ct. 1984) (bolding solicitation of additional payments from medical beneficiaries' friends and family contrary to statutes and public policy). 
Figure 9:

Effect of Public Benefit That is Not a Functional Entitlement Price

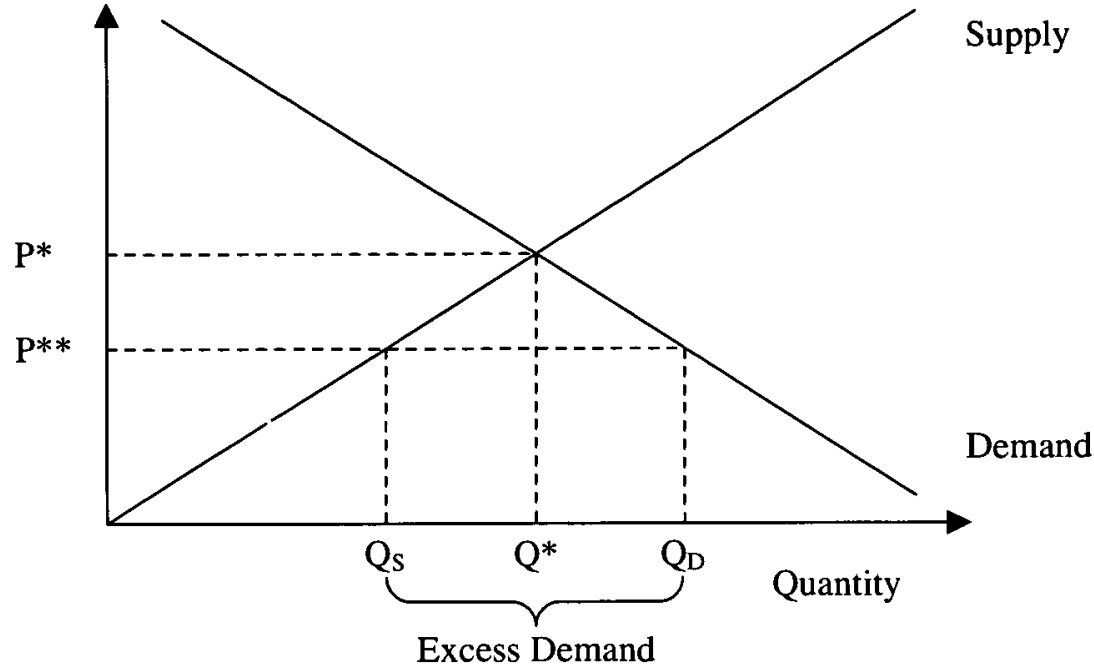

child care subsidies fall in this category; health care coverage under some state-operated programs may also allow beneficiaries to supplement its payments. For those who can afford to supplement-generally the least poor recipients-these programs provide useful partial payments in the manner of LIHEAP. For those who cannot, an inefficient process is likely to ensue in which a large number of recipients chase a smaller number of providers willing to serve them at the set price. If the program imposes quality standards (as child care and federal housing subsidy programs typically do), the benefit may actually become useless to the lowest-income recipients if the unsubsidized cost of below-standard services is less than tbe cost of supplementing the government benefit enough to attract providers that meet the program's standards. In any event, the program will be providing what amount to inferior benefits (or none at all) to the poorest recipients even while nominally treating all claimants alike. ${ }^{167}$

3. The Particular Inefficiency of Block Grants. - Block grants that are not responsive entitlements ${ }^{168}$ are vulnerable to all the inefficiencies of other capped programs and face some additional shortcomings all their own. ${ }^{169}$ In addition to difficulties allocating available resources among

167. This raises serious questions of political transparency, which are addressed infra Part 11I.B.

168. See supra text accompanying note 92 .

169. See generally, e.g., Food Stamps, supra note 12, at 13 ("A block grant would force states with declining economies, rapidly growing populations, or poverty levels that are rising for other reasons, to choose between cutting benefits substantially or providing large amounts of state funds to meet the increasing need."); Jon Michaels, Deforming Welfare, 34 Seton Hall L. Rev. 573, 598-99 (2004) (arguing that devolution to states is 
claimants, federal block grant programs also must divide funds among states, and state block grants must divide funds among localities.

Even in an apolitical world of perfect information, finding the optimal formula would be difficult. Should it be based exclusively on need? If so, should funds be allocated based on the total number of potentially eligible claimants or the number likely to be served? Should funding level take into account the cost of the benefits to be provided as well as the number of claimants? ${ }^{170}$ Block grants also often give recipient governments considerable discretion in setting eligibility levels; this raises the question of whether the funding formula should consider only those claimants the recipient government actually makes eligible or all those it could choose to cover. Alternatively, many will argue that funding also should reflect the recipient government's performance in some regard. Finding a reliable, unbiased formula for measuring the government's achievement of its many complex and often-conflicting objectives is extremely difficult. If meaningful performance measures can be found, however, and if they become important parts of the funding formula, they may systematically deprive weak performers of the resources they need to improve.

Information in our world, however, is anything but perfect. Broad demographic information generally is insufficient to determine exactly which individuals or families are in fact eligible for aid under any particular set of rules. Difficult questions then arise about which approximation of eligibility ought to be used (e.g., the number of people below a given income threshold or the number unemployed). Information also takes time to gather and more time to translate into funding decisions. The number of people living in poverty in 2003 will not be known until the very end of federal fiscal year 2004 and hence could not be translated into funding levels until 2005 at the earliest. ${ }^{171}$ State-level estimates of the number of people in poverty are subject to significant sampling error, especially in small states. ${ }^{172}$ But if that error is offset by pooling three years' data, the temporal match between need and funding will be even

inconsistent with both the new behavioralist goals of welfare policy as well as the residual interest in protecting low-income families from severe harm).

170. For example, if two states have the same number of families living below a given income eligibility limit, should it matter that one of them has twice as many people living below half of that limit, and thus perhaps in need of more extensive benefits? In a health program, should a state whose eligible population is older or sicker get more funding? In a housing program, should the higher market rents in Northeastern and West Coast states be taken into account?

17I. Given that recipient governments need some lead time to plan how to design their programs, an even greater delay may be required to avoid wasteful, unplanned spending in states getting increased allotments, and chaotic cuts in states losing funds.

172. Even less data is available to measure need in particular counties or cities for distribution of state block grant funds. The inefficiencies resulting from malallocation of resources in programs that states block-grant to localities therefore are likely to be even more severe. 
further removed. Areas with growing populations will be shortchanged, as will areas whose economies have declined in the intervening period.

Our world also is not apolitical. The questions about funding formulas are sufficiently debatable and sufficiently technical that legislators can freely advocate for whichever one best serves their constituencies. Sometimes this results in coalitions arising or powerful committee chairs skewing formulas in their favor; on other occasions, the compromise often is to rely primarily on prior years' funding: the baseline. ${ }^{173}$ The longer a block grant program operates on such a formula, the more disparities will develop between states-the more money will be allocated to states where it can accomplish less than it could in other states.

By shifting program design and operations down to smaller units of government, some significant economies of scale are likely to be lost. Most states can afford fewer and less expert program designers than can federal agencies; program design on the local level is likely to be extremely primitive except in the largest of cities. The result of this less sophisticated design is likely to be more perverse incentives in programs' eligibility and benefit structures. ${ }^{174}$ Also, more simply, it requires fifty state policy-writers, training designers, etc., to replicate essentially the same program design functions. Moreover, some aspects of program operations have significant economies of scale. Prior to the food stamp program's conversion to electronic benefits, ${ }^{175}$ USDA was able to print far more counterfeit-resistant food stamps than individual states could have. The federal government's resources allow for more sophisticated computerized fraud detection efforts than any state likely could mount on its own. ${ }^{176}$

4. Types of Programs Rationally Run as Nonentitlements. - Despite the significant advantages of responsive and functional entitlements, some programs are quite appropriately operated as neither. Political and budgetary constraints often make it impossible to enact a program that simultaneously is a responsive entitlement and serves a coherent, meaningful function. Many important and successful benefit programs, in-

173. See infra Part III.

174. To be sure, state and local policy analysts have no patent on program designs creating perverse incentives: AFDC was a federal creation. Indeed, states have improved on the gnarled program designs federal politics sometimes produce. For example, the vast majority of the waivers states obtained from AFDC's rules reduced its disincentives to work by increasing the amount of earnings disregarded in computing AFDC eligibility and benefit levels. R. Kent Weaver, Ending Welfare as We Know It 259 (2000). AFDC counted seventy percent of earnings that exceeded $\$ 120$ as income to reduce families' benefits; even these limited exemptions shrank after a few months. 42 U.S.C. $\S 602$ (a) (8) (1994) (repealed 1996). Many states' waivers disregarded the first $\$ 200$ that a family earned each month as well as half of all earnings above that threshold and allowed these disregards to continue as long as the family received benefits.

175. See 7 U.S.C. $\$ 2016(1)(1)(A)$ (2000) (requiring all states to implement electronic benefit transfer systems for food stamps by October 1, 2002, subject to very limited exceptions).

176. See Food Stamps, supra note 12, at 10 (describing those systems). 
cluding food stamps, WIC, SCHIP, and LIHEAP, began as demonstration projects of one kind or another. In these cases, a choice between a responsive entitlement and a functional entitlement may be necessary.

a. Instrumental Programs. - The goals of a program often will determine which design is most sensible. If it seeks primarily to benefit its recipients, a responsive entitlement is crucial to avoiding the kinds of inefficiencies described above. This is true even if the program must be heavily conditioned (for example, by limiting beneficiaries to a narrow age bracket or to residents of a small geographic area).

Where the goals of the program are primarily instrumental, on the other hand, a responsive entitlement may be less important. The key is whether the government is acting as a supplier or a consumer in the market. If it is seeking to supply a public benefit to claimants as consumers, a responsive entitlement makes sense. ${ }^{177}$ If, on the other hand, it is acting as a consumer on its own behalf or that of a broad segment of the public, it can tailor the extent of its spending to the amount that it feels it can afford. A pilot project, for example, may benefit its participants, but its primary purpose is to purchase data. In exploring the effects of a benefit on people in a variety of circumstances, the sponsoring agency may not be able to condition the benefit sufficiently to allow benefits to be provided in a responsive entitlement. Indeed, in this case a functional entitlement may be crucial: If the benefits being tested have been diluted to the point that they fall far short of meeting recipients' definable needs, the evaluation is likely to show no impact. The program will have to bear the burden of administering a rationing system, but it is not seeking to establish a stable market for the benefit. ${ }^{178}$

Similarly, although public employment obviously benefits those hired, its primary purpose presumably is to get work done for the government. Thus, we all take it for granted that the government will not hire all comers but will ration that benefit through a screening and selection process. The care that civil service rules require government agencies to take to protect against favoritism, corruption, or political bias in govern-

177. In the same way, the postal service and public transportation agencies seek to serve their customers by supplying delivery services or carriage. If the postal service capped the amount of stamps it would sell, or a transit service set an arbitrary limit on the number of rides it would provide, each would collapse under the weight of allocating its quota.

178. A host of other public functions are properly conducted on capped budgets because they are not designed primarily to benefit the direct recipients of governmental funds. Purchases of land for national parks and forests, art works for museums, or experiments for the space program primarily seek not to benefit the vendors but to acquire something of value for the government and the general public. Although establishing and implementing selection criteria is costly and potentially vulnerable to error and manipulation, the government has no reason to empty the market. It can define its own needs and declare itself satiated when it has reached its budget constraint. In these activities, the government is participating in an existing market as a consumer rather than creating a new market in a public benefit that it produces. 
ment hiring-and the shortcomings that process nonetheless experiences-provides a useful reminder of the difficulty of rationing government benefits without the market mechanism that responsive entitlements offer.

b. Federalism Concerns. - In recent years, the desire to decentralize has become the leading reason for establishing capped programs or for capping existing responsive entitlements by converting them to block grants. ${ }^{179}$ Block grants' proponents argue that local officials will design superior substantive policies because they know more about local conditions. Unquestionably, a bad enough program design could create worse inefficiencies than the rationing mechanisms required to operate capped programs. An employment and training program that teaches ice fishing in Florida or serving tourist divers on the North Slope of Alaska would be a waste of money no matter how it selected its participants. But not all decisions need to be decentralized, and many important decisions can be decentralized within the context of responsive entitlements.

Decentralization may plausibly justify abandonment of a responsive entitlement under either of two circumstances. First, some decisions are so dependent on local circumstances that they can only be made at the state or (perhaps) local level. Second, some decisions that theoretically could be made well on the federal level will, for one reason or another, be predictably mishandled. In essence, decentralization may be required because of a failure of the political market at the federal level. Arguments that both of these conditions existed figured prominently in the justifications for eliminating responsive entitlements to cash assistance and child care subsidies in PRWORA.

Each of these arguments merits some scrutiny: In many cases, it will prove unnecessary to abandon the benefits of a responsive entitlement. Many responsive entitlements operate in fields where some decisions need to be made locally. For example, the National School Lunch Program establishes functional nutritional standards that meals must meet ${ }^{180}$ but leaves to local schools decisions about what specifically to serve, ${ }^{181}$ in deference to their experience with what their students will actually eat. Similarly, AFDC required employment and training programs but allowed states to determine the content of those programs: ${ }^{182}$ If Florida's E\&T program ever were to teach ice-fishing, it would be no one's fault but Florida's. States controlled standards and reimbursement rates for

179. In addition, decentralization is commonly cited as justification for dismantling federal standards that seek to assure a functional entitlement. Arguably, however, decentralized programs need clear performance standards more than those administered directly by the federal government. By analogy, a shopkeeper is likely to give much looser instructions to her staff if she plans to be present in the store all day than if she expects to be away. Even if she has absolute faith in her staff's desire to "do the right thing," she still needs to let them know what objectives they are trying to meet.

180. 42 U.S.C. $\$ 1758(\mathrm{a})(1)(\mathrm{A})$, (f) (1) (2000).

181. Id. $\S 1758(\mathrm{f})(4)(\mathrm{A})$.

182. 42 U.S.C. $\S 682(\mathrm{a})(1)(B),(d)(1)(B),(e),(f),(g)$ (1994) (repealed 1996). 
child care providers before and after PRWORA. Most of the decisions that PRWORA decentralized involved distribution of benefits-basic means-testing decisions on which state and local governments have no obvious comparative advantage. People want and need money to largely the same extent everywhere and are likely to respond similarly to financial incentives. PRWORA's proponents continuously repeated the mantra that decentralization would allow states to respond better to local conditions ${ }^{183}$ but had little to say about which specific decisions dependent on those conditions had been denied to states under prior law.

In addition, even if we believe that the federal government is experiencing political market failure, ${ }^{184}$ it behooves us to determine the extent and intractability of that failure. We do not take a commodity completely out of commerce simply because high information costs, monopoly, or other distortions afflict its market. In the same way, the inefficiencies of the ad hoc rationing systems that must operate in the absence of a responsive entitlement-and the additional inefficiencies of allocating block grant funds among states-are a high and often unnecessary price to pay for correcting a discrete failure of the federal political system. If, as PRWORA's proponents argued, the federal government was politically incapable of imposing tough work requirements, ${ }^{185}$ giving states the authority to do so within the existing responsive entitlement (and perhaps imposing work participation rates on the states to insure that they did so) would seem a more focused response to the perceived problem. ${ }^{186}$ In either case, where authority is more efficiently decentralized because of the importance of local factors or because of political market failure at the federal level, the advantages of decentralization should be weighed against the inefficiencies of eliminating a responsive entitlement. This weighing might lead policymakers to search more diligently for systems

183. See, e.g., 141 Cong. Rec. 8492 (1995) (statement of House Ways and Means Committee Chairman Archer) (declaring that "the foundation of [the legislation that became PRWORA] is our commitment to shrink the Federal Government by returning power and flexibility to the States and communities where the needy can be helped the most").

184. See infra notes 338-341 and accompanying text.

185. During the political frenzy that engulfed the welfare reform debate of 1995-1996, this remarkable argument was allowed to pass without serious scrutiny. PRWORA's supporters' leading piece of evidence that the federal government was incapable of imposing serious work requirements was the low number of AFDC recipients engaged in employment and training activities as a result of the Family Support Act of 1988, Pub. L. No. 100-485, 102 Stat. 2343. E.g., 141 Cong. Rec. 9100 (1995) (statement of Rep. Talent). Yet this failure resulted primarily from states' failure to draw down the funds the Family Support Act provided for work programs. In any more reflective political environment, it is difficult to imagine how the states' entropy could be charged to the federal government and could justify giving those same states far greater control of federal funds.

186. In fact, once the hlock grant mechanism had been decided upon, conservatives largely abandoned arguments about failures of the federal political market. Indeed, the dominant theme of the 2002-2003 reauthorization of the TANF block grant has been greater federal control of work requirements through tougher work participation rates. 
that decentralize particular decisions while maintaining responsive entitlements.

\section{Responsive and Functional Entitlements' Impact on Programs' Policy Goals}

A fundamental tension in the design of means-tested public benefits programs exists between targeting aid on those most in need and providing incentives for work and other favored behavior. ${ }^{187}$ Given the difficulty of accommodating these two purposes under the best of circumstances, policymakers should take care to avoid programmatic structures that exacerbate the conflict or reduce a program's effectiveness in serving one of these goals without simultaneously improving its results on the other.

1. Incentive Effects. - A traditional economic criticism of meanstested public benefit programs is that they dampen work incentives. ${ }^{188}$ In effect, this criticism asserts that the government, acting as a supplier of income, is unfairly or undesirably competing with other suppliers of income, specifically private employers ${ }^{189}$ (and perhaps prospective spouses $\left.{ }^{190}\right)$. The ascendancy of these arguments has coincided with attacks against entitlement programs. In fact, responsive entitlements often provide clearer incentives than programs with capped participation. A responsive entitlement provides greater certainty about the consequences of taking a particular action than a capped program. A claim-

187. Compare, e.g., David T. Ellwood, Poor Support 24-25 (1988) (corresponding to the "moral judgment" model of program operations and describing the "conundrum" that "when we target people [in need], we often label them, change the rules, lower their incentives, and break down the political links that help maintain public support for aid"), with, e.g., Jerry L. Mashaw, Bureaucratic Justice 21-23 (1983) (corresponding to the "professional treatment" vision of program operations).

188. See, e.g., Kathryn Edin \& Laura Lein, Making Ends Meet 218 (1997) ("The federal welfare rules present welfare-reliant mothers with a stark choice: follow the ruleswhich disallow supplemental income-and subject their families to severe hardship, or break the rules. Virtually all welfare-reliant mothers with whom we spoke . . chose their family's welfare."); Ellwood, supra note 187, at 19-20 (arguing that there is no serious dispute that " $[w]$ hen you give people money, food, or housing, you reduce the pressure on them to work and care for themselves"); Posner, supra note 143, at 479-80 (discussing various means of addressing the "incentive problem" inherent in cash transfers); Michael Tanner et al., Cato Inst., Policy Analysis No. 240, The Work Versus Welfare Trade-off: An Analysis of the Total Level of Welfare Benefits by State (Sept. 19, 1995), available at http:// www.cato.org/pubs/pas/pa-240.html (on file with the Columbia Law Review) ("The choice of welfare over work is often a rational decision based on the economic incentives presented.").

189. Ellwood, supra note 187 , at 137-41 (describing how the perverse incentives of the welfare program leave many recipients with no viable income-producing alternative other than to remain on welfare).

190. See, e.g., Patrick F. Fagan et al., Heritage Found., Backgrounder No. 1606, Marriage and Welfare Reform: The Overwhelming Evidence that Marriage Education Works 3 (Oct. 25, 2002), available at http://www.heritage.org/research/welfare/ bgl606.cfm (on file with the Columbia Law Review) (arguing that "the welfare system has punished marriage and rewarded single parenthood for a generation"). 
ant may misjudge the incentives that a capped program offers, either over- or under-estimating the chances that he or she may qualify (and hence be affected by the program's incentives). Claimants that respond to what they believe are a program's incentives only to be denied benefits due to a cap are likely to become cynical and less sensitive to incentives in the future. ${ }^{191}$

More importantly, a responsive entitlement differs from a capped program with a similar budget in that it distributes a reduced or more conditional benefit to all claimants rather than applying more generous rules to a fortunate subset of those eligible. If the program achieves equilibrium by reducing the benefit package, it will have a smaller amount to phase out and can do so more gradually. ${ }^{192}$ If, on the other hand, the responsive entitlement reaches equilibrium by making the benefit more conditional, the conditions selected can seek to provide positive incentives. ${ }^{193}$

Responsive entitlements also reinforce the importance of behavior eligibility conditions. Consider a program whose eligibility conditions include a work requirement. If that program is a responsive entitlement, the value of complying with that work requirement equals the value of the benefit the program provides. If, however, the program caps participation at a level equal to half of aggregate demand, complying with the work requirement only brings a fifty percent chance of a reward; assuming that a claimant is risk neutral, she will discount the value of complying by half. More likely, since complying has direct and opportunity costs to the claimant, she may be somewhat risk-averse towards the program. The message that work requirement sends also may be muddled. From the claimant's point of view, it may appear that techniques for manipulating the program's priority system are at least as important as complying with the program's requirements. Indeed, if administrators' struggles to

191. Late in the debate on PRWORA, Sen. Moseley-Braun made this point, arguing that repealing the responsive entitlement to cash assistance undermined the bill's work conditions: "This legislation does not give able-bodied people a chance to work and support their own children." 142 Cong. Rec. 18,485 (1996).

192. For example, phasing out a $\$ 1,000$ benefit in such a way that claimants become ineligible when their earnings reach $\$ 10,000$ allows benefit reductions that offset only ten percent of the rewards from increased work effort. By contrast, a $\$ 2,000$ benefit being phased out over the same income range would require twenty percent of the value of each increase in claimants' wages to be siphoned off. For a general discussion of the problem of phasing down benefits, see Edgar K. Browning \& Jacquelene M. Browning, Public Finance and the Price System 281-85 (3d ed. 1987); Cong. Budget Office, 1mplicit Marginal Tax Rates: Comparing the Health Security Act and the Managed Competition Act with Current Law 7-9 (1994) [hereinafter lmplicit Marginal Tax Rates]; David A. Super et al., Ctr. on Budget \& Policy Priorities, Warning: 1nadequate Low-lncome Subsidy Design Can Cause Problems for Health Care Reform x-xiii (1994).

193. To be sure, another possibility would be to impose stricter financial eligibility conditions. This could result in phasing out the same benefit over a shorter range of incomes, increasing implicit marginal tax rates. See 1mplicit Marginal Tax Rates, supra note 192 , at $7-9$. 
stay within their cap have led to frequent, unexplained changes in the program's rules, the claimant may suspect that the rules are in fact a sham and that favoritism rather than compliance is what matters.

Other economic analyses of public benefit programs' impact are likely to depend on assumptions that a program is or is not a responsive or functional entitlement and to become problematic when those assumptions are not met. For example, Judge Posner criticizes the inefficiencies that result from differences in the generosity of public benefit programs. ${ }^{194}$ In addition to arguing that society as a whole loses when low-income families move to high-benefit states for no useful economic purpose, he also finds that low-income families as a group also lose because more claimants must share a fixed relief budget in the destination state. ${ }^{195}$ This assumes that the destination state imposes a hard cap on its spending for benefits rather than operating a more flexible responsive entitlement. More particularly, it assumes that spending on relief is perfectly inelastic relative to changes in the liberality of the program-that the supply curve in Figures I-7, above, is vertical. While possible, this seems unlikely.

A more realistic assumption would have yielded a more ambiguous story. If the political system in the new state accepted the increase in demand, average benefit levels would stay constant and the low-income population as a whole would not lose. If, on the other hand, the destination state resented the influx of claimants-if the supply function for benefits remained unchanged-the liberality of the benefit program would decline to reach a new equilibrium. The aggregate amount of benefits distributed, however, would rise as the public becomes more willing to support the program as it adopts stricter rules.

Judge Posner also assumes that low-benefit states will be "encourage [d]" in their parsimonious policies by the outflow of claimants. ${ }^{196}$ Here, he effectively assumes that the supply of benefits in these states is completely elastic relative to the liberality of the program-that while the supply curves for benefits in generous states are completely vertical, the more miserly states' supply curves are horizontal. 197 These assumptions are exceedingly difficult to reconcile; if anything, one might expect somewhat more elasticity in a high-benefit state. A more realistic view would have the demand curves shifting to the left in the low-benefit state as a result of the out-migration, resulting in some liberalization in the program that partially offsets the decline in participation. Eventually, with

194. Posner, supra note 143 , at $675-76$.

195. Id.

196. Id. at 675 .

197. Put another way, Posner assumes that the high-benefit state operates with a completely fixed budget for benefits which it divides up among whatever claimants appear at its doors but that the low-benefit state pockets any savings from out-migration rather than giving each remaining claimant larger benefits as its relative share of the pie increases. It is unclear why this would be so. 
increased demand driving down effective benefit levels in generous states and declining demand allowing liberalizations in low-benefit states, one could imagine the gap between the two shrinking. Over time, the states' policies might converge to the point that, after accounting for differences in living costs, the increase in benefits families would reap from moving would no longer offset their moving costs and the value of the informal supports (e.g., child care from relatives) they would be leaving behind in the low-benefit state. In fact, this already appears to be the case. ${ }^{198}$

2. Targeting Effects. - Responsive entitlements also produce positive distributional effects, helping to target society's resources better on those most in need. They improve targeting both of society's overall fiscal policies and of that subset serving low-income people.

For many types of benefits, a responsive entitlement is the only conceivable method of administration. Tax expenditures operate as responsive entitlements since no one could determine and pay his taxes if the availability of a deduction or credit depended on a subsequent discretionary decision by a tax administrator. ${ }^{199}$ Similarly, administering a participation cap on the large middle-class benefit programs such as Social Security and Medicare would be both politically and administratively inconceivable. Thus, a disproportionate share of the programs that could plausibly operate without responsive entitlements are those that focus on low-income people. This suggests that, if the polity turns against responsive entitlements, the impacts of enrollment caps, arbitrary deci-

198. Posner was commenting on durational residency requirements of the kind struck down in Shapiro v. Thompson, 394 U.S. 618, 638 (1969), as a "crude and only partially effective" response to the incentives to move that differential benefit levels create. Posner, supra note 143, at 676. In Saenz v. Roe, 526 U.S. 489, 506-07 (1999), the Court reaffirmed and strengthened Shapiro's result, striking down policies that provided reduced grants (rather than none at all) to people traveling between states. In fact, extensive evidence presented in the Saenz litigation suggests that differences in benefit levels do not appear to play a significant part in low-income people's decisions to move. Roe v. Anderson, $966 \mathrm{~F}$. Supp. 977, 981-82 (E.D. Cal. 1997) (discussing evidence submitted in support of lower court's order ultimately affirmed in Saenz). The loss of informal supports-spot babysitting, emergency loans, and companionship-from friends and family, the cost of moving, and the often higher cost of living in states with higher benefit levels all tend to offset the difference in benefit levels.

199. According to Price Waterhouse's budget expert Stanley Collender, proposals for tax expenditures "would be politically unacceptable if they were framed as the new entitlements that they really are." Steven Pearlstem \& Clay Chandler, Tax Reform Falling Prey to Tax Cuts: In Political Battle, Economics Loses Out, Wash. Post, Dec. 18, 1994, at A1 (quoting Collender). See generally, Senate Comm. on the Budget, 104th Cong., Tax Expenditures: Compendium of Background Material on 1ndividual Provisions (Comm. Print 1996) (cataloging rules forgoing tax revenues otherwise owing in order to reward, assist, or provide incentives to various groups and behaviors). One exception is the "demonstration project" in medical savings accounts (MSAs), which generally makes the tax benefits of contributing to those accounts unavailable to new claimants after 750,000 taxpayers have done so. Id. at 422 . Since the number claiming MSA tax preferences has never approached this threshold, the administrative and equity issues that could then arise have gone unexplored. 
sionmaking, and the general inefficiency of the nonentitlement structure will be borne disproportionately by low-income people.

In addition, the lack of a responsive entitlement is likely to misallocate resources even within the low-income population. Persons needing assistance during economic booms will be treated more generously than those suffering along with many others during recessions. Since help from friends, relatives, and private charities also may be more available during periods when most are prospering, this redistribution seems difficult to justify. Conversely, a responsive entitlement redistributes resources from persons in prosperous times to those needing help during recessions. ${ }^{200}$

\section{Macreconomic Effects of Responsive Entitlements}

A responsive entitlement can act as an automatic stabilizer, stimulating the economy with additional spending during downturns and shrinking back when conditions improve. ${ }^{201}$ As the number of poor and unemployed people rises, claims for food stamps and unemployment compensation increase. ${ }^{202} \mathrm{ln}$ addition, in a slack economy, more older workers will elect to retire and begin drawing Social Security and Medicare. Moreover, during regional recessions, responsive entitlements automatically target additional spending on distressed areas without wasting money on regions that continue to prosper.

In theory, Congress could increase spending for programs with capped enrollment or funding to compensate for recessions. In practice, this rarely works well. The administration's party may delay the relief because it fears being blamed for any downturn it admits is taking place. Relief may be delayed further by battles over the form it should take and which levels of government should control the funding. ${ }^{203}$ Moreover,

200. If the program's rules remain constant, this redistribution will achieve equality of treatment between the two groups. As discussed supra Part II.A, however, society may be more willing to help people during recessions. If the supply curve for benefits shifts farther to the right than the demand curve, some liberalization of the program's rules may be possible on behalf of those needing aid during a recession.

201. See, e.g., Kondratas, supra note 6, at 6-7 (“[T]he [food stamp] program has ... served to mitigate the effects of regional recessions by increasing federal transfer payments in such regions precisely at the time necessary to produce the greatest countercyclical effects); Food Stamps, supra note 12, at 3 (explaining how the food stamp program expands during recessions and contracts during economic recoveries).

202. See, e.g., Randy Rosso, Mathematica Policy Research, Characteristics of Food Stamp Households: Fiscal Year 2001, at 11 (2003), available at http://www.mathematicampr.com/pdfs/2001charreport.pdf (on file with the Columbia Law Review) (showing that the number of food stamp participants, persons in poverty, and unemployed persons all track changes in macroeconomic performance).

203. During each of the last two recessions, by the time Congress and the President could agree upon an extension of unemployment insurance benefits, the recession was technically over. See Job Creation and Worker Assistance Act of 2002, Pub. L. No. 107-147, tit. II, 116 Stat. 21, 26 (creating temporary extended unemployment compensation program in response to recession of 2001); Emergency Unemployment Compensation Act 
much of the spending resulting from increased caps is likely to be mistargeted where a downturn has hit some parts of the country more than others: Even if only some states are in distress, all are represented in Congress and will want "their share" of any new spending. Finally, the "emergency" spending may be difficult to end once the economy turns around since the recipient programs will try to claim it as part of their baselines.

\section{E. Conclusion}

The complexity of a given program's eligibility conditions is a function of a variety of political and policy factors. The more complex a system is, the greater the administrative cost, both to agencies ${ }^{204}$ and to claimants. ${ }^{205}$ Whatever level of complexity society might otherwise settle upon, however, is likely to increase substantially if it must ration benefits among an excess of claimants drawn to the program by eligibility rules more liberal than society is prepared to extend. These rationing systems also misallocate scarce resources among competing claimants much as systems to ration price-controlled goods tend to steer those goods to buyers that value them less than other prospective buyers. Constraining participation with eligibility rules rather than caps-maintaining a responsive entitlement-will both reduce the share of the program's resources required for administration and allocate benefits to those most in need. By making the receipt or non-receipt of benefits more predictable, responsive entitlements also help programs better calibrate incentives for claimants. "Responsive entitlements also allow faster and more accurate adjustments to the business cycle, to diverging conditions among regions, and to other changes in the extent of need than does relying on the political process to make those adjustments manually.

Responsive entitlements often will not be the most appropriate model for programs whose primary purpose is to build capital for society-such as pilot programs to develop knowledge about how a particular program design works or educational programs to build a corps of people trained in a particular trade or profession-but offer a clearly superior

of 1991, Pub. L. No. 102-164, tit. I, 105 Stat. 1049, 1049 (establishing emergency unemployment compensation program in response to recession of 1990-1991); Nat'l Bureau of Economic Research, Business Cycle Expansions and Contractions (2003), at http://www.nber.org/cycles (last visited Feb. 24, 2004) (on file with the Columbia Law Review) (estimating that the recession of 1990-1991 ended in March 1991 and that the recession of 2001 ended in November 2001); 47 Cong. Q. Almanac 301-10 (1991) (describing tortuous political history of the 1991 extension of unemployment compensation). Similarly, President Clinton's proposed 1993 "stimulus package," which targeted resources on cities, faced sufficient opposition from state-oriented Republicans that it stalled in the Senate until evidence of strong economic recovery mooted the case for it. 49 Cong. Q. Almanac 706-09 (1993).

204. Super, Offering an Invisible Hand, supra note 121, at 852-53.

205. 1d. at 832-36. 
means of administering programs whose primary purpose is to benefit their recipients.

Functional entitlements offer significant efficiency advantages of their own. Particularly where legal or practical considerations limit beneficiaries' ability to supplement the benefit they receive, programs that provide benefits inadequate to purchase a good or service on the open market risk creating a shadow market for a highly inferior version of that good or service. That market will function badly because demand will be almost completely elastic with respect to price increases above the amount of the subsidy. Alternatively, a different set of inefficiencies are likely to result from claimants' attempts to supplement the benefit illicitly.

Significantly, this argument for entitlement structures assumes that society is able to express its policy preferences at least as well through eligibility rules and the articulation of functional goals for programs as through caps on participation and benefits-that is, that setting the strictness of eligibility rules or setting the size of a program cap are both effective means by which society can convey how generous it is willing to be in providing a particular benefit. The next section tests that assumption. 1t finds that entitlement structures in fact are not just adequate but clearly superior vehicles for transparent political debate.

\section{I1. The Politics of Entitlements}

The choice between entitlement and nonentitlement structures also has significant implications for the transparency of the political debate concerning a program. Most familiar, perhaps, are arguments that positive entitlements empower unelected judges to make policy in disregard of the political process's wishes. Part 1Il.A briefly examines this argument. It finds little evidence of a serious threat to democratic legitimacy and indeed some reason to believe that legally enforceable rights are essential to keeping the political process relevant.

More broadly, this section finds that, in addition to creating serious inefficiencies in the economic sphere, the lack of entitlement structures can create troubling political inefficiencies as well. Specifically, as Part llI.B explains, responsive, functional, and relatively unconditional entitlements are far easier to describe intelligently and reliably to the general public and hence foster political transparency. By contrast, nonentitlement programs are more difficult for the public to monitor and are much more likely to produce results that differ significantly from what the public believes it is supporting.

Part III.C then discusses two important ways in which this difficulty has distorted the political treatment of these programs, further obscuring these programs' policies. As a result, nonentitlement programs have 
fared less well in the political process. ${ }^{206}$ Finally, as Part III.D explains, these distortions have led many actors to take political positions toward entitlement that ill-reflect their professed values.

\section{A. Positive Entitlements and Democratic Legitimacy}

Before addressing the effect that the lack of responsive and functional entitlement structures (and relatively conditional programs) have on political debates, it is necessary to consider whether the legal structures that often accompany these kinds of entitlements are antithetical to democratic governance. Both liberal and conservative politicians have criticized public benefits litigation under positive entitlements as improperly arrogating policymaking authority from elected officials. ${ }^{207}$ These complaints offer a possible justification for stripping public benefits claimants of positive entitlements: the restoration of democratic legitimacy. This argument, however, does not bear close scrutiny.

First, it should be noted that some of these specific accusations may be somewhat disingenuous: The critics, rather than the courts, may be the ones deviating from the original intent of the legislation. ${ }^{208}$ Thus, some politicians may accuse the courts of twisting legislative intent to allow themselves to claim that they are only restoring the program to its agreed-upon rules rather than having to carry the burden of persuasion on the merits of their proposed change. In effect, they argue that a prior legislature considered the merits of their proposal so current policymakers need not.

More generally, the enforcement of entitlements can serve an important democracy-enhancing purpose. Litigation enforcing responsive or functional entitlements typically seeks to enforce promises made in legislation or administrative rules. ${ }^{209}$ If those promises have become unwork-

206. As with the economic analysis above, this section focuses on responsive, functional, and relatively unconditional entitlements (and their opposites). Other types of entitlements also generate important political issues. See, e.g., Stephen F. Williams, Liberty and Property: The Problem of Government Benefits, 12 J. Legal Stud. 3, 13-14 (1983) (arguing that the binary nature of legal entitlement theory creates perverse incentives for government to avoid setting firm rules for programs).

207. See, e.g., H.R. Rep. No. 95-464, at 246 (1977), reprinted in 1977 U.S.C.C.A.N. 1978, 2191 (describing Food Stamp Act of 1977, wbich dramatically liberalized food stamp eligibility, as also designed to prevent policy from being made through claimants' litigation); James Graham, The Enemies of the Poor 121 (1970) (describing the outrage of then-Governor Reagan and West Virginia Democratic Senator Robert Byrd over legal services litigation on public benefit programs).

208. Indeed, the question of whether the courts sbould even try to ascertain legislative intent is intensely controversial far beyond the bounds of public benefits law. See, e.g., Antonin Scalia, A Matter of Interpretation 16-18 (1997) (critiquing role of legislative intent in statutory interpretation).

209. See, e.g., Mitchell v. Johnston, 701 F.2d 337, 346-47 (5th Cir. 1983) (enforcing Medicaid statute's commitment to cover all necessary medical care for cbildren through its early and periodic screening, diagnosis, and treatment (EPSDT) component); Rodway v. U.S. Dep't of Agric., 514 F.2d 809, 818 (D.C. Cir. 1975) (enforcing commitment in Food 
able or inadvisable for any reason, a proposal to amend or repeal them allows far more open debate about the available alternatives than an agency's covert non-compliance ${ }^{210}$ or appropriators' quiet shorting of a program's funding. ${ }^{211}$ Some courts' aggressive efforts to construe eligibility conditions narrowly may sometimes produce results that the political process did not intend. They are not outliers in this regard. For example, numerous interpretive presumptions that courts have imposed on legislatures for a variety of policy purposes openly disavow efforts to determine the actual will of the democratic process. ${ }^{212}$ Moreover, on other occasions, litigation narrowing or expanding eligibility may facilitate democratic choice by forcing the political branches to make explicit their desire to grant or deny benefits to a particular group of claimants. ${ }^{213}$ Most importantly, legislators can readily override these decisions; little evidence suggests that courts willfully resist legislative efforts to override their decisions. ${ }^{214}$

Nor do positive entitlements lead to litigation that raises serious issues of institutional competence. Litigation seeking to enforce respon-

Stamp Act of 1964, as amended in 1971, to provide a nutritionally adequate diet); Robertson v. Jackson, 766 F. Supp. 470, 476 (E.D. Va. 1991) (finding that lack of resources does not excuse state agency's noncompliance with federal law).

210. See Super, Offering an lnvisible Hand, supra note 121, at 839-42 (discussing policy implications of invisibility of informal rationing systems).

211. For example, whatever one's perspective on taxes, one could hardly argue that a country with feeble enforcement of tax laws operates in a more democratically legitimate manner than one in which candidates run on anti-tax platforms and then amend the laws to reduce taxes upon winning office.

212. See, e.g., Gregory v. Ashcroft, 501 U.S. 452, 460-61 (1991) (requiring a plain statement to construe anti-discrimination law as impinging upon traditional areas of state sovereignty); EEOC v. Arabian Am. Oil Co., 499 U.S. 244, 248-51 (1991) (presuming Congress did not intend anti-discrimination laws to apply overseas absent a very plain statement to the contrary).

213. The classic example of this is King v. Smith, 392 U.S. 309, 333-34 (1968), which struck down state rules denying AFDC to women receiving frequent male visitors. The federal agency responsible for AFDC had issued a memo several years earlier finding that these "man in the house" rules were unlawful but had failed to enforce that interpretation. Prior to Smith, this issue was difficult to join politically at the federal level: Legislation to outlaw these rules would be redundant with the agency's memo, yet proponents of those rules had no reason to propose legislation since the memo was not being enforced. After Smith, proponents had a clear reason to seek legislation reinstating "man in the house" rules. Their inability even to start moving legislation rendered a clear political verdict against those rules.

214. Compare, e.g., Shea v. Vialpando, 416 U.S. 251, 264 (1974) (interpreting statute to exclude moneys not actually available to a family from consideration in AFDC's means test), with Heckler v. Turner, 470 U.S. 184, 199-200 (1985) (unanimously abandoning the actual availability principle in light of a contrary provision of the Omnibus Budget Reconciliation Act of 1981); compare also Lewis v. Grinker, 965 F.2d 1206, 1214-15 (2d Cir. 1992) (finding undocumented women eligible for prenatal coverage in Medicaid despite statutory language that concededly suggested the opposite outcome), with Lewis $v$. Thompson, 252 F.3d 567, 580, 589 (2d Cir. 2001) (vitiating earlier orders in response to PRWORA's clear prohibition on providing non-emergency Medicaid to undocumented immigrants). 
sive entitlements or challenging eligibility conditions typically calls for legal analysis of the kind that is common in administrative law-and typically subject to Chevron ${ }^{215}$ deference, making claimants unlikely to win except where they have very strong cases. ${ }^{216}$ Challenges to agencies' compliance with functional entitlements may require judicial fact finding, but this, too, is constrained by the Administrative Procedure Act. ${ }^{217}$

\section{B. The Innate Lack of Transparency of Nonentitlement Programs}

With neither a functional nor a responsive entitlement, a public benefit program is likely to be almost impossible to describe meaningfully to the general public. "We give some money to some senior citizens" may be accurate, but it provides no basis for even the most tentative assessment of the merits or adequacy of the program. Saying "we provide some food assistance to some low-income people" conveys that the benefit is provided for an undeniable human need and that it is means-tested, but does little more than that. The same phrase could apply equally to the food stamp program, serving over twenty-one million people in an average month, ${ }^{218}$ and a one-time giveaway of surplus cheese. Few viable alternatives are available for describing the scope of a program that is not a responsive entitlement or the purpose of a program that is not a functional entitlement. ${ }^{219}$

215. See Chevron U.S.A. Inc. v. Natural Res. Def. Council, Inc., 467 U.S. 837, 844 (1984) (" $[\mathrm{C}]$ onsiderable weight should be accorded to an executive department's construction of a statutory scheme it is entrusted to administer . . . ").

216. See, e.g., Alexander v. Glickman, 139 F.3d 733, 736 (9th Cir. 1998) (deferring to agency policy denying food stamp eligibility to households with vehicles in which they held no equity despite legislative history and contemporaneous agency construction indicating that such vehicles were exempt).

217. 5 U.S.C. $\$ 706(2000)$.

218. Database Monitoring Branch, U.S. Dep't of Agric., Program Information Report tbl.2 (2003).

219. This difficulty in articulating meaningful differences between policy choices in nonentitlement programs is also a serious impediment to litigation concerning these programs. The U.S. Supreme Court has largely foreclosed such litigation under the federal Constitution, e.g., Schweiker v. Wilson, 450 U.S. 221, 234-35 (1981) (reaffirming that only a "reasonable basis" is required when Congress makes classifications in social welfare programs such as Medicaid), but the problem remains where state courts have interpreted their constitutions' equal protection clauses more broadly. See generally Helen Hershkoff, Positive Rights and State Constitutions: The Limits of Federal Rationality Review, 112 Harv. L. Rev. 1132, 1144-53, 1168-83 (1999) (suggesting that many factors constraining federal courts from scrutinizing social welfare program rules closely do not apply to state courts interpreting their own constitutions). The most actively litigated state constitutional declaration of welfare rights is Article XVII, Section 1, of the New York Constitution, which provides that " $[t]$ he aid, care and support of the needy are public concerns and shall be provided by the state and by such of its subdivisions, and in such manner and by such means, as the legislature may from time to time determine." N.Y. Const. art. XVII, $\S 1$. This language appears to create a responsive entitlement, see, e.g., Tucker v. Toia, 371 N.E.2d 449, 451-53 (N.Y. 1977) (finding that "section 1 of article XVII imposes upon the State an affirmative duty to aid the needy"), but the New York courts have relied on the reference to the legislature to reject most claims of functional 
This difficulty in describing nonentitlement programs systematically skews political debates about them. In particular, it greatly complicates advocacy for expanding or preserving such programs and provides opportunities for dedicated opponents to maneuver program reductions going far beyond what policymakers and voters think they are approving. These problems thus should be of concern to supporters of social programs across the political spectrum.

1. Responsive Entitlements. - The obvious way to describe a program that is not a responsive entitlement is in terms of the number of people or families it serves. For communicating with the general public, or even most policymakers, this is unlikely to be terribly meaningful. Even among those that have devoted their lives to working for low-income people, few likely could state within the nearest five million the number of people in the United States living below the poverty line. ${ }^{220}$ Thus, knowing, for example, that the food stamp program serves between twenty-one and twenty-two million people in an average month is unlikely to convey very much to most people. ${ }^{221}$

entitlement. See, e.g., Bernstein v. Toia, 373 N.E.2d 238, 244 (N.Y. 1977) (holding that Article XVII applies only "to questions of impermissible exclusion of the needy from eligibility for benefits, not to the absolute sufficiency of the benefits distributed to each eligible recipient"); Hershkoff, supra, at 151-52 (noting that New York courts are deferential to legislative decisions regarding the adequacy of benefits provided). But see Fulton v. Krauskopf, 484 N.Y.S.2d 982, 984 (Sup. Ct. 1984) (finding a functional entitlement to funds sufficient to allow homeless parents to pay transit fare to escort their children to school). As for eligihility conditions-in essence the legislature's ability to restrict who is deemed "needy" or what steps they must take to obtain aid-the courts' boldings have been quirky. Compare Aliessa v. Novello, 754 N.E.2d 1085, 1088 (N.Y. 2001) (striking down restrictions on immigrants' eligibility for Medicaid), with Alvarino v. Wing, 690 N.Y.S.2d 262, 263 (App. Div. 1999) (upholding similar restrictions on immigrants' eligibility for state-funded food assistance). The overall result of this effort to define constitutional welfare rights without functional entitlements or clear standards for how conditional those rights may be made has been mixed.

220. For 2002, the latest year for which the Census Bureau has released data, that number is 34.6 million, up three million from two years before. Ctr. on Budget \& Policy Priorities, Poverty Increases and Median Income Declines for Second Consecutive Year (Sept. 29, 2003), available at http://www.chpp.org/9-26-03pov.htm (on file with the Columbia Law Review). Since 1978, when it was at 24.5 million, that number soared to 39.3 million in 1993 and then began to decline slowly until the recent recession. 2000 Green Book, supra note 134 , at I285.

221. This measure, and others like it, tend to be complicated by numerous other factors that most policymakers and the vast majority of the general public would not anticipate and would have difficulty evaluating even if they were pointed out. For example, if told the number of people in poverty and the number receiving food stamps in an average month, the average person's natural tendency would be to compare the two. Such a comparison could be deceptive: The Census Bureau measures poverty on an annual basis, but food stamp eligibility is determined monthly. Many families whose annual income exceeds the poverty line are poor for some months. Also, the number of food stamp recipients includes a modest number above the poverty line. And although 21.3 million people received food stamps in an average month in federal fiscal year 2003, the number receiving food stamps at some point during that year was roughly fifty percent higher hecause of the constant turnover in the rolls. See Philip Gleason, et al., 
Describing programs in financial terms is likely to be even less meaningful. Evaluating a program's budget requires knowledge of at least three factors, none of which is likely to be within the command of any but fairly sophisticated audiences: the size of the population needing the benefit, the average cost of the benefit, and the program's administrative costs. In a country as large as ours, virtually any program's budget will sound impressive. The 2002 farm bill provided $\$ 80$ million over six years for a tiny, basically insignificant farmers' market nutrition program. ${ }^{222}$ Yet most voters' only real frame of financial reference is their own family budget, which is obviously inadequate to evaluate even figures far short of $\$ 80$ million.

When a program is described in terms of its current participation or budget, the most common point of comparison is its participation or budget in a prior year. This can be highly misleading, however, because eligibility and need are likely to change sharply over time. Comparisons also often neglect the effects of inflation. ${ }^{223}$ Thus, opponents of the food stamp program asserted that it was growing "out of control" when several million economically displaced people began receiving benefits immediately before, during, and after the recession of the early 1990 s. $^{224}$ In fact, it would have been more convincing evidence of problems in design or

Mathematica Policy Research, The Dynamics of Food Stamp Program Participation in the Early 1990s 58 (1998), available at http://www.fns.usda.gov/oane/MENU/published/ FSP/F1LES/Participation/Dynamics.pdf (on file with the Columbia Law Review) (finding that over half of all food stamp households left the program within six months in the economically prosperous 1980 s while over half left within nine months in the more depressed early 1990s).

For what it is worth, the average monthly number of people receiving food stamps in 1994 and 1995 was equal to $72 \%$ and $73 \%$, respectively, of the number of families in poverty those years. U.S. Census Bureau, Historical Poverty Tables, tbl.2 (2003), available at http://www.census.gov/hhes/poverty/histpov/hstpov2.html (on file with the Columbia Law Review); Tabulated Keydata Reports, supra note 129. That ratio had dropped to $54 \%$ by 2000. U.S. Census Bureau, supra, tbl. 2; Tabulated Keydata Reports, supra note 129. Over the same period, USDA estimates that the food stamp participation rate-the percentage of eligible people receiving food stamps in an average month-fell from $\mathbf{7 4 . 8 \%}$ in 1994 to $57.9 \%$ in 1999 before rebounding slightly in 2000 to $59.3 \%$. Karen Cunnyngham, Trends in Food Stamp Program Participation Rates: 1994 to 2000, at 10 (2002), available at http://www.mathematica-mpr.com/PDFs/trends.pdf (on file with the Columbia Law Review)

222. Food Stamp Reauthorization Act of 2002, Pub. L. No. 107-171, § 4402, 116 Stat. 134,334 .

223. See, e.g., 141 Cong. Rec. 8506 (1995) (statement of Rep. Richardson) ("Republicans have been claiming they are not really cutting the School Lunch Program ... [but t] heir supposed spending 'increases' don't take into account rising food costs, inflation, or increases in number of kids who need the program.").

224. See, e.g., id. at 24,559 (statement of Sen. Ashcroft) (attributing "exponential[ ]" increase in food stamp spending to "fraud and abuse, compounded by oversight"). 
management had the program failed to shrink rapidly when the economy recovered. 225

Probably the best way to describe a program that is not a responsive entitlement is in terms of the percentage of eligible people or families that it serves. Little technical sophistication is required to comprehend the qualitative difference between a program reaching five percent of those eligible and one that serves over eighty percent of potential beneficiaries. Estimating those ratios, however, is rarely straightforward. ${ }^{226}$ Measuring the percentage of applicants served or the average time on a waiting list, for example, ignores potential claimants who do not bother to apply because they know a program is oversubscribed. On the other hand, assuming that all eligible persons would receive benefits if they were freely available also does not make sense: Even in well-established responsive entitlements such as food stamps and SSI, a significant share of the eligible population never applies. ${ }^{227}$ Also, some eligibility requirements' impact on the size of the eligible population can be difficult or impossible to estimate. Thus, few programs have a widely accepted participation rate and for virtually none is this figure included in many public discussions of the program. When the public reads media stories about WIC and federal housing assistance programs, it has no way of knowing that the former serves over eighty percent of eligible claimants ${ }^{228}$ and the latter about a quarter. ${ }^{229}$

In the absence of any intelligible basis for understanding programs differently, the news media and its public-as well as even many policymakers and analysts who ought to know better-tend to assume that programs operate as responsive entitlements. ${ }^{230}$ For the public, this assump-

225. In fact, food stamp participation dropped by about forty percent-about eleven million people-from its peak in March 1994 until its trough in 2000, prior to the recent recession.

226. See, e.g., Laura A. Castner \& Allen L. Schirm, Mathematica Policy Research, Empirical Bayes Shrinkage Estimates of State Food Stamp Participation Rates for 1998-2000: Final Report 7 (March 2003), available at http://www.mathematica-mpr.com/ PDFs/empbay2000.pdf (on file with the Columbia Law Review) ("[D]irect sample estimates of participation rates are relatively imprecise.”); National Research Council, Estimating Eligibility and Participation for the WIC Program 21-29 (Michele Ver Ploeg \& David M. Betson eds., 2001), available at http://www.nap.edu/books/0309075904/html/R1.html (on file with the Columbia Law Review) (outlining current methods for estimating eligibility and full-funding participation).

227. See Karen Cunnyngham, Mathematica Policy Research, Trends in Food Stamp Program Participation Rates: 1999 to 2001, at $6 \mathrm{n} .8$ (2003), available at http:// www.fns.usda.gov/oane/MENU/published/FSP/F1LES/Participation/Trends1999-

2001.pdf (on file with the Columbia Law Review) (asserting that individuals who leave TANF often are unaware of their continuing eligibility for food stamps).

228. See 2000 Green Book, supra note 134, at 961.

229. Ctr. on Budget \& Policy Priorities, Introduction to the Housing Voucher Program 2 (2003), available at http://www.cbpp.org/5-15-03hous.pdf (on file with Columbia Law Review).

230. The same erroneous assumptions cause the media and the public, sometimes encouraged by politicians, to assume that private charities operate as responsive 
tion makes sense: If a benefit is worth providing, why would it be worth providing to only some of those determined to need it? Conversely, if large portions of the population deemed to need the benefit are getting by without it, perhaps the benefit is not so important after all.

More sophisticated observers similarly assume that programs operate as responsive entitlements because serious discussion is difficult or impossible without doing so. The issue of declining cash assistance caseloads is a case in point. The broad political coalition that enacted PRWORA was united in its rejection of AFDC but did not have a common vision of what should take its place. If the law's goal was simply to stop providing checks to families, it could have prohibited states from doing so with federal funds. Similarly, if the goal was to reduce the number of checks provided, it could have capped the number of families that could receive checks. Yet neither PRWORA nor any major welfare bill introduced in the I03d or I04th Congress did so. ${ }^{231}$ Explicitly announcing that families in need would be denied basic subsistence assistance simply because some arbitrary quota had been met was a far harsher policy than almost anyone was prepared to sell to the public. The public was told that caseloads would decline as a result of positive efforts to help recipients find alternatives. ${ }^{232}$ After PRWORA passed, its supporters treated declin-

entitlements. See Janet Poppendieck, Sweet Charity? Emergency Food and the End of Entitlement 210-13 (1998) (discussing emergency food recipients' frustration with insufficient quantity of food provided by private charities).

231. All but a handful of House Republicans in the 103d Congress co-sponsored a comprehensive welfare bill introduced by House Minority Leader Michel. See H.R. 3500, 103d Cong. (1993). It would have imposed extensive new work requirements, given states the option to convert AFDC into a block grant, authorized states to deny benefits on numerous new grounds, and capped spending on means-tested programs. Id. $\S \S 101-103$, 301-306, 309, 901, 904, 701-702. It did not, however, limit the number of families that could receive welfare checks. Indeed, it would have imposed penalties on states that took the AFDC block grant and then used the funds for any purpose other than paying cash grants to families. Id. $\$ 301$.

The most conservative major proposal in the 103d Congress probably was the bill introduced by Sen. Lauch Faircloth and Rep. James Talent and co-sponsored by, among others, Senate Republican Leader Robert Dole and future House Speaker J. Dennis Hastert. S. 2134, 103d Cong. (1994); H.R. 4566, 103d Cong. (1994). It would have eliminated programs, capped funding, and imposed severe work requirements. S. 2134, $\$ \$ 603,601,101$. This legislation did not, however, include any limits on the number of families states might assist. Indeed, even its time limit was only a state option. Id. $\$ 501$.

When they took control of Congress in the 1994 elections, Republicans' time increasingly was consumed with working on legislation moving towards enactment. As a result, fewer Republicans introduced their own separate welfare bills. Again, the most conservative was probably Sen. Faircloth's, again with Sen. Dole's co-sponsorship. S. 834, 104th Cong. (1995). This bill, like its predecessor, emphasized the dissolution of programs, constraining funding, and imposing demanding work requirements. Id. $\$ \S 112$, 101,213 . It, too, would impose no limit on the number of families that could receive checks.

232. See, e.g., Danny Westneat \& Kery Murakami, State Lags in Welfare CutsLegislature About to Play Catch-Up, Seattle Times, Feb. 27, 1997, at A1 (quoting 
ing caseloads as a measure of success, ${ }^{233}$ implying that it was still a responsive entitlement. ${ }^{234}$ The law's drafters plainly recognized the importance of responsive entitlements: They relied on changes in participation in the food stamp program-still a responsive entitlement-to measure increased need in states, triggering the TANF contingency fund. ${ }^{235}$

The mistaken assumption that a program is a responsive entitlement weakens the program's supporters politically in efforts both to preserve and to expand the program. Expanding such programs can be very difficult. Getting the public excited about doing something that it thinks it is already doing is not easy. This is particularly true when budgetary limitations mean that, even if enacted, the proposed program still will serve only a fraction of those determined eligible. On the other hand, the difference between meeting one-quarter of need and one-fifth of need hardly sounds like an issue of principle.

Someone generally disinclined towards means-tested programs might welcome the political difficulties that the lack of a responsive entitlement status imposes on a program's supporters. That approach, however, ignores the serious inefficiencies that result. The liabilities a particular program may have in garnering support are not likely to affect the overall level of public support for social spending. Instead, they will tend to shift that spending from the consolidation and improvement of existing programs into the creation of new ones. If the same amount of money will modestly increase the percentage of eligible families receiving housing subsidies or fund the creation of a new (nonentitlement) program for the homeless, the political benefit of the latter approach may be far more apparent. Multiplying the number of programs will, of course, increase the number of bureaucracies that must be funded to operate them. And, as shown above, those will be relatively costly bureaucracies

commentators who suggest that work requirements are responsible for reduced welfare roles).

233. E.g., Robert Rector, Comment, in The New World of Welfare 265-66 (Rebecca M. Blank \& Ron Haskins eds., 2001) (discussing Wisconsin's experience of declining welfare caseloads with no increase in child poverty).

234. In fact, it appears that most states operated TANF-funded cash assistance programs as responsive entitlements, at least until the recession of 2001 and the slack economy that followed sapped states' revenues and wiped out their accumulated TANF surpluses. The fallacy in assuming that sharply declining caseloads reflected equally sharp declines in need therefore is a more subtle one: a failure to appreciate the impact of an increase in conditionality of cash assistance benefits. After modest increases around the beginning of the recession, cash assistance caseloads have become essentially static despite substantial increases in unemployment and poverty. This apparent mismatch between need and participation may reflect additional increases in the conditionality of benefitsespecially as time limits begin to affect significantly more people-or may indicate that some administrators are using the discretion PRWORA granted them to impose de facto caps by ratcheting up the conditionality of their programs steeply as participation exceeds desired levels. See Super, Offering an Invisible Hand, supra note 121, at 847-48 (linking declining cash assistance caseloads to informal rationing).

235. 42 U.S.C. $\$ 603$ (b) (6) (B) (2000). 
since they must ration benefits among an overadequate number of suitors. Finally, the lack of a responsive entitlement is likely to force society to make a series of apples-against-oranges decisions in allocating the limited supply of funds, weighing coverage for a higher fraction of the eligible population against eliminating eligibility conditions of questionable merit (or improving the quality or quantity of benefits). These sorts of decisions are often made inefficiently, almost randomly, depending on whether the media or the courts focus on people disadvantaged by a particular eligibility condition or limitation on the value of benefits or on those mired on a waiting list. ${ }^{236}$

2. Functional Entitlements. - For the same reasons it is difficult to explain just who does and does not get a benefit when a program does not operate as a responsive entitlement, the functions of programs that are not functional entitlements are commonly misunderstood. The difference between providing very little help and coming close to meeting a claimant's needs is difficult to express simply. The agriculture committees cut the food stamp program $\$ 600$ million more deeply in PRWORA than the Republican leadership required ${ }^{237}$ so that they could buy commodities for the Emergency Food Assistance Program (TEFAP), which aids food banks and soup kitchens. ${ }^{238}$ The food stamp program, at least until PRWORA, came relatively close to being a functional entitlement; the emergency food network commonly provides families with only a few days' food every few months. Yet the programs were seen as largely equivalent: Both feed people.

A program that is not a functional entitlement will be open to a range of damaging criticisms. If it is simply replacing expenditures that a family would have to make anyway-as, arguably, LlHEAP does-its nexus with the service it nominally provides comes open to question and critics will insist that it is just a "welfare" program in disguise ${ }^{239}$ Alternatively, if it is possible to get LIHEAP and still have one's utilities shut off or to receive food stamps and still be hungry, critics will complain that the programs are failures even though they were not designed to meet recipients' full needs-and may well be keeping utilities on longer, and recipient families fed better, than would otherwise be the case.

The impulse to assume a functional entitlement even in the absence of legal support may be even stronger than the urge to assume that all programs are responsive entitlements. Here again, the public is likely to

236. See, e.g., Clifford v. Janklow, 733 F.2d 534, 540-41 (8th Cir. 1984) (rejecting state criteria for targeting limited low-income home energy assistance funds on those most in need); Crawford v. Janklow, 710 F.2d 1321, 1328 (8th Cir. 1983) (same).

237. David A. Super, Working for Food: The Food Stamp Program as Model for a New Anti-Poverty Agenda, 78 N.Y.U. L. Rev. (forthcoming 2004).

238. 7 U.S.C. $\$ \S 612$ c, $2036(2000)$.

239. See Douglas J. Besharov, The Past and Future of Welfare Reform, Public Interest, Winter 2003, at 4, 17-18 (describing aid to working families "not receiving cash welfare" as "new welfare"). 
reason, if a problem is worth addressing at all, why would it be worth providing a benefit in an amount inadequate to solve the problem?240 Dissenting in Dandridge $v$. Williams, Justice Marshall complained that Maryland's ceiling on the size of AFDC grants, although nominally denying all benefits "with respect to needy dependent children in excess of four or five" was in fact a fractional reduction in all family members' benefits. ${ }^{241}$ "The result is that support for the entire family is reduced below minimum subsistence levels." ${ }^{242}$ Although correct about the practical effect of the cap, he had little basis for assuming that Maryland's underlying grant levels had any particular functional basis. ${ }^{243}$

Just as in the case of programs that are not responsive entitlements, champions of programs whose benefits are not functional entitlements have difficulty developing a stirring message in opposition to further diminution of the value of the programs' benefits. ${ }^{244}$ And unless funding is sufficient to put a full functional entitlement within reach, they can have little hope of rallying the masses in support of a "somewhat less inade-

240. "What good does it do to give an unwed mother a rent certificate if there are no apartments available?" asked the head of the research office of the U.S. Department of Housing and Urban Development (HUD), commenting on the inadequacy of the "fair market rents" that provide the benchmark for what landlords participating in Section 8 may receive. Clayton Jones, Plan for Direct Housing Aid to Needy May Entice Reagan Budget-Cutters, Christian Sci. Monitor, Jan. 6, 1981, at 4.

241. 397 U.S. 471,518 n.11 (1970) (Marshall, J., dissenting).

242. Id.

243. See Rosado v. Wyman, 397 U.S. 397,419 (1970) (declining to find a general duty to update AFDC benefit levels for inflation, much less to set them at any functionally defined level). The strength of the drive to find some measure of functional coherence is evident in cases such as Shea v. Vialpando, 416 U.S. 251 (1974), where courts labor to make one small facet of the benefit formula serve a functional purpose (e.g., accounting for all of a family's work expenses) even though tbe remainder of the benefit structure is largely within defendants' control and can easily be adjusted to offset the results of the court's ruling:

Congress thus sought to encourage AFDC recipients to secure and retain employment by requiring the States to take into account fully any expenses attributable to the earning of income in determining eligibility for assistance. . . . Standardized treatment of employment-related expenses without provision for demonstrating actual and reasonable expenses in excess of that standard amount, such as Colorado has adopted, threatens to defeat the goal Congress sought to achieve....

1d. at 264-65.

244. Even Justice Marshall's characterization of the cap in Dandridge as a complete denial of assistance to some family members, 397 U.S. at $518 \mathrm{n} .11$, invites trivial refutation: Maryland could amend its policy to provide an additional dollar for each additional child beyond the number that brings a family to the cap. To find this practically indistinguishable policy unconstitutional, plaintiffs again would have to persuade the Court to constitutionalize the setting of economy of scale adjustments. Thus, whether the deprivation was considered absolute or relative, plaintiffs still would face the formidable task of persuading the Court that it must essentially legislate standards for these numbers to insure that the same degree of relative adequacy or inadequacy of benefits is provided to each family. Although the precise terms of many constitutional rights the Court has defined are complex, most can be summarized qualitatively in a few words. 
quate" benefit. Here again, failure to understand existing programs may lead to a proliferation of semi-overlapping ones. ${ }^{245}$

The lack of a functional entitlement also complicates evaluation of the program. If the program has no describable functional goals, how can anyone determine how well it is performing? This presents several problems. First, it is likely to lead to divergent, politically motivated assessments of the program that confuse and frustrate the public. Ultimately, the program's critics may sound more persuasive since its champions' arguments are likely to sound inconsistent: The program is doing well in combating whatever problem it is there to meet, yet the problem persists with such severity that additional resources are needed. To the extent that reasoned arguments become less effective in setting a program's funding level, the program becomes more vulnerable to rent-seeking that diverts its resources and distorts its priorities. In addition, without clear functional goals programs may become subject to drift and eventual capture by provider groups or other interested parties. A program's supporters should be concerned that difficulties in evaluating its management could allow inefficient administration to linger, wasting scarce resources and discrediting social initiatives generally.

In the absence of a functional entitlement, policymakers, analysts, and journalists will tend to compare a program against the way it operated in prior periods. ${ }^{246}$ Unfortunately, absent a functional entitlement, the most convenient way of expressing a program's past performance is its budget. This can be more misleading than edifying, however, if eligible claimants' need for services, or the costs of providing those services, changes significantly. Most obviously, these budgets commonly are compared without allowing for inflation. ${ }^{247}$ Thus, for example, Medicare's and Medicaid's costs often come in for sharp criticism during periods of general medical inflation. ${ }^{248}$ For a nonentitlement health care program to continue to provide comparable care to a similar fraction of eligible claimants over the last few years, therefore, it likely would need to receive annual double-digit increases in nominal funding. Few but the most sophisticated observers will recognize this when hearing comparisons of programs' budgets over time.

245. See supra text accompanying note 236.

246. Here again, responsive and functional entitlements are closely parallel. See supra notes 223-225 and accompanying text.

247. This point has not been lost on House Republicans. When they took over the House after the 1994 elections on a platform of reducing government spending, they directed the Congressional Budget Office (CBO) to produce baselines for discretionary programs without any adjustment for inflation. H.R. Con. Res. 67, 104th Cong., $\$ 311$ (1995). This allowed them to show nominal increases in programs' funding even as those programs' purchasing power eroded.

248. See, e.g., Woodward, supra note 26, at 141 (describing the effect of limiting Medicare's spending growth to the general inflation rate at a time when health care inflation had been running several times higher). 
3. Unconditional Entitlements. - Although no program is a pure unconditional entitlement, as a program becomes more conditional it tends to become more difficult to understand. Thus, a program that provides a readily describable benefit to all those that qualify-a program that is both a responsive and a functional entitlement-may sound most impressive. If, however, its eligibility conditions prevent most of its target population from accessing the benefit, the program may be little more than an elaborate mirage. Here the problem is not with all conditions so much as it is with complex or misleading ones. ${ }^{249}$

Even if a condition is relatively easy to explain, its consequences may not be. For example, the concept of a five-year time limit is easy to grasp, but understanding how many claimants a time limit is likely to affect requires a sophisticated knowledge of program dynamics. Understanding which claimants are likely to be affected, and why, is even harder. ${ }^{250}$ The more conditional a program becomes, the larger the gap is likely to become between the public's perceptions of the program and the reality experienced by claimants seeking to access it. ${ }^{251}$

Because middle-income people will tend to underestimate eligibility conditions' impact on low-income claimants, the public is likely to overestimate what its government is doing for low-income people. This, too, systematically biases debates toward reducing assistance to low-income

249. Programs lacking responsive entitlements are likely to accumulate more complex eligibility conditions as their managers struggle to keep participation within the programs' caps. See supra Part Il.B.1.b.

250. The average middle-income voter's appreciation of eligibility conditions may be further distorted because few have much experience with the pressures confronting lowincome claimants. A middle-income person with good job skills might think that five years is a long time to receive assistance-certainly he or she would not need assistance for that long-without having any real idea of the barriers many claimants can face in securing an alternative source of income. Middle-income people who appear for appointments when called by government agencies may miscalculate the likelihood that low-income people will miss an appointment due to stolen mail, unreliable child care, delayed public transportation, or the difficulty of juggling demands on their time and resources that far outstrip what the claimants have to meet them.

251. Other problems also are likely to ensue. This can be understood from an examination of the three models of administrative adjudication that Professor Mashaw posits for public benefits cases. Mashaw, Bureaucratic Justice, supra note 187, at 23-31. His "professional treatment" model seeks to ensure that the program is faithful to its often paternalistic purposes in providing aid to those in need. Although eligibility conditions often are imposed in pursuit of these paternalistic ends, the accumulation of a large number of conditions can interfere with the program's ability to achieve its core purposes. Id. Professor Mashaw's second, "moral judgment" model seeks to borrow legalistic elements from civil litigation to ensure that claimants can assert their rights effectively. The more complex a set of eligibility conditions are, the more costly it will be for the government to adjudicate claimants' compliance with those requirements in a legalistic way. Id. Finally, his "bureaucratic rationality" model seeks consistent, predictable outcomes that treat similarly situated claimants similarly. The more conditions a program imposes on eligibility, the more subjective judgments will be required and the more the program will be vulnerable to variations among adjudicators' approaches. Id. 
people. ${ }^{252}$ Thus, if one seeks to destroy a program altogether, making it more conditional may be an even more effective strategy than destroying responsive or functional entitlements. ${ }^{253}$

4. The Aggregate Political Effect of Nonentitlement Programs. - Quite apart from the obfuscating effect nonentitlement status has on individual programs, the presence of so many such programs also makes it difficult for the public to make informed judgments about the state of anti-poverty policy generally. ${ }^{254}$ This can affect entitlement programs as well as those lacking responsive or functional guarantees. For example, when considering whether to support an increase in food stamp or SSI benefits, should a voter think of the needs of a recipient who also gets housing subsidies or one who does not?255 Many sensible voters might support an SSI increase for recipients without housing subsidies but see insufficient justification for the increase for those receiving substantial housing aid. Similarly, voters weighing the merits of an SSI or food stamp increase may be uncertain whether to assume that LIHEAP payments largely cover recipients' utility costs or still leave recipients struggling with large bills. Each side of the debate will ask voters to visualize whichever type of claimant is politically convenient. ${ }^{256}$

252. This is true without regard to how large an intervention one favors. If most policymakers and voters believe it is doing more than in fact it is, those that favor a more expansive intervention will feel less urgency to act while those wanting more modest programs may mistakenly believe that the status quo exceeds the level they find tolerable. Thus, the tendency to underestimate eligibility conditions' impact undermines all conscientious advocates of programs across the political spectrum.

253. See supra text accompanying notes 236 and 245.

254. See, e.g., Debra J. Saunders, The System Can Never Do Enough, S.F. Chron., Sept. 25, 1995, at A19 (citing conservative estimates that "the 75 major federal welfare programs make up 5 percent . . . of the gross domestic product"); Robert E. Rector, Heritage Found., Means-Tested Welfare Spending: Past and Future Growth (Mar. 7, 2001), available at http://www.heritage.org/Research/Welfare/Test030701b.cfm (on file with the Columbia Law Review) (making similar assertions by including many programs, such as Head Start, that few would consider "welfare").

255. Not surprisingly, the analyses of conservative and liberal groups differ on this point, with conservatives arguing that enough low-income people receive housing subsidies to make it legitimate to count them in the budget of a typical family while liberals point out that the great majority of low-income people do not receive those subsidies. Compare, e.g., Tanner et al., supra note 188 (including the value of housing and other benefits in drawing conclusion that welfare income is greater than likely income of entry-level worker "in virtually every state"), with Sharon Parrott, Ctr. on Budget \& Policy Priorities, The Cato Institute Report on Welfare Benefits: Do Cato's Numbers Add Up? 1-2 (1996) (excluding such benefits).

256. E.g., 142 Cong. Rec. 18,486 (1996) (statement of Sen. Santorum) (justifying elimination of responsive entitlement to cash assistance by insisting that "guarantee[s]" existed for most family needs and that current system was an over-functional entitlement with " 50 or more programs that are there to take care of every possible need a child in America has"). Senator Santorum asks, "Do we want the Federal Government guaranteeing every aspect of everybody's life?" Id. Compare, e.g., Tanner et al., supra note 188 (suggesting that the generosity of AFDC benefits be assessed based on claimants receiving a wide range of benefits from programs that lack responsive entitlements, 
5. The Impact of Combining Responsive and Functional Entitlements. Comparing the success of entitlement programs with that of nonentitlements suggests the difficulty policymakers and voters have in understanding the latter. In particular, several of the benefit programs that have grown fastest in recent years are those that combine responsive and functional entitlements. ${ }^{257}$ The direct cause of the growth has been increased demand, but the programs have been allowed to meet this demand in large part because their coverage and benefits are so transparent.

One of the fastest-growing major components of Medicaid, for example, is long-term care for the elderly and persons with disabilities. ${ }^{258} \mathrm{Like}$ the rest of Medicaid, it is a responsive entitlement. ${ }^{259}$ Much more clearly than the rest of Medicaid, however, it is also a functional entitlement, designed to cover fully the needs of persons in institutions. ${ }^{260}$ This is largely inevitable since its eligibility rules require beneficiaries to turn over all of their funds, effectively depriving them of any ability to meet other needs on their own. ${ }^{261}$ Because it is widely understood as a functional entitlement, ${ }^{262}$ politicians can expect severe scrutiny if they establish limits on the amount, duration, or scope of services that cause harm

functional entitlements, or both), with Parrott, supra note 255, at 3-6 (arguing that most AFDC recipients get nothing from many of the programs Cato cites and that those who do typically receive much lower benefits than Cato suggests).

257. By contrast, domestic low-income discretionary programs-programs that may or may not offer functional entitlements, but that generally do not operate as responsive entitlements-as a group have fallen steadily behind the funding levels required to keep up with inflation and population growth in recent years. See Richard Kogan, Ctr. on Budget \& Policy Priorities, Left Behind in Good Times and Bad 3-5, 9-12 (2003).

258. See Kaiser Comm'n on Medicaid and the Uninsured, Medicaid: Fiscal Challenges to Coverage 2 (2003), available at http://www.kff.org/medicaid/4112index.cfm (on file with the Columbia Law Review) [hereinafter Kaiser, Fiscal Challenges] (finding that seventy-seven percent of Medicaid growth between 2002 and 2003 was attributable to the elderly and persons with disabilities and that the highest average annual growth rates between 1998 and 2000 were in services used disproportionately by those groups, particularly prescription drugs, home care, and long-term care).

259. 42 U.S.C. $§ 1396 a(a)(10)$ (2000); see also id. $§ 1396$ r(c)(5) (prohibiting nursing homes from interfering with the responsive entitlement to Medicaid).

260. See, e.g., id. $\$ 1396$ r (b) (2) (requiring nursing homes to "provide services and activities to attain or maintain the highest practicable physical, mental, and psychosocial well-being of each resident"); see also, e.g., id. $\$ 1396 \mathrm{r}(\mathrm{b})(1)$ (A) (requiring nursing homes to "care for its residents in such a manner and in such an environment as will promote maintenance or enhancement of the quality of life of each resident"); id. $\$ 1396 \mathrm{r}$ (c) (providing extensive substantive, as well as procedural, rights to residents).

261. Id. $\S 1396 \mathrm{a}(\mathrm{q})$; see also id. $\$ 1396 \mathrm{r}-5$ (d).

262. See, e.g., Steve Bousquet, Lawmakers Scrounge Coins Under Budgetary Cushions, St. Petersburg Times, Oct. 24, 2001, at 5B (describing legislators' extraordinary efforts to avoid cutting nursing home staffs despite state fiscal crisis); Muriel Dobbin, States Score Poorly on Care of Terminally Ill, Fresno Bee, Nov. 19, 2002, at A7 (describing pledges of action from executive and legislative branch leaders in response to a report on poor quality of care). 
to nursing home residents. ${ }^{263}$ With participation caps and significant service limitations politically or legally barred, the federal and state governments can control costs only by tightening eligibility conditions. With the benefit at stake readily describable, and many of those seeking care from the politically potent middle-class, ${ }^{264}$ this approach, too, has limited prospects. ${ }^{265}$

Although other components of Medicaid, such as prescription drugs, are responsive entitlements that also have been growing rapidly, the absence of as sharply defined a functional entitlement ${ }^{266}$ has allowed states more ability to offset increased demand with limits on services as well as tighter eligibility conditions. ${ }^{267}$ In the current state fiscal crisis, services for children have survived far better than those for non-institutionalized adults ${ }^{268}$ primarily because Medicaid's early and periodic screening, diagnostic, and treatment (EPSDT) component provides a much clearer functional entitlement. ${ }^{269}$

Two other fast-growing programs in the decade before PRWORA were the School Breakfast Program and the Child and Adult Care Food Program (CACFP). ${ }^{270}$ They, too, are functional entitlements, defined by

263. See 42 C.F.R. $\$ 440.230$ (b)-(c) (2002) (requiring services to be of sufficient amount, duration and scope to reasonably accomplish their purpose). States do try to save money by keeping provider reimbursements as low as possible. With nursing homes having strong trade associations, the opportunities to save money on reimbursements to homes is limited both politically and legally. See, e.g., Concourse Rehab. \& Nursing Ctr., Inc. v. Whalen, 249 F.3d 136, 139-42 (2d Cir. 2001) (describing public procedure states must follow to set institutional reimbursement rates); Geriatrics, Inc. v. Colo. Dep't of Soc. Servs., 712 P.2d 1035, 1040 (Colo. Ct. App. 1985) (requiring state to reimburse nursing homes for cost of oxygen).

264. See, e.g., Stress Points in the State Budgets, N.Y. Times, Dec. 30, 1990, at 16.

265. See, e.g., Brigit Schulte, Budget Deadlock Forces Shutdown, Austin AmericanStatesman, Dec. 16, 1995, at A1 (quoting a Republican congressional staffer describing Republican proposal to shift some of cost of caring for middle-income nursing home residents from Medicaid to their families as "political suicide").

266. Compare, e.g., Weaver v. Reagen, 886 F.2d 194, 200 (8th Cir. 1989) (requiring coverage of AZT for HIV and AIDS despite lack of FDA approval at that time), and Pinneke v. Preisser, 623 F.2d 546, 549-50 (8th Cir. 1980) (requiring coverage for sex reassignment surgery), with Smith v. Rasmussen, 249 F.3d 755, 761-62 (8th Cir. 2001) (refusing to order state to pay for medically necessary sex reassignment surgery).

267. See generally Donna Cohen Ross \& Laura Cox, Kaiser Comm'n on Medicaid \& the Uninsured, Preserving Recent Progress on Health Coverage for Children and Families: New Tensions Emerge 2-3 (2003) (citing new restrictions on income eligibility and administrative obstacles as reasons for declining participation in public health care programs in some states).

268. Id. at i-iii.

269. Nine states reduced benefits in 2002 , twenty-five states did so in 2003 , and the administrations in twenty states expect to do so in 2004. Kaiser, Fiscal Challenges, supra note 258, at 3. EPSDT's functional entitlement prevents states from applying these cuts to children. 42 U.S.C. $\$ 1396 d(r)(5)$ (2000) (requiring states to cover necessary services for children whether or not those services are otherwise part of the state's Medicaid plan).

270. In federal fiscal year 1986, the School Breakfast Program cost $\$ 406$ million; the Child Care Food Program, \$483 million. Database Monitoring Branch, U.S. Dep't of Agric., Program lnformation Report: September 1987 tbls.10 \& 15 (1987) [hereinafter 
the meals they are required to provide. ${ }^{271}$ They are responsive entitlements from the perspective of eligible schools, centers, and homes, and where providers participate, a responsive entitlement for eligible children as well. Political and demographic changes have prompted more schools to offer breakfasts; demographic changes also have led to a dramatic increase in the number of participating child care providers. These programs' entitlement structures have made them easy for the public to understand and, because what they are doing is popular, they have become politically strong without the focused attention of moneyed provider groups. ${ }^{272}$ PRWORA did reduce CACFP significantly, but only because the legislation's sponsors found a way to make eligibility more conditional: means-testing eligibility in family day care homes. This change was politically viable because its effects were somewhat obscure. ${ }^{273}$

The National School Lunch Program has not grown nearly as fast as the School Breakfast Program or CACFP, ${ }^{274}$ primarily because the vast majority of eligible schools and children enrolled many years ago. The strength of its combined responsive and functional entitlements became apparent in the 1995-1996 welfare debate when the otherwise dominant House Republicans were badly embarrassed and forced to retreat from proposals to cut funding for school meals. ${ }^{275}$

To be sure, all of these programs serve relatively appealing constituencies. Yet other programs providing important services to the same con-

1987 Keydatal. By fiscal year 1997 , those totals had increased to $\$ 1.211$ billion and $\$ 1.561$ billion, respectively (with a tiny part of the latter increase attributable to an expansion to cover adult care centers). Database Monitoring Branch, U.S. Dep't of Agric., Program Information Report: September 1997 tbl.29b (1997) [hereinafter 1997 Keydatal. Even after accounting for the decade's $35 \%$ total food inflation, this represents increases of $120 \%$ in breakfast and $139 \%$ in child care food.

271. 42 U.S.C. $\$ 1766(\mathrm{~g})(1)(\mathrm{A})$.

272. Although the teachers' unions and other education trade associations take a passing interest in the school meal programs, their primary focus is decidedly on programs and policies affecting classroom instruction. See Nat'l Education Ass'n, NEA on the Issues, at http://www.nea.org/topics (last visited Feb. 22, 2004) (on file with the Columbia Law Review) (listing twenty-one areas of interest to NEA, none of which involve school meals even though legislation making significant changes to those programs is currently before Congress); Am. Fed'n of Teachers, AFT on the Issues, at http://www.aft.org/issues/ index.html (last visited Feb. 22, 2004) (on file with the Columbia Law Review) (similarly listing fifteen issue areas, none of wbich involve school meals).

273. Personal Responsibility and Work Opportunity Reconciliation Act of 1996 (PRWORA), Pub. L. No. 104-193, § 708, 110 Stat. 2105, 2293-94. The CACFP means test's direct effect was to reduce the payments many homes qualified to receive. Its indirect effect, however, may have been more significant: increasing paperwork burdens to the point that some homes completely left the program, rendering all children enrolled at those homes unable to participate in CACFP.

274. From 1986 to 1996, spending on the National School Lunch Program increased from $\$ 3.55$ billion, 1987 Keydata, supra note 270 , tbl.6, to $\$ 5.35$ billion, 1997 Keydata, supra note 270 , tbl.6, a $12 \%$ increase after allowing for inflation.

275. See Robert Pear, G.O.P. Finds It Difficult to Deflect Attacks on the School Lunch Proposals, N.Y. Times, Apr. 9, 1995, at 18; see also infra Part III.C.2. 
stituencies faired far worse. ${ }^{276}$ More generally, it likely is precisely because these programs are so politically appealing that they have been able to establish themselves as both functional and responsive entitlements.

\section{Political Distortions Resulting from Confusion About Entitlements}

The difficulty of conceptualizing nonentitlement programs clearly has caused the political process to adapt in several ways. Most obviously, as noted above, politicians, analysts, and journalists assume the existence of responsive and functional entitlements even when that is clearly not the case. In two other important respects, too, these distortions have further obstructed informed debate about the scope and terms of public benefits programs.

I. Manipulation of Varying Definitions of "Entitlement." - As the passages at the opening of this piece suggest, attitudes toward and willingness to discuss entitlements vary considerably across the political spectrum. Opposing political groups also seek to exploit confusion about the definition of "entitlement." A program's detractors attack an unpopular type of entitlement to build support for policies curtailing other types; its champions similarly tout the importance of more popular types of entitlements to parry efforts to curtail those with less public sympathy.

Supposed subjective and unconditional entitlements are favorite targets of criticism. ${ }^{277}$ Programs' champions rarely offer a direct defense of either, presumably reluctant to portray their beneficiaries as taking public largesse for granted or having qualified for that largesse under lax standards. Instead, programs' advocates prefer to argue that programs are more conditional than is commonly understood. Alternatively, programs' advocates sometimes concede proposals to make benefits more conditional but argue that these additional conditions transform the benefit into a kind of social contract with reciprocal obligations that justifies a responsive entitlement. ${ }^{278}$

276. For example, Congress refused to prevent a deep reduction in SCHIP funding in $200 \mathrm{I}$, even as deterioration in states' budgets was making that funding vital. Congress and the Bush Administration delayed almost a year before extending the availability of unused SCHIP funds scheduled to expire. See Pub. L. No. I08-74, I I7 Stat. 892 (2003).

277. Many leading Republicans argued that eliminating the AFDC entitlement was crucial to the success of welfare reform, but it is not always clear which type of entitlement they had in mind. Reps. Johnson, Archer, Shaw, and Hastert, in the passage quoted supra text accompanying note 3 , appeared to be thinking primarily of subjective and unconditional entitlements, yet it is far from clear that AFDC was either of those.

278. See, e.g., I4I Cong. Rec. 8499 (I995) (statement of Rep. Clement) ("In short, we guarantee recipients that if they will go to work we will provide the money and take all the necessary steps to ensure that recipients have a real opportunity to become selfsufficient."). Similarly, members of Congress from farm states justified the 1995 Freedom to Farm Act as a social compact in which farmers would receive increased subsidies for a few years in exchange for moving to a more market-driven production system. See 142 Cong. Rec. 7082-83 (I996) (statement of Rep. Roberts); id. at 7083-84 (statement of Rep. Buyer). A system of mutual obligations-conditional eligibility and a responsive entitlement for those that meet those conditions-may be contrasted with a barter system 
Many critics of programs, on the other hand, have proven reluctant to attack responsive entitlements directly. ${ }^{279}$ Conversely, programs' advocates, who have been unwilling to defend subjective, unconditional, or even positive entitlements, are sometimes a bit more vocal on the need for responsive entitlements. ${ }^{280}$ With the distinctions among the various types of entitlements so poorly understood, it is possible that the success of these arguments in the 1995-1996 welfare debates might have preserved positive entitlements as well. ${ }^{281}$

2. Obscuring Policy Through Devolution. - Establishing a program without a responsive or functional entitlement tends to change the nature of the choices that must be made to ration benefits. Responsive and functional entitlements can be constrained with relatively broad conditions that are amenable to public debate and definitive legislation. By

in which claimants are not assured that their compliance with eligibility conditions will indeed result in an award of benefits. See supra notes 58-60 and accompanying text.

279. Indeed, even as they were arguing for passage of PRWORA, which ended the responsive entitlement to AFDC without establishing any alternative responsive entitlement in its place, many conservatives incorrectly asserted that they were continuing to assure benefits for all those that qualified. For example, Sen. Santorum promised recipients "education and training that is meaningful" and declared that "if you cannot find a job in the private sector, if you cannot get a job on your own, the State will assist you getting that job. If you cannot find a private-sector job, the State will assist you in getting a public-sector job." 142 Cong. Rec. 18,486 (1996).

280. See, e.g., 142 Cong. Rec. 18,488 (1996) (statement of Sen. Daschle) (stating, "I have heard the discussion of a Iist of other Federal programs that may be provided. But, Mr. President, tbe emphasis is on 'may'" and arguing that "[ilf they do not have the resources, if we do not have the safety net, if they do not have the opportunities to access those programs, then, Mr. President, they are meaningless").

281. Indeed, the opposing camps' reluctance to challenge one another directly over any one form of entitlement suggests that their bottom lines may be closer than is commonly realized. In full control of Congress and facing a president loath to veto a welfare bill a few months before facing the voters, Republicans had no need to compromise in 1996. Had negotiations taken place, however, one can imagine a compromise in which a responsive entitlement to cash assistance remained but became far more conditional and was shorn of whatever features could plausibly be said to engender subjective entitlement. Also, the 1996 welfare law eliminated the entitlement to child care for AFDC recipients complying with JOBS work requirements and for AFDC recipients in their first year after having worked their way off of AFDC. Yet with some prominent Republicans emphasizing that the problematic entitlement was to cash assistance, one can imagine these child care entitlements being preserved. Had that been done, considerably more child care assistance to working families likely would be available today notwithstanding the large nominal increases in funding the child care and development block grant received in 1996. See generally Sharon Parrott \& Nina Wu, Ctr. on Budget \& Policy Priorities, States Are Cutting TANF and Child Care Programs: Supports for LowIncome Working Families and Welfare-to-Work Programs Are Particularly Hard Hit 2, 19-28 (June 3, 2003), available at http://www.cbpp.org/6-3-03tanf.pdf (on file with the Columbia Law Review) (describing cutbacks that have left child care subsidies virtually unavailable for families not receiving cash assistance in about twenty states). Prior to PRWORA, child care subsidies for cash assistance recipients were a responsive entitlement, with two additional funds available for other low-wage workers. 42 U.S.C. $\$ \S 602(\mathrm{~g})(1)$, (i), 603(a) (1994) (repealed 1996); id. \$§ 9858-9858q (1994) (amended 1996). 
contrast, keeping a program within a spending or participation cap is likely to require an ongoing series of adjustments to eligibility rules and benefit levels that are too nuanced, and too numerous, for effective public debate. These adjustments also may need to be made more rapidly than the legislative process, or even administrative rulemaking, can accommodate.

Thus, eschewing entitlement structures tends to make rationing decisions less visible and hence less subject to democratic review and revision. This is true when the federal government pays state governments to administer a benefit program without a responsive entitlement under federal law. 1t is equally true when state officials hand their local counterparts a program for which available funding is insufficient to assure a responsive entitlement. 1t also is true when high officials in a bureaucracy ask their subordinates to do more than available resources will allow. ${ }^{282}$

Not surprisingly, then, a study of eleven major block grants over the past two decades found that their funding declined by an average of twenty percent after adjusting for inflation (but without adjusting for other changes in need) ${ }^{283}$ Excluding the Child Care and Development Block Grant, which received a large one-time increase in 1996 to help it cope with the demands of welfare recipients entering the workforce or work programs, real funding for the remaining block grants declined by more than a quarter over this period. ${ }^{284}$ This erosion is all the more remarkable because the direct recipients of these block grants-chiefly governors, county commissioners, and mayors-have far more political capacity to fight for higher funding than do low-income beneficiaries of entitlements. 285

282. When PRWORA replaced AFDC's responsive entitlement with the TANF block grant, it gave states powerful fiscal incentives to reduce spending on benefits. Since states generally concluded that departing from a de facto responsive entitlement would be an administrative nightmare and a potential political embarrassment, those seeking to reduce their expenditures on cash assistance needed to make benefits either less functional or more conditional. Most of the welfare law's critics predicted the former, escalating reductions in benefit levels characterized as a "race to the bottom." See, e.g., Edelman, supra note 11 , at 146-47 (explaining that rather than cutting benefits, states achieved reductions in welfare roles through "sanctions and terminations, combined with rejection of new applicants"). In practice, most states found the latter route easier and more productive of the declines in caseloads that had become tbe de facto measure of states' success. See, e.g., id. (pointing out that in some states, it was infeasible to cut benefits below already minimal levels).

283. Matthew Broaddus, Ctr. on Budget \& Policy Priorities, Federal Funding for Block Grants Erodes over Time 3 (2003).

284. ld. at 1,3 .

285. Even if some of these officials do not feel any particular passion for helping lowincome people, these funds could reduce demand for spending state funds on this population. This would free up state revenues to address other priorities. 


\section{Recent Political Struggles over Entitlements: Means-Tested Public Benefit Programs}

The principles developed above are much more than abstractions. They increasingly have shaped the outcome of struggles over public benefit policy in recent years. In particular, debates about the proper role of entitlements have increasingly driven policy in means-tested programs. More broadly, the absence of entitlements has allowed both program advocates and opponents to pursue covert political agendas. Some liberals have sought to disguise the extent of the expansions they seek in the public sector by starting with small nonentitlements serving a small fraction of the beneficiaries and functions of the programs that were their ultimate ends. Conversely, some conservatives have made a fundamental principle out of reducing entitlement programs and the taxes-in a sense, negative entitlements-that support them. ${ }^{286}$ This section identifies the impact of entitlement status on public benefit programs' political vulnerability, considers the rhetorical problems that both supporters and opponents face in debating entitlement and nonentitlement programs, and explores the sometimes paradoxical behavior of many political activists toward the concept of entitlement. Although the principles discussed here apply to a wide range of programs, this section focuses on the debates over means-tested programs over the past few decades, following the common if imprecise convention of identifying critics of those programs as conservatives ${ }^{287}$ and those programs' defenders as Iiberals. ${ }^{288}$

1. The Traditional Values-Based Model of Public Benefits Debate. - In this country, battles over public welfare law often have been fought in moralistic terms. Opponents of means-tested benefits have sought to impose eligibility restrictions based on the supposed moral failings of low-income

286. See, e.g., John Maggs, Grover at the Gate, 35 Nat'l J. 3100,3101 (2003) (describing tax-cutting as a central theme of the conservative platform in Washington); Americans for Tax Reform, Taxpayer Protection Pledge, at http://www.atr.org/ nationalpledge/index.html (last visited Jan. 30, 2004) (on file with the Columbia Law Review) (pledging to oppose any raises in federal taxation levels).

287. Some conservatives, of course, have sought significant expansions of social welfare programs. See, e.g., 148 Cong. Rec. S610 (daily ed. Feb. 12, 2002) (statement of Sen. McConnell) (proposing across-the-board increase in food stamps for families with children); id. at 498 (daily ed. Feb. 7, 2002) (text of amendment increasing food stamp benefits co-sponsored by conservative Republican Sens. Brownback, Ensign, Fitzgerald, Grassley, Hagel, and Lugar, as well as some liberal Democrats); id. at \$419 (daily ed. Feb. 6, 2002) (statement of Sen. Durbin) (conservative Republican Sens. Domenici, Lugar, and Smith joining with liberal Democratic senators to sponsor amendment to provide food stamps to legal immigrants); Vincent J. Burke \& Vee Burke, Nixon's Good Deed 188-204 (1974) (describing President Nixon's initiative to create Supplemental Security lncome (SSI) program for elderly and persons with disabilities living in poverty).

288. Partisan identification is more difficult. A great many Democrats have supported sharp reductions to means-tested programs, particularly in the mid-1990s, while a number of Republicans opposed or sought to moderate many of these cuts. 
people. ${ }^{289}$ Champions of these programs have written exposés of the difficult conditions faced by the poor ${ }^{290}$ or counter-attacked programs' critics for their supposed insensitivity to that plight. ${ }^{291}$ These time-honored strategies for gaining political leverage will no doubt continue.

These strategies, by themselves, are unlikely to produce any clear, lasting victor. Consistently over time, the American public holds conflicted feelings about low-income people and public efforts to aid them. lt feels compassion for low-income people in distress but is suspicious of their morals. ${ }^{292}$ It sees relief of suffering as an appropriate public function in such a wealthy country but feels cheated when anti-poverty programs' failings are exposed. ${ }^{293}$ Left on their own, these moral arguments are likely to lead to cyclical changes in public policy, as a round of sympathetic stories about struggling families generates a groundswell for expansions of social initiatives, only to be followed by a round of stories about fraud or bureaucratic inefficiency that sends the pendulum swinging back the other way. The public is likely to have at least a crude sense of which side has been getting its way most recently and may become receptive to its competition's claims that things have gone "too far."

The continuation of this pattern depends, however, on some degree of transparency in the programs themselves. Programs with responsive and functional entitlements, and with relatively intelligible eligibility conditions, provide a fair amount of transparency. Capped programs with

289. See, e.g., Herbert J. Gans, The War Against the Poor 14-47 (1995) (tracing history of stigmatizing labels for low-income people); Graham, supra note 207, at 59-63 (describing the "man in the house" rule and other efforts to regulate the sexual and other morality of women seeking AFDC); Michael B. Katz, 1n the Shadow of the Poorhouse 276-80, 286-87 (1986) [hereinafter Katz, Poorhouse] (finding that critiques of moral failings of "underclass" provided the foundation for President Reagan's programmatic changes in public benefit programs in early 1980s); Katz, Citizenship, supra note 1, at 196-97 (describing "moral hazard" theory for curtailing social insurance and means-tested benefits); David Zucchino, Myth of the Welfare Queen 64-65 (1997) (quoting Ronald Reagan's attacks on welfare recipients' honesty in his second presidential campaign).

290. See, e.g., Michael Harrington, The Other America 19-38 (1962) (noting conditions faced by low-income people generally); Peter H. Rossi, Down and Out in America 1-8 (1989) (homeless); John E. Schwarz \& Thomas J. Volgy, The Forgotten Americans 16-31 (1992) (low-income workers).

291. See, e.g., David Dahl, In Washington, They Pick Words Carefully, St. Petersburg Times, Feb. 6, 1995, at 1A (quoting Republican pollster as saying that Republicans' proposals for orphanages made them Iook mean); Howard Kurtz, Spin Cycles: A Guide to Media Behavior in the Age of Newt, Wash. Post, Feb. 26, 1995, at 8, 11 (Magazine) ("Many articles seized upon Gingrich's welfare proposals, painting the Republicans as the party of orphanages."); Republicans Slow to Adopt Gingrich Orphanage ldea, Omaha WorldHerald, Dec. 8, 1994, at 13 (same).

292. See, e.g., Katz, Poorhouse, supra note 289, at 276-80 (tracing the history of society's moral judgments about low-income people in the U.S.); David J. Rothman, The Discovery of the Asylum 161-95 (1971) (describing institutionalization movement of early nineteenth century as effort to rectify morals of poor).

293. Weaver, supra note 174, at 172-77 (discussing contrast between positive public sentiment toward programs for the poor and general public dissatisfaction with existing welfare programs). 
arbitrary funding levels, distributing benefits in arbitrary amounts to an arbitrary fraction of an eligible population defined by intricate eligibility conditions, on the other hand, can be transformed without much public comprehension. This has created opportunities for single-minded factions on both ends of the political spectrum. Supporters of a program can increase its funding many times over while continuing to claimtruthfully - that unmet need remains. Opponents of a program, in turn, can devastate its coverage, benefit levels, and eligibility requirements without the public realization that is needed to send the political pendulum swinging in the other direction.

In these circumstances, a more permanent shift in the generosity of these programs becomes possible if the side of the debate holding the levers of power is willing to apply them single-mindedly. During the 1960 s and 1970s, several programs grew from modest beginnings-lacking responsive entitlements, functional entitlements, or both-to become major entitlements. ${ }^{294}$ Over time, however, the advantage is more likely to accrue to opponents of these programs: Removing money from a program does not require the same kinds of hard choices elsewhere in the budget that adding funds does. Even if advocates of greater social spending would like to pump up the funding of an array of nonentitlement programs, they must find offsetting cuts somewhere else in the budget, run the political gauntlet to increase taxes, or be held accountable for deficit spending. Whittling away at programs' funding presents no such dilemma and may even allow the programs' foes to curry political favor by redirecting the proceeds to other popular causes. ${ }^{295}$

294. For example, the food stamp program began in the early 1960 s as a pilot program. Pub. L. No. 86-341, § 11, 73 Stat. 606, 608 (1959) (authorizing food stamp pilot program). Under President Nixon's guidance, Congress made it available nationally and then added a functional entitlement to a nutritionally adequate diet in the late $1960 \mathrm{~s}$ and early 1970s. Pub. L. No. 91-671, 84 Stat. 2048, 2048 (1971). Similarly, the Special Supplemental Nutrition Program for Women, lnfants, and Children (WIC) grew from a tiny pilot to a de facto responsive entitlement between the early $1970 \mathrm{~s}$ and the late $1990 \mathrm{~s}$. Compare Pub. L. No. 92-433, § 9, 86 Stat. 724, 729 (1972) (authorizing two-year WIC pilot program at $\$ 20$ million per year), with, e.g., Pub. L. No. 107-76, tit. IV, 115 Stat. 704, 726 (2001) (appropriating over $\$ 4.3$ billion for WIC); see also H. Conf. Rep. No. 107-275, at 78 (2001), reprinted at 2001 U.S.C.C.A.N. 757, 780 (expressing the expectation that the funds appropriated would be sufficient to meet all demands for WIC benefits and still have enough left over to fund some additional activities). Medicaid grew from a very limited indigent health care subsidy, Pub. L. 89-97, 79 Stat. 343 (1965) (establishing Medicaid); Walter I. Trattner, From Poor Law to Welfare State 327-29 (5th ed. 1994) (tracing evolution of Medicaid), to a responsive entitlement with a fairly broad functional entitlement over the course of the 1960s and early 1970s.

295. Some empirical support for this hypothesis can be found by comparing changes in funding for low-income domestic discretionary programs in 1993-1994, the first two years in more than a decade when Democrats controlled the White House and both houses of Congress, and in 1995-1996, the first two years of Republican control of both houses of Congress in a generation. Despite having to deal with a Democratic president, Republicans cut discretionary funding for low-income programs far more than Democrats had added to it. Robert Greenstein et al., Ctr. on Budget \& Policy Priorities, Bearing Most 
This would seem to suggest a set of covert political strategies that programs' single-minded supporters and opponents can use to manipulate policy. Because the group with the strongest control of the levers of government generally benefits from public misunderstandings about the scope of nonentitlement programs, ${ }^{296}$ conservatives seeking to abolish or radically shrink these programs today have an apparent interest eliminating responsive and functional entitlements in existing programs and in taking those programs still farther away from the mythical "unconditional entitlement." This strategy, of course, does not make sense for all conservatives. Those who favor more modest investments in social programs, but who want whatever society does spend to be spent effectively, should, and often do, ${ }^{297}$ support entitlement structures to avoid the inefficiencies of nonentitlement structures described in Part II. ${ }^{298}$ And, most simply, those favoring open debate on these issues should favor the more intelligible entitlement structures.

In the current environment, with means-tested programs' supporters relatively marginalized politically, their answer is even clearer. The transparency of entitlement programs generally helps the programs' political efforts to secure more resources while the greater efficiency of the entitlement structure allows those programs to spend more of whatever resources they have on benefits rather than on administering rationing systems. Advocates of extensive government intervention to address a particular set of problems thus should focus their efforts on defending, simplifying, and expanding entitlement programs that address those problems. Conversely, they generally should avoid being distracted by capped programs and those with ill-defined benefits and eligibility conditions. ${ }^{299}$

Those given to covert machinations may, in eras when liberals' political position is stronger, feel tempted to avoid debate over the extent of their desired interventions by starting a small nonentitlement program and trying to grow its funding incrementally over time. Apart from the questionable legitimacy of such a secretive approach, it also dooms the program to the inefficiencies of a nonentitlement program discussed above. ${ }^{300}$

of the Burden: How Deficit Reduction During the 104th Congress Concentrated on Programs for the Poor 8-10 (1996).

296. See supra Part 111.A.

297. See, e.g., Kondratas, supra note 6 , at 6 (arguing for effective programs to meat articulated goals of welfare reform).

298. See supra Part 11.B.

299. The likelihood that this multiplicity of programs will achieve few visible results apart from creating bureaucracies that serve as lightening rods for criticism is another reason for liberals to avoid being distracted by numerous small nonentitlement programs. See supra Part III.B.4.

300. See supra Part II. 1t also assumes that liberals will control government, and have sufficient available funds, for long enough to build up a meaningful and defensible program. Recent history suggests that this is a perilous assumption. 
2. Attacks on Entitlement Programs. - In practice, despite the inefficiencies of an anti-entitlement tack, it has become an important theme of many critics of social spending, particularly an influential faction within the Republican Party. In the social welfare area, the increasing focus of some conservatives on the destruction of the entitlement structure of programs over the past two decades may be in part a result of their disappointment with the results of the "Reagan revolution" of 1981-1982. President Reagan leveraged his enormous popularity to push several packages of specific reductions in low-income programs into law. ${ }^{301} \mathrm{Al}-$ though this effort produced dramatic reductions in these programs, ${ }^{302}$ it also produced a broad perception that the federal government had turned its back on low-income people. ${ }^{303}$ This made the public receptive to significant increases in benefits for low-income people over the next dozen years. ${ }^{304}$

One possible conclusion that conservatives could have drawn from this experience would have been that President Reagan tried to do too much, too rapidly, and in so doing provoked a strong reverse swing of the political pendulum. This could lead conservatives to pursue a more moderate course that could be sustained over the long term. Some clearly did. $^{305}$ Others, however, departed from the relative transparency of the Reagan assault on means-tested programs.

As a result, efforts to reduce means-tested programs since the early Reagan years increasingly have shifted to a two-step strategy. ${ }^{306}$ First, a

301. Joe \& Rogers, supra note 89 , at 49-57; Katz, Poorhouse, supra note 289, at 285-89 (describing cuts enacted in social security, income-maintenance, and related programs induced by the Reagan administration).

302. Katz, Poorhouse, supra note 289, at 285-89 (noting that under the Reagan reductions, 408,000 people lost AFDC eligibility and 299,000 lost AFDC benefits by 1983).

303. See, e.g., Study Cited as Sign of Health Peril to Children of Poor in U.S., N.Y. Times, Apr. 7, 1983, at B15 (quoting Republican Sen. Danforth as saying " $[w]$ e do have an obligation to make sure these people stay alive and have an adequate diet" and expressing the hope that funding for food programs would be increased).

304. Thus, even after PRWORA's even more sweeping reductions in low-income programs, the Congressional Budget Office (CBO) estimated that $\$ 46.1$ billion more in mandatory means-tested benefits would be distributed to low-income people who do not receive cash assistance in 1999 than would have been provided had 1984 rules been applied instead. Cong. Budget Office, Policy Changes Affecting Mandatory Spending for Low-Income Families Not Receiving Cash Welfare 2 tbl.1 (1998), available at http:// www.cbo.gov/showdoc.cfm?index $=849$ (on file with the Columbia Law Review). The increase was primarily in the EITC and Medicaid/SCHIP programs. See id. PRWORA had offset sizeable food stamp increases in 1987, 1988, and 1993. See id. at 15-18 (comparing food stamp eligibility rules in 1984 and 1999).

305. See, e.g., S. 2560, 100th Cong. (1988) (hunger relief legislation co-sponsored by seventeen Republican senators from across the party's ideological spectrum that moderated some of the Reagan food stamp cuts).

306. In fact, both Presidents Nixon and Reagan presaged this strategy by converting a range of categorical programs, some of which provided functional entitlements, into "general revenue sharing" or block grants. See David A. Stockman, The Triumph of Politics 215-21 (1986) (giving an account of the days leading up to passage of President Reagan's 1981 budget-cutting legislation). Once the functions of these programs became 
program is stripped of one or more of its entitlement features, generally without reducing its funding significantly. ${ }^{307}$ With no specific "cuts" to criticize, the program's defenders have difficulty persuading the media and the general public that anything significant is at stake. Second, with the program no longer operating as an entitlement, it can be reduced in relative invisibility or simply allowed to erode under the effects of inflation. ${ }^{308}$

Two major vehicles for destroying functional and responsive entitlements in the social welfare area have been waivers and block grants. Waivers are dispensations federal officials grant to a state government to deviate from the terms of applicable statutes or regulations in its operation of a federally-funded program. The 1995-1996 welfare reform debate was presaged by widespread waivers of many of the most prominent features of AFDC in the late 1980s and early 1990s. ${ }^{309}$ These waivers focused primarily on making the program more conditional; at the margins, some also eroded its responsive entitlement. PRWORA vastly expanded waiver authority in the food stamp program ${ }^{310}$ and created a new waiver-like device, innocuously named the "simplified food stamp program," that allows states to further erode the functional, although not responsive, entitlement of the program. ${ }^{311}$ President Bush's Health In-

blurred, funding for the block grants declined sharply. By the time President Reagan took office, the purposes of general revenue sharing and other Nixon-era block grants had been sufficiently forgotten that he could shut the programs down completely. See id. at 143 (noting the shutting down of Nixon-era block grant programs).

307. Although the main thrust of efforts to eliminate entitlements has been legislative, a few key court decisions have narrowed responsive entitlements, see, e.g., Frazar v. Gilbert, 300 F.3d 530, 544-45 (5th Cir. 2002) (finding that federal regulations acknowledging that states will miss some eligible children in their Early and Periodic Screening, Diagnosis and Treatment (EPSDT) programs preclude standing for all children denied service because none can show that she might not be one of those permissibly left out), and particularly functional ones. See, e.g., Suter v. Artist M., 503 U.S. 347, 363 (1992) (finding no enforceable functional entitlement in child welfare services statute); Pennhurst State Sch. \& Hosp. v. Halderman, 451 U.S. 1, 24-27 (1981) (finding the standards in several laws authorizing programs for persons with mental disabilities too vague to be judicially enforceable).

308. These two strategies can be seen together within a single page the budget President Bush proposed in February 2004. First, he proposes to eliminate the functional entitlement to the Section 8 housing voucher program in favor of giving broad flexibility to local governments. 2005 Budget, supra note 4 , at 185 . Then he criticizes the Community Development Block Grant (CDBG) program-the result of earlier legislation replacing functional entitlements-because local governments have exercised their broad discretion unwisely. Id. at 185-87; see also id. at 219 (proposing to eliminate the State Criminal Alien Assistance Program block grant because states' varied spending choices prevents meaningful analysis of the program's results).

309. See Katz, Citizenship, supra note 1, at 90-101 (recounting various ways states used waivers to modify entitlement structures).

310. 7 U.S.C. $\$ 2026$ (b) (2000).

311. Id. $\S 2035$. 
surance Flexibility and Accountability (HIFA) ${ }^{312}$ and Pharmacy Plus ${ }^{313}$ waiver programs in Medicaid offer to release states from Medicaid's functional entitlement in exchange for states' accepting caps on future funding that are likely to force states to exercise that authority. HIFA also allows states to cap participation for some beneficiaries, making part of Medicaid operate without a responsive entitlement for the first time. ${ }^{314}$ More grandiosely, President Bush and the House have proposed a "superwaiver" as part of the TANF reauthorization that would allow HHS to grant virtually standardless waivers of the rules of a wide range of programs, including food stamps and Section 8 housing assistance. ${ }^{315}$

For single-minded opponents of entitlement programs, block grants have several political advantages over waivers: They affect more states at once, they implicate the federal government less explicitly in any resulting departures from responsive or functional entitlements, and they tend to be politically irrevocable. ${ }^{316}$ Presidents Nixon and Reagan turned to block-granting, for these political advantages, although almost none of the programs they swept up were responsive entitlements, and most were

312. See 2004 Budget, supra note 118, at 126 (explaining how the budget's optional allotment for Medicaid, based on the HIPA initiative, would change current funding); Cindy Mann, Kaiser Comm'n on Medicaid and the Uninsured, The New Medicaid and CHIP Waiver Initiatives 22 (2002), available at http://www.kff.org/medicaid/4028index.cfm (on file with the Columbia Law Review) (noting that each state under a HIFA waiver will be subject to a cap on federal expenditures).

313. See 2004 Budget, supra note 118, at 129-30 (describing Pharmacy Plus waivers and stating that several had been approved and more are pending); Jocelyn Guyer, Kaiser Comm'n on Medicaid and the Uninsured, The Financing of Pharmacy Plus Waivers: Trade Offs Between Expanding Rx Coverage and Global Caps in Medicaid 1 (2003), available at http://www.kff.org/medicaid/4114index.cfm (on file with the Columbia Law Review) (noting that Pharmacy Plus waivers require states to accept a cap on federal Medicaid funding).

314. See Kaiser Comm'n on Medicaid \& the Uninsured, Section 1115 Waivers at a Glance: Summary of Recent Medicaid and SCHIP Waiver Activity 6-7 (2003), available at http://www.kff.org/medicaid/4102-index.cfm (on file with the Columbia Law Review) (noting that waivers allow states to freeze or cap enrollment and may not provide coverage to all those in the eligibility range).

315. H.R. 4, 108th Cong. $\$ 601$ (2003); Executive Office of the President, Working Toward Independence 34-35 (2002), available at http://www.whitehouse.gov/news/ releases/2002/02/welfare-reform-annoucement-book.html (on file with the Columbia Law Review) (stating that states may establish program rules subject only to "minimal Federal requirements").

316. When shifting programs to the state or local level, block grants also may empower officials less sympathetic to income support programs. See Stuart Butler \& Anna Kondratas, Out of the Poverty Trap: A Conservative Strategy for Welfare Reform 82-90 (1987) (stating that states are "less inclined to support income transfer programs" due to concern that richer residents will leave for a nearby jurisdiction); Sheryll D. Cashin, Federalism, Welfare Reform, and the Minority Poor: Accounting for the Tyranny of State Majorities, 99 Colum. L. Rev. 552, 582-83 (1999) (arguing that "the state level [of governmentl provides a worse environment than the national arena for deciding fundamental questions about redistribution [and welfare policy]"). 
not functional entitlements, either. ${ }^{317}$ ln addition to the TANF and child care block grants that ultimately passed in PRWORA, Republicans at one time or another during the 1995-1996 debate proposed to block grant part or all of Medicaid, food stamps, SS1, child nutrition programs, and child welfare services. President Bush recently proposed creating an optional Medicaid block grant for states that would provide more money in the near-term to help them deal with the current fiscal crisis in exchange for capping federal funding in the long-term at a level estimated to fall below what would be spent under existing law. ${ }^{318}$ Similarly, his proposal to block grant the Section 8 housing assistance program would eliminate the standards that make it a functional entitlement. ${ }^{319}$ The TANF reauthorization bills the House passed in 2002 and 2003 both would allow a number of states to convert the food stamp program to a block grant. ${ }^{320}$

In addition to program-specific initiatives, conservatives also have explored devices for eliminating functional or responsive entitlements en masse. The Balanced Budget and Emergency Deficit Control Act of $1985^{321}$ required deep across-the-board budget cuts in most government programs in the event that Congress failed to achieve specified deficit reduction targets. These reductions likely would have the effect of destroying either a functional entitlement or a responsive entitlement in a program that had both. The Iegislation, however, exempted many important low-income responsive entitlements from these sequestrations. ${ }^{322}$ ln practice, Congress allowed only one fairly small sequestration ever to occur under the Act. Subsequent "pay-as-you-go" requirements ${ }^{323}$ did not similarly exempt many low-income programs, making them vulnerable to predation by powerful interest groups seeking to finance tax cuts or increases in other mandatory programs and forcing advocates of program

317. See, e.g., Katz, Citizenship, supra note 1, at 70 ("The [Reagan Administration's] 1981 budget legislation began to transfer responsibility for child care to the states by bundling funds, which had been cut by 20 percent, into block grants and eliminating requirements for state matching funds."); see also supra note 306.

318. See Robin Toner \& Robert Pear, Bush Proposes Major Changes in Health Plans: Critics See Less Security and Fewer Benefits, N.Y. Times, Feb. 24, 2003, at Al (discussing Bush Administration proposals for transforming Medicare and Medicaid).

319. Barbara Sard \& Will Fischer, Ctr. on Budget \& Policy Priorities, Housing Voucher Block Grant Bills Would Jeopardize an Effective Program and Likely Lead to Cuts in Assistance for Low-Income Families 1, 17 (2003), available at http://www.cbpp.org/514-03hous.pdf (on file with the Columbia Law Review) (stating that block grant proposal would terminate link between voucher funding and housing costs and withdraw commitment to consistent federal support of existing vouchers).

320. H.R. 4, 108th Cong. $\$ 602$ (2003).

321. Gramm-Rudman-Hollings Act, Pub. L. No. 99-177, 99 Stat. 1037, 1038 (1985) (codified as amended at 2 U.S.C. $\$ \S 900-922(2000)$ )).

322. 2 U.S.C. $\$ 905(\mathrm{~h})$.

323. Id. $\S 902$. 
expansions to challenge those same interest groups. ${ }^{324}$ Democratic conservatives persuaded President Clinton to establish a system of entitlement spending goals in 1993 as the price of their votes for his budget legislation. ${ }^{325}$ More broadly, by cutting taxes and increasing spending on the military, agricultural subsidies, and highways, the Bush Administration and Congress are creating such large deficits that tougher devices for imposing across-the-board spending cuts are likely to become politically acceptable. Although the specified savings could be achieved through detailed modifications to programs' eligibility rules and benefit levels, the fastest approach-and the one likely to provoke the least effective opposition-is to impose artificial caps that destroy responsive and functional entitlements.

To be sure, conservatives have not always avoided direct cuts in programs that are still entitlements. PRWORA made many immigrants, substance abusers, and members of other unpopular groups ineligible for several entitlement programs, judging that those groups were sufficiently insular that the political risk of attacking them was slight. Apparently because of some computational errors, House Republicans' proposal to block grant the school meal programs in March 1995 also included substantial funding cuts. ${ }^{326}$ This ignited a feeding frenzy and ultimately forced them to abandon any significant cuts to these programs in the welfare law. ${ }^{327}$ The welfare bills proposed throughout 1995 and 1996 included deep, specific cuts in food stamps. Republicans protected themselves against sharp criticism here, however, by holding the responsive entitlement to food stamps hostage: They made it clear that, if criticism of their cuts ever became too intense, they would simply convert the program to a block grant. Even at that, the House Republicans' 1995 welfare bill sought to eliminate both the functional and responsive entitlements to food stamps by freezing benefit levels and capping total program spending. ${ }^{328}$ The food stamp reductions ultimately enacted focused on areas where the program's functional entitlement was weakest-and hence the impact of the cuts was most difficult to describe except relative to the baseline. ${ }^{329}$ More commonly, however, contemporary conservative

324. See Elizabeth Garrett, Harnessing Politics: The Dynamics of Offset Requirements in the Tax Legislative Process, 65 U. Chi. L. Rev. 501, 543 (1998) (stating that "PAYGO" rules and other provisions intensified conflicts between interest groups in federal budgeting).

325. Exec. Order No. 12,857, 58 Fed. Reg. 42,181 (Aug. 4, 1993). Under this procedure, the Administration must consider cuts in programs whose spending exceeds predictions for reasons that cannot be explained on one of a handful of accepted bases. The impact of this procedure, too, remains to be tested.

326. See, e.g., 141 Cong. Rec. 8506 (daily ed. Mar. 21, 1995) (statement of Rep. Richardson) (arguing that "many of the increases [Republicans said their block grants provided] were written on committee worksheets, not in the proposed legislation").

327. Sec supra note 275 .

328. H.R. 4, 104th Cong. § 1062 (1995).

329. For example, PRWORA froze the food stamp standard deduction-a crude cstimatc of certain average living costs set almost two decades earlier-at $\$ 134$. Personal 
critics of low-income programs have preferred to apply downward pressure on those programs' spending in general, rather than face the political risks of proposing specific cuts that would preserve responsive and functional entitlements, albeit on narrower terms. ${ }^{330}$

This strategy makes sense only if one's sole interest is the dismantlement of a program. ${ }^{331}$ As demonstrated in Part II, it causes whatever funds the program retains to be spent inefficiently and undercuts any behavioral incentives the program's conditions seek to create. ${ }^{332}$ It also forgoes the opportunity to try to persuade the public of the demerits of these programs and possibly forge a new political consensus about them.

3. Liberals' Quixotic Approach to Entitlement. - In contrast to their conservative peers, liberals have shown much more diffidence toward entitlements. Sometimes they have defended and sought to expand existing entitlements. On other occasions, they have abandoned or even attacked existing programs' entitlement structures. ${ }^{333}$ And they have routinely sought to establish new programs with hazy functional entitlements and

Responsibility and Work Opportunity Reconciliation Act of 1996 (PRWORA), Pub. L. No. 104-193, $\S 809$ (a), 110 Stat. 2105, 2309-13 (codified as amended at 7 U.S.C. $\$ 2014$ (e) (1) (2000)).

330. The case of the House budget resolution for fiscal year 1999 is instructive. Republicans wanted deep spending cuts to pay for tax cuts. Initially, House Budget Chairman Rep. John Kasich designed a plan that specified where the cuts would be made, eliminating several programs and narrowing the functional entitlements in others. Kasich Budget Proposal Hits Snag, Wash. Post, May 14, 1998, at A5. But "[w]ith moderate Republicans and appropriators of both parties howling that the cuts go too far ...., House [Republican] leaders concluded that the less said about the details of Kasich's new plan, the better." Eric Pianin, Kasich Backs off Demand for Further Budget Cuts, Closing of Two Departments, Wash. Post, May 15, 1998, at A13. Rep. Kasich then proposed a budget resolution requiring the same level of cuts but without any details, and the Republican caucus closed ranks around him. Eric Pianin, Reluctant House Passes Tax-Cutting Budget, Wash. Post, June 6, 1998, at A8.

331. Accordingly, since this approach seems to abandon many conservative principles, one might speculate that some of its appeal is its potential to free up funds from meanstested programs over time for other uses, such as tax cuts. Alternatively, this strategy could be a covert effort to act upon the extreme view that the very existence of means-tested programs, more than any particular features of their design, is morally corrupting. See, e.g., Charles Murray, Losing Ground 227-33 (1984) (advocating the abolition of most major means-tested programs to increase low-income people's incentives to work).

332. This latter deficiency may explain the apparent diffidence toward entitlements that social conservatives such as Robert Rector sometimes express. See Rector, supra note 5 , at 7 .

333. This retreat was not limited to PRWORA. Democrats also heartily embraced the Workforce lnvestment Act of 1998 (WIA), which merged a number of job training programs-some with standards providing meaningful functional entitlements-into a single amorphous block grant whose few standards are readily evaded. Pub. L. No. 105220, 112 Stat. 935 (1998); 53 Cong. Q. Almanac 7-20 (1997) (describing overwhelming Democratic support for WIA in House); Allan Freedman, Vocational Programs Will Be Biggest Hurdle as Conferees Take Up Job Training Bill, 56 Cong. Q. Weekly 1233 (1998) (same in Senate). 
no responsive entitlement. ${ }^{334}$ The reasons for this confusion appear to be several.

First, some felt it unduly dangerous politically to be seen as supporting entitlements. ${ }^{335}$ Although they could have argued that properly framed subjective entitlements provide security that is important to vulnerable families, they feared that security would be equated with a hammock and juxtaposed with work. Similarly, they could have argued that the proper alternative to a (relatively) unconditional entitlement is a system of mutual obligations in the form of a social contract. Although this form appealed to some-Iowa Democratic Senator Tom Harkin won inclusion of a cosmetic provision on "individual responsibility plans" in the final TANF Iegislation ${ }^{336}$ - they made no serious effort to make these plans enforceable against the state, as they were against claimants. ${ }^{337}$ Instead, they largely acquiesced in a system that effectively resembled barter: Claimants had clear obligations but no clear rights. And with the public debate conflating the various types of entitlements, most liberals

334. See, e.g., Lynn A. Curtis, Policy for the New Millennium, in Locked in the Poorhouse 129, 134-40 (Fred R. Harris \& Lynn A. Curtis eds., 1998) (proposing to make Head Start a responsive entitlement but otherwise offering a menu of new and expanded discretionary programs as a response to urban poverty); U.S. Conference of Mayors, Domestic Priorities: Outline of Economic Security Proposal (Jan. 22, 2003), at http:// usmayors.org/71stWinterMeeting/stimulus2_012203.asp (on file with the Columbia Law Review) (recommending tax changes and a series of new and expanded discretionary programs as high domestic priorities). The most striking example of this short-sighted policy is presented by the Balanced Budget Act of 1997, Pub. L. No. 105-33, 111 Stat. 251. Democrats had significant leverage over that legislation because Republicans needed President Clinton's signature to enact their large package of tax cuts. They exercised that leverage to win enactment of new social spending in several areas. The spending they championed, however, was remarkably short-sighted. First, its aggregate amount was a tiny fraction of the amount of tax cuts in the legislation: A single one of the tax cuts-the reduction in the estate tax-cost more than all the spending initiatives combined. Second, all of the Democratic initiatives either expired or were designed to shrink significantly over time. Finally, and most importantly, only one of those initiatives-restoring some legal immigrants' eligibility for SSI and Medicaid-provided a clear functional or responsive entitlement. The others-an increase in the cap on spending for food stamp, employment, and training programs, an arbitrary number of exemptions from the food stamp three-month time limit for some childless adults, a capped (and expiring) fund for local welfare-to-work projects, and the capped SCHIP block grant-all subsequently experienced serious problems typical of capped programs, with substantial funds going unspent due to administrative problems despite indisputable need. See Robert Greenstein, Ctr. on Budget \& Policy Priorities, Looking at the Details of the New Budget Legislation: Social Program Initiatives Decline over Time While Upper-Income Tax Cuts Grow I3-14 (I997), available at http://www.cbpp.org/812bud.htm (on file with the Columbia Law Review) (discussing preference for tax cuts over social spending initiatives in the 1997 budget legislation).

335. See Edelman, supra note II, at 139 (suggesting President Clinton signed a bill replacing AFDC with the TANF block grant to minimize political risk).

336. 42 U.S.C. $\$ 608$ (b) (2000).

337. The result was quite remarkable-a contract of adhesion that nonetheless did not even purport to bind its drafter. 
feared their defense of responsive or positive entitlements could be misconstrued as championing subjective or unconditional entitlements.

Second, liberals' fractured political base has interfered with their development of a single, coherent approach to social welfare programs. In addition to public benefits claimants and their allies, liberals also respond to governors, state legislators, mayors, public employee unions, trade associations of service providers, academics, and others. Articulating a coherent vision broad enough to satisfy all of these groups would strike moderate voters as too far to the left. Therefore, at a time when shrinking government is the consistent message of conservative factions dominating the Republican Party in most of the country and exercising substantial influence on Democrats in many places, liberals have lacked a counter-message. Strengthening a responsive or functional entitlement program may please one element of their constituency, but winning a short-term infusion of cash into a block grant or vaguely defined discretionary program may please others. ${ }^{338}$

Third, the proliferation of new, mostly small, nonentitlement programs may be the result of a kind of political market failure. Creating a new discretionary program-even if funding is dubious-is likely to be the politically cheapest way to win favorable headlines. ${ }^{339}$ Opponents of domestic spending have little reason to block creation of the new program so long as total funding on domestic discretionary programs remains capped: ${ }^{340}$ The new program either will not be funded or will have to build its budget by cutting funds going to other programs. The media's general failure to differentiate between funded and unfunded programs $^{341}$ and the tendency it and the public have to assume that pro-

338. It should be noted that this problem is not merely a function of "pay as you go" rules making it difficult to increase spending on budgetary entitlements. Since the mid1990s, Democrats have expended enormous, and sometimes successful, efforts to increase funding for the hopelessly amorphous Social Services Block Grant (SSBG), a budgetary entitlement. No procedural or jurisdictional barriers would prevent any money made available for SSBG from being applied instead to liberalizing responsive entitlements such as SSI or EITC.

339. The mismatch between the nominal formation of substantive policy and the actual policy that legislators are willing to fund-and public misconceptions about which set of decisions is more important-is hardly limited to public benefits law. For example, although public attention and scholarship treats the appellate courts' decisions as controlling criminal defendants' rights, in fact, state legislators, who may be unsympathetic to some of the appellate courts' decisions, can ration the extent to which defendants can actually realize those rights by underfunding indigent criminal defense. Thus, the legislature may covertly ensure that criminal defendants' positive entitlements do not operate as the responsive entitlements the public widely assumes them to be. William J. Stuntz, The Uneasy Relationship Between Criminal Procedure and Criminal Justice, 107 Yale L.J. 1, 7-12 (1997).

340. 2 U.S.C. $\$ \$ 633(\mathrm{a})(5),(\mathrm{c}),(\mathrm{f}), 900$ (c) (3)-(4), 901 (a) (2000).

341. Indeed, if a discretionary program actually is funded, even partially, it is likely to generate a second round of media coverage. This may lead many people to believe that twice as many programs are being created and twice as much money is being spent than is actually the case. See, e.g., Janet Cawley, Senate Passes $\$ 423$ Million Homeless Bill, Chi. 
grams are designed as functional and responsive entitlements ${ }^{342}$ make these efforts politically rewarding to liberals. lronically, even if net spending on social programs is not being increased, these news accounts are likely to give the public the sense that benefit programs are expanding and lay the foundation for very real cuts in programs that are responsive or functional entitlements.

Finally, some liberals' penchant for creating and supporting a plethora of relatively small programs, rather than focusing on a few major entitlements, seems to spring from an interest in pursuing a covert political strategy that is the mirror image of the one some critics of social programs have pursued: They appear to believe that, by avoiding an explicit public debate, they can manipulate funding decisions over time. Envisioning a far larger role for the state than this country currently accepts, these liberals seem to see each program as a foot in the door that can be exploited to open up a broad new area of public involvement. This strategy abandons the efficiency of entitlements as well as the legitimacy that comes from making forthright moral arguments to expand programs. ${ }^{343}$ 1t also reflects a remarkable degree of optimism. ${ }^{344}$ Even in the heyday of political support for anti-poverty programs, the efficacy-to say nothing of the political legitimacy-of this model of change would have been dubious. As in the case of the covert conservative strategy to eliminate programs by dismantling their entitlement, this covert liberal strategy must tolerate the inefficient use of whatever funds the program has while it is operating without a responsive entitlement. And, as is true of those that would convert entitlements to capped programs, the strategy of creating new capped programs also risks creating confused and undesirable incentives for prospective claimants. ${ }^{345}$

Trib., Apr. 10, 1987, at 1 (treating authorization of appropriations as if it actually provided funds); Dorothy Collin, Spending Bill Goes to Reagan, Chi. Trib., July 3, 1987, at 5 (describing appropriations bill containing funds for same legislation also as making that money available). But see Robert Pear, President Signs $\$ 1$ Billion Bill to Aid Homeless, N.Y. Times, July 24, 1987, at A1 (explaining meticulously the difference between authorizations and appropriations).

342. See supra notes $98-99,101-103$ and accompanying text.

343. See supra note 299 and accompanying text.

344. See, e.g., Peter K. Eisinger, Toward an End to Hunger in America 86, 128-31 (1998) (belittling legislation spending several billion dollars to improve the food stamp program's functional entitlement and to remove eligibility conditions poorly related to need while recommending a range of local pilot projects involving food pantries, community gardens, and investment incentives).

345. See supra Part Il.C. To be sure, many liberals are skeptical of either the desirability or the efficacy of manipulating low-income people's behavior through conditions on benefit programs. See, e.g., Theodore R. Marmor et al., America's Misunderstood Welfare State: Persistent Myths, Enduring Realities 219-22 (1990) (noting that "incentives are not behaviors"). Nonetheless, many policymakers and voters will assume that low-income people follow these incentives and thus lend receptive ears to critics attacks on the programs couched in those terms. 
Today, this model seems wildly naive. To be sure, a few programssuch as WIC and Head Start-that started as pilots have blossomed into widely accepted social policies. Many, many more, however, have been defunded, merged, block granted, or simply condemned to an indefinite half-death as isolated, obscure funding streams protected by the political strength of their current beneficiaries but without any prospects for expansion.

Liberals could not transform the United States into Sweden with a little sleight of hand on the appropriations committees-even if they controlled the appropriations committees. Rather than dividing social spending among tiny programs too numerous and complex to defend, seeking to accomplish goals whose full achievement would require aggregate spending far exceeding anything any President or Congress might plausibly support, liberals would be better advised to accept that social initiatives in this country are, and for the foreseeable future will remain, far more limited than they may prefer. The maintenance of a multiplicity of nonentitlement programs does, however, exacerbate two important factors limiting the public's receptiveness to more social initiatives: the mistaken belief that we already are doing far more than in fact we are ${ }^{346}$ and the sense that public programs work poorly since they have failed to check the widespread social problems liberals cite as justification for more social spending. Finally, the lack of transparency of this approach undermines liberals' credibility in attacking the equally illegitimate conservative strategy of dismantling programs' entitlements while leaving their shells in place. ${ }^{347}$

A more practical approach would be to focus on strengthening the few major programs that could plausibly attain both functional and responsive entitlements without adopting such restrictive eligibility conditions that they must ignore a large portion of those in need. If liberals can show that government programs can effectively assure low-income people access to minimally adequate health care-or nutrition, or housing, or child care-the public is more likely to entrust them with the funds and responsibility to address another social problem. The present system of half-efforts to address this problem and quarter-efforts to address that one is too confusing to inspire much public confidence and too easy for skeptics to dismiss as a sweeping failure.

\section{E. Transparency and Legitimacy in Public Benefit Program Politics}

Just as responsive and functional entitlements are essential to the efficient operation of public benefit programs, those same structures are equally vital to an open and legitimate dialogue about the social role those programs play. Programs governed by complex formulas and caps are all but impossible for most policymakers and voters to understand. As

346. See supra Part III.B.4.

347. See supra Part III.D.2. 
a result, nonentitlement structures largely remove these programs from the realm of informed public debate. This lack of transparency has prevented the public from making informed assessments of the extent of the safety net it is supporting. The obscurity of these questions also has created opportunities for factions on both sides of the political spectrum to pursue covert agendas to expand or dismantle means-tested programs. Whatever the short-term tactical advantages of these strategies, they undermine the effectiveness and efficiency of means-tested programs as well as the legitimacy of any outcome they yield.

\section{CONClusion}

Although much-debated, the economic and political implications of entitlements remain remarkably poorly understood. Allowing the term "entitlement" only symbolic meaning, whether as a harsh epithet or as a proud banner, obscures some important concepts well worth examination. Understanding the behavior of society, which supplies public benefits, and potential claimants, who consume them, as forming a market allows us to bring to bear familiar principles of economic analysis. These techniques reveal that most programs are much more efficiently administered as responsive entitlements-programs that serve all claimants meeting specified eligibility criteria. This is true without regard to how generous a program may be. Manipulating a program's participation through changes in eligibility rules rather than waiting lists or complex priority schemes minimizes administrative costs, better targets available resources on need, and clarifies the program's incentives for current and prospective claimants. 1t also allows the program to respond automatically to changes in the aggregate amount or distribution of need. Defining benefits in terms of the functions we intend them to accomplish can reduce disruption of private markets.

The clarity of entitlement structures also has important political implications. Defining who gets benefits in terms of relatively straightforward eligibility criteria, and what recipients get in terms of what practical purpose the benefit is supposed to help them accomplish, allows a broad range of policymakers and the public to debate the program's proper role. Defining programs in terms of arbitrary participation caps and benefit amounts restricts meaningful participation in debates to an expert few. The lack of transparency of arbitrarily capped programs offers opportunities for extreme groups to pursue covert agendas far out of step with the wishes of most of the electorate. The ease with which nonentitlement programs' scope can be misrepresented for political gain has created perverse incentives to rely upon these economically inefficient program designs.

Broader disagreements about the proper scope of government in our society have resulted in an antipathy for entitlement structures that is neither rational nor wise. This emotional rejection of entitlement structures, rather than assessing each program on its merits, risks losing the 
economic efficiencies and political transparency of having programs controlled by general laws drawn in relatively clear, intelligible terms. In an area of public policy that so clearly defines us as a nation, we can afford neither the waste nor the alienation that this anti-entitlement frenzy has brought. 


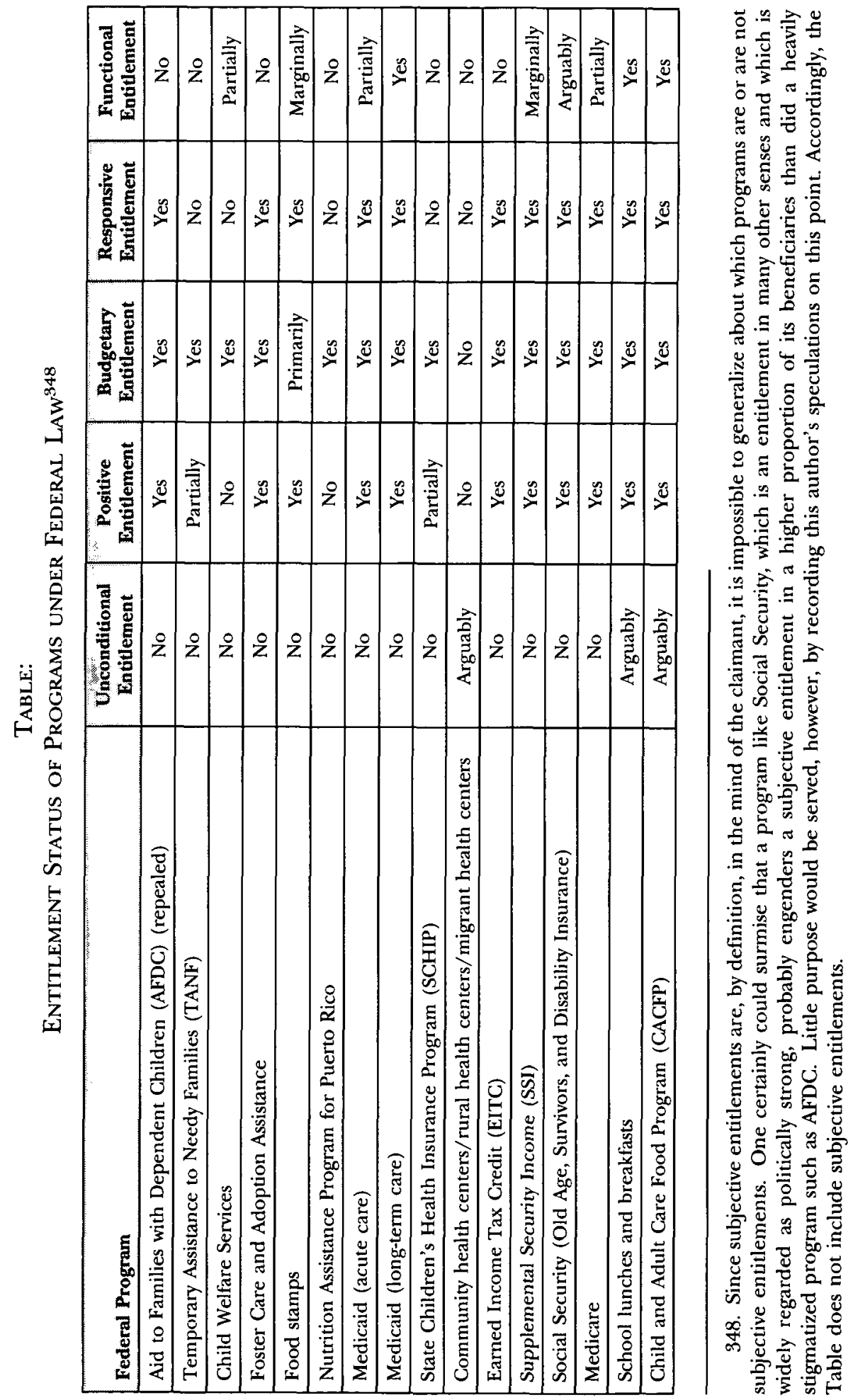




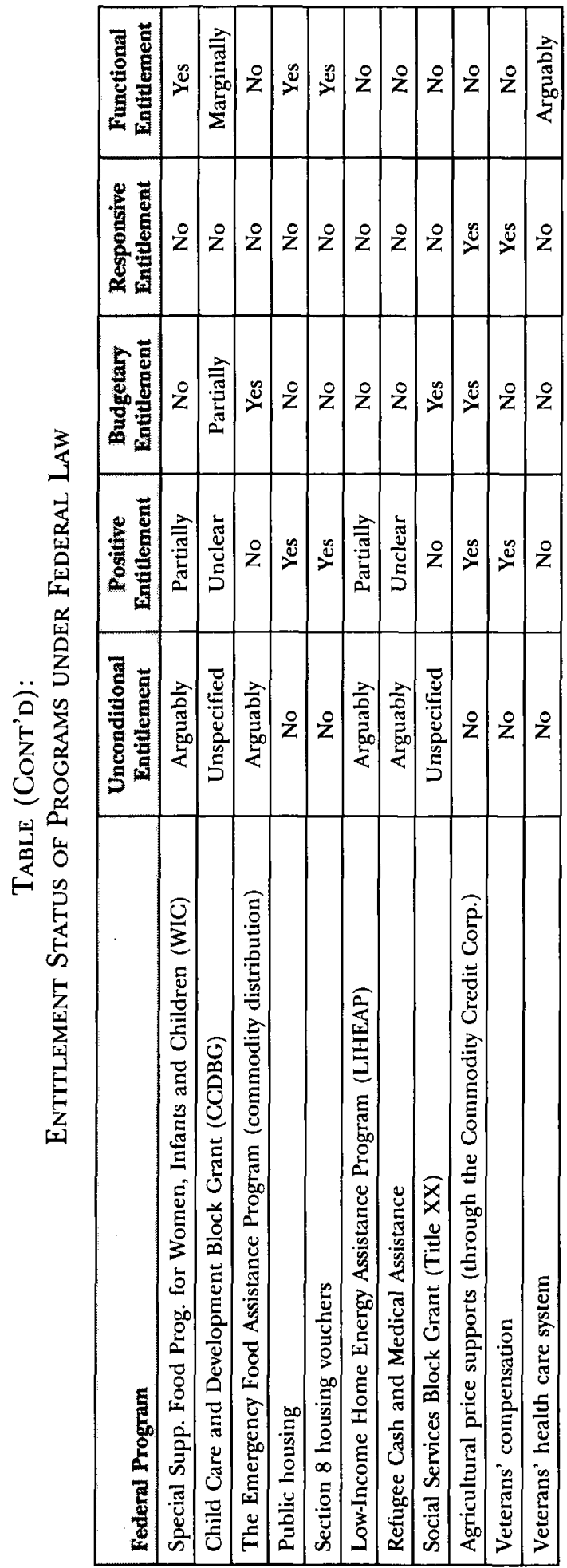

